\title{
Guano-related phosphate-rich minerals in European caves
}

Philippe Audra $^{1 *}$, Jo De Waele ${ }^{2}$, Ilham Bentaleb ${ }^{3}$, Alica Chroňáková ${ }^{4}$, Václav Krištůfek ${ }^{4}$, Ilenia M. D’Angeli ${ }^{2}$, Cristina Carbone ${ }^{5}$, Giuliana Madonia ${ }^{6}$, Marco Vattano ${ }^{6}$, Giovanna Scopelliti $^{6}$, Didier Cailhol ${ }^{7}$, Nathalie Vanara $^{8}$, Marjan Temovski ${ }^{9}$, Jean-Yves Bigot ${ }^{10}$, Jean-Claude Nobécourt ${ }^{11}$, Ermanno Galli1 ${ }^{12}$, Fernando Rul1 ${ }^{13}$, and Aurelio Sanz-Arranz ${ }^{13}$

${ }^{1}$ Polytech'Lab EA 7498, University of Nice Sophia-Antipolis, 930 route des Colles, 06903 Sophia-Antipolis, France

${ }^{2}$ Department of Biological, Geological and Environmental Sciences, University of Bologna, Via Zamboni 67, 40127 Bologna, Italy

${ }^{3}$ Institute des Sciences de l'Évolution Montpellier, University of Montpellier, Montpellier, Cédex 5, France

${ }^{4}$ Biology Centre CAS, Inst. Soil Biology, Na Sadkach 7, 37005 Ceske Budejovice, Czech Republic

${ }^{5}$ DISTAV, Dipartimento di Scienze della Terra, dell'Ambiente e della Vita, Università di Genova, Corso Europa 26, Genova, Italy

${ }^{6}$ Dipartimento di Scienze della Terra e del Mare, University of Palermo, Via Archirafi 22, 90123 Palermo, Italy

${ }^{7}$ Laboratoire EDYTEM, University Savoie - Mont-Blanc, CNRS, Pôle Montagne, 73376 Le Bourget-du-Lac, France

${ }^{8}$ Laboratoire TRACES, UMR 5608 / Université Paris 1 - Panthéon-Sorbonne, France

${ }^{9}$ Isotope Climatology and Environmental Research Centre, Institute of Nuclear Research, Hungarian Academy of Sciences, Bem tér 18/C, 4026 Debrecen, Hungary

${ }^{10}$ Association Française de Karstologie (AFK), 21 rue des Hospices, 34090 Montpellier, France

${ }^{11}$ Crespe, 06140 Vence, France

${ }^{12}$ Università degli Studi di Modena e Reggio Emilia, Dipartimento di Scienze Chimiche e Geologiche, Campus Scientifico, via Giuseppe Campi, 103,

41125 Modena, Italy

${ }^{13}$ Unidad Asociada UVA-CSIC al Centro de Astrobiologia, University of Valladolid, Parque Tecnológico Boecillo, 47151 Valladolid, Spain

Abstract: Guano is a typical deposit found in caves derived from the excretions of bats and in minor cases of birds. These organic deposits decompose and form a series of acid fluids and gases that can interact with the minerals, sediments, and rocks present in the cave. Over sixty phosphates are known and described from caves, but guano decay also often leads to the formation of nitrates and sulfates. In this study twenty-two European caves were investigated for their guano-related secondary minerals. Using various analytical techniques, seventeen phosphates, along with one sulfate (gypsum), were recognized as secondary products of guano decay. Among those minerals, some are very rare and result from the interaction of guano leachates with clays, fluvial deposits, or pyrite. Some of these minerals are even found only in the studied caves (spheniscidite, robertsite). The most common minerals belong to the apatite group. The common mineral association present in fresh decaying guano is brushiteardealite-gypsum, minerals that usually are not present in older deposits because of their higher solubility. Most minerals are in hydrated form because of the wet cave environment; however, some specific dry conditions may favor the presence of dehydrated minerals, such as berlinite, formed during guano combustion. Investigation on the acidity of guano piles shows $\mathrm{pH}$ values as low as 3.5 with an increase of acidity with age and depth. Finally, cave guano deposits should be better studied in the future because of their role in paleoenvironmental and paleoclimatic reconstructions and because it is important to better understand the origin of guano-related minerals, especially the phosphates and sulfates. Among all of the caves studied, Corona 'e sa Craba (Italy) and Domica-Baradla Cave (Slovakia-Hungary) are considered to be outstanding sites with respect to their phosphate mineralogy.

Keywords: $\quad$ secondary cave minerals, phosphates, minerogenesis, limestone caves, bat guano Received 1 February 2019; Revised 7 March 2019; Accepted 7 March 2019

Citation: $\quad$ Audra P., De Waele J., Bentaleb I., Chroňáková A., Krištůfek V., D’Angeli I.M., Carbone C., Madonia G., Vattano M., Scopelliti G., Cailhol D., Vanara N., Temovski M., Bigot J.-Y., Nobécourt J.-C., Galli E., Rull F. and Sanz-Arranz A., 2019. Guano-related phosphate-rich minerals in European caves. International Journal of Speleology, 48 (1), 75-105. Tampa, FL (USA) ISSN 0392-6672 https://doi.org/10.5038/1827-806X.48.1.2252

\section{INTRODUCTION}

Phosphate minerals are commonly found in caves containing guano accumulations from bat colonies (e.g., Martini, 1996; Hill, 1999; Onac \& Vereş, 2003) or in caves which contain a large quantity of bone deposits (Goldberg \& Nathan, 1975; Karkanas et al., 2002). The phosphates result from the interaction between guano-derived leachates with cave bedrock, generally limestone, (calcite) speleothems or cave sediments 
(detrital clay deposits). A review of cave phosphate minerals was first published by Hill \& Forti (1997), reporting a total of fifty-two mineral species. The minerogenetic mechanisms forming cave phosphates are microbial decay, dissolution, double replacement, and redox reactions (Onac \& Forti, 2011b). Around 60 cave phosphate minerals are currently known (Onac $\&$ Forti, 2011a), with five of common occurrence: hydroxylapatite, brushite, ardealite (Schadler, 1932; Pogson et al., 2011), taranakite (Hill \& Forti, 1997), and variscite (Onac et al., 2004). They usually display as crusts, nodules, lenses, and earthy or powdery masses (Onac, 2012). Some cave phosphate minerals are very rare, such as tinsleyite (Marincea et al., 2002), foggite and churchite-(Y) (Onac et al., 2005a), hydroxylellestadite (Onac et al., 2006a), and berlinite (Onac \& White, 2003; Marincea \& Dumitraş, 2005; Onac \& Effenberger, 2007; Sauro et al., 2014). Others have been found only in a limited number of caves around the world, such as vashegyite (Forti et al., 2000), stercorite (Frost \& Palmer, 2011), newberyite (Bridge, 1977; Frost et al., 2011), and crandallite (Kaye, 1959; Frost et al., 2012).

Through microbial activity the breakdown of guano produces strong acids (sulfuric, phosphoric), whereas degradation of bat urea yields nitric and other weak organic acids. All processes contribute to increase acidity toward the base of the guano accumulation, with $\mathrm{pH}$ as low as 2-4 (Martini, 1993; Hill \& Forti, 1997; Martini, 2000; Forti, 2001). Nitrogen and sulfur can also be active above the guano accumulation on the ceiling and walls, through their gaseous phases $\left(\mathrm{NH}_{3}\right.$ and $\mathrm{H}_{2} \mathrm{~S}$, respectively). These gases rise through warm air convections produced by exothermic guano breakdown or by bat colonies, then oxidize, often through microbial mediation, into nitric and sulfuric acids, respectively, and together with $\mathrm{CO}_{2}$ eventually strongly corrode the limestone host rock and calcite speleothems (Hill \& Forti, 1997; Martini, 2000; Audra et al., 2016; Onac, 2019). Contrary to sulfur and nitrogen, phosphorus does not have a gaseous phase at ambient temperature.

With time and increase of guano accumulation depth, organic matter decays, and the organic compounds gradually transform into secondary mineral deposits. The oxidation of organic phosphorous into $\mathrm{PO}_{4}{ }^{3-}$ ion seems to be at least partly driven by microorganisms (Forti, 2001; Chang et al., 2010). Very soluble nitrogen is washed away, as ammonium phosphate $\left(\mathrm{NH}_{4}\right)_{2} \mathrm{HPO}_{4}$ transforms into calcium phosphate $\left(\mathrm{CaHPO}_{4}\right)_{2}$ allowing the ammonium ion $\left(\mathrm{NH}_{4}^{+}\right)$to be carried away, according to the following reaction (Frost \& Palmer, 2011):

$$
\left(\mathrm{NH}_{4}\right)_{2} \mathrm{HPO}_{4}+\mathrm{Ca}^{2+}+2 \mathrm{H}_{2} \mathrm{O} \rightarrow \mathrm{CaHPO}_{4} \cdot 2 \mathrm{H}_{2} \mathrm{O}+2 \mathrm{NH}_{4}^{+}
$$

After nitrogen, easily soluble sulfur, in the form of $\mathrm{H}_{2} \mathrm{SO}_{4}$, produced by sulfo-oxidant bacteria (Yoshimura et al., 1989) is consumed thereby producing gypsum, whereas phosphate $\left(\mathrm{PO}_{4}{ }^{3-}\right)$ and cations $\left(\mathrm{Fe}^{2+}, \mathrm{Fe}^{3+}, \mathrm{Al}^{3+}\right.$, $\mathrm{K}^{+}$) gradually increase by relative enrichment, making the $\mathrm{P} / \mathrm{S}$ and $\mathrm{P} / \mathrm{N}$ ratios increase with depth (and age) of the guano pile (Hill \& Forti, 1997; ShahackGross et al., 2004; Onac, 2012). Within the guano accumulation, sulfuric acid reacts with the bedrock and with speleothems and produces sulfates, mainly gypsum (Hill \& Forti, 1997), whereas the reaction with phosphoric acid produces phosphates (Onac \& Veres, 2003). Both gypsum and phosphates are the only stable compounds in such acidic environment (Pogson et al., 2011). At the base of guano accumulations, after leaching of alkali ions (Onac, 2012), the interaction with limestone bedrock (or calcite speleothems) reduces acidity to a $\mathrm{pH}$ close to 6-7 and produces $\mathrm{Ca}-$ rich stable phosphates such as hydroxylapatite and brushite (Hill \& Forti, 1997). Fluorine ( $\mathrm{F}^{-}$) can easily replace the hydroxyl ion $\left(\mathrm{OH}^{-}\right)$generating almost pure fluorapatite (Onac, 2012). The contact with clay materials allows cation exchange (such as $\mathrm{Fe}^{2+}$, $\mathrm{Fe}^{3+}, \mathrm{Al}^{3+}$, and $\mathrm{K}^{+}$) with production of other phosphate minerals, mainly taranakite and variscite, or less frequent mineral species (see Hill \& Forti, 1997). Deeper in the sediment, still acidic conditions allow the vertical leaching of Mn compounds that form a black accumulation horizon marking the boundary of the phosphatization front with the unaltered sediment (Martini, 1993).

Environmental conditions play a key-role in the formation or inhibition of phosphate minerals (Onac \& Vereş, 2003; Shahack-Gross et al., 2003; Puşcaş et al., 2014). From a Romanian cave study, Onac \& Veress (2003) stated that $\mathrm{pH}$, humidity, alkali content, and $\mathrm{Ca} / \mathrm{P}$ ratio are the major parameters controlling the mineral assemblages. Variscite, taranakite, and brushite are stable under acidic conditions, whereas hydroxylapatite indicates less acidic conditions. In low-humidity conditions (and higher temperature), dehydration occurs, causing new minerals to form (i.e., berlinite). In arid regions with extremely dry conditions, very soluble species may precipitate around guano accumulation through evaporation, producing sylvite and nitrate minerals such as saltpeter (Martini, 1993). On the contrary, in damp places, the complete breakdown of guano at very low $\mathrm{pH}(2-4)$ leads to pure gypsum displayed as candyfloss (Martini, 1993). Therefore, phosphate minerals, combined with stable isotope analyses on guano, can be considered as good proxies of past environmental conditions, at both regional and local scales (Onac et al., 2014).

Gypsum often occurs together with secondary phosphate minerals and can be considered in most cases a by-product of guano decay. This mineral probably always forms because of the interaction of sulfuric acid with the carbonate host rock (often limestone) or with the Ca-rich dripping water, but in humid conditions it is generally dissolved away by seeping waters. Gypsum, and more generally sulfates, are thus mainly found in drier cave conditions in which they can persist (do not go into solution) and where evaporation processes dominate.

This paper reports the mineralogical findings of guano-related minerals (phosphates and sulfates) in a variety of European caves, from Hungary, Slovak Republic, France, Macedonia, and Italy, along with the processes and environmental conditions that control their occurrences. 


\section{METHODS}

Sampling. Samples were taken in separate containers or plastic bags, scraping or scratching from the walls or rocks with a chisel, or collecting enough material with a clean spatula. In some cases, physical environmental parameters, temperature (T), relative humidity $(\mathrm{RH})$ and $\mathrm{CO}_{2}$ concentration were measured using a pSENSE RH from SENSEAIR AB, with a precision of $\pm 0.6^{\circ} \mathrm{C}, \pm 3-5 \% \mathrm{RH}, \pm 30 \mathrm{ppm} \mathrm{CO}_{2}$.

pH. The $\mathrm{pH}$ of guano deposits was determined using a $\mathrm{pH}$ meter in a 1:5 proportional guano: distilled water suspension.

X-ray diffraction. Samples were analyzed on different diffractometers: a Philips PW 1050/25 (40 kV and $20 \mathrm{~mA}$, CuKa radiation, Ni filter) at the University of Modena and Reggio Emilia, Italy; a Philips (40 kV and $20 \mathrm{~mA}$, CoKa radiation, Graphite filter) at the CEREGE - CNRS, Aix-Marseille University, France; a Philips PW3710 $(40 \mathrm{kV}$ and $20 \mathrm{~mA}$, CoKa radiation, Fe filter) interfaced with Philips High Score software package for data acquisition and processing at the DISTAV (Genoa University); a Bruker Analytical X-Ray System, D8 Endeavor (50 kV and $40 \mathrm{~mA}$, CuKa radiation, Ni filter) at the University of South Florida; and a Panalytical Xpert Pro $(60 \mathrm{kV}$ and $200 \mathrm{~mA}, \mathrm{Cu}$ $\mathrm{Ka}$ radiation) at CINaM - CNRS and Aix-Marseille University. All samples were scanned from $5^{\circ}$ to $75^{\circ}$ $2 \theta$ with a step increment of $0.02^{\circ}$, a scan speed of $0.5 \mathrm{~s} / \mathrm{step}$. Mineral identification and abundance were evaluated semi-quantitatively by determining peak intensities (peak height) of the X-ray diffraction results with the DIFFRAC ${ }^{\text {Plus }}$ EVA V.8.0 software and compared to the ICDD-PDF2 database for phase identification.

${ }^{14} \mathrm{C}$ radiometric dating. Sixteen bat guano samples and a piece of wood found at the base of the Raganeous guano heap were radiocarbon dated by means of accelerator mass spectrometry (AMS) in the Poznań Laboratory (Poland). Additionally, thirteen other bat guano samples were dated by the ARTEMIS Radiocarbon Laboratory Facility (LMC14, Saclay France) and one sample was dated at the Centre de Datation de Radiocarbone (CDRC) in Lyon (France). Radiocarbon calibrated ages were obtained using the online program CALIB 7.10 (Stuiver and Reimer, 1993) with the IntCal13 atmospheric calibration

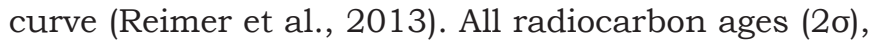
including those from previous studies, are reported in calibrated years as cal yr. AD and BC. In addition, we used 6 results from previous studies (Krištůfek et al., 2008).

Micro-Raman spectroscopy. Since XRD spectra are sometimes less relevant for certain phosphate minerals, further information was obtained from micro-Raman spectroscopy. These analyses were carried out at the Unidad Asociada UVA-CSIC at the Centro de Astrobiologia, University of Valladolid (Valladolid, Spain). Up to 11 Raman spectra were taken from different areas of each sample. The excitation source was a Laser Research Electro-Optics (REO) working at $632.8 \mathrm{~nm}$. The KOSI HoloSpec f/ 1.8i spectrometer from Kaiser Optical covered a spectral range of $150-3,800 \mathrm{~cm}^{-1}$ and a spectral resolution of $5 \mathrm{~cm}^{-1}$, while the CCD (charge coupled device) employed was a DV420A-OE-130 model from Andor. The Raman head used was KOSI MKII, HFPHFC-S-632.8 model from Kaiser Optical Systems coupled by optical fiber to a Nikon Eclipse E600 microscope, which in turn, was attached to a JVC TKC1381EG video camera for visual analysis and precise control of the measured spots. An objective of $50 \times$ allowed microanalyses of $15 \mu \mathrm{m}$ diameter spots. The laser power on the sample was maintained around $15 \mathrm{~mW}$ (corresponding irradiance of $76 \mathrm{~kW} / \mathrm{cm}^{2}$ ) to ensure no thermal damage occurred to the samples. Typical integration time for spectral acquisition was $10 \mathrm{~s}$ and 10 accumulations were done. The sample was manually scanned, whereas the height of focus adjusted in order to optimize the intensity of the spectra signals.

In Isturitz Cave, an in-situ mineral characterization was carried out by the Departamento de Quimica Analitica, Universidad del País Vasco, using a portable Raman spectrometer innoRam (B \& WTEKINC., Newark, USA), equipped with a $785 \mathrm{~nm}$ excitation laser (with $225 \mathrm{~mW}$ of nominal power), with a measurement area of about $100 \mu \mathrm{m}$. The Raman signals are collected by a refrigerated CCD detector using the Peltier effect. The spectrometer allows analyzing a fixed spectral range between 100 and $3,500 \mathrm{~cm}^{-1}$, with an average spectral resolution of $3 \mathrm{~cm}^{-1}$. Twenty measures by point were taken for representativity of the analysis. Spectra were produced using BWSpecTM v.4.02_15 (B \& WTEKINC., Newark, USA) and data processed using Omnic 7.2 (Nicolet).

Scanning electron microscopy (SEM). Scanning electron microprobe analyses were performed with a SEM VEGA3 TESCAN (DISTAV, Genoa University) operated at $20 \mathrm{kV}$ and equipped with the EDAXAPOLLO_X DPP3 energy-dispersive (EDS) X-ray spectrometer having an ultrathin polymer window and with resolutions for Manganese $\mathrm{Ka}=126 \mathrm{eV}$ and typically ranging detection for chemical elements of atomic number greater than 5 (Boron). Data acquisition and elaboration were performed with the TEAM Enhanced Version: V4.2.2 EDS software. Qualitative chemical analyses were also carried out on a Philips XL40 environmental scanning electron microscope (ESEM) equipped with an energy dispersive spectrometer (EDS-EDAX 9900) at the C.I.G.S. (Centro Interdipartimentale Grandi Strumenti) of the Modena and Reggio Emilia University.

Subsequently, elemental characterization by Energy Dispersive X-ray Fluorescence (EDXRF) was carried out using XMET5100 (Oxford Instruments), equipped with a Rhodium $\mathrm{X}$-ray tube having a maximum voltage of $45 \mathrm{kV}$ and a high-resolution silicon detector (SDD) with a spectral resolution of $20 \mathrm{eV}$ and an energy resolution of $150 \mathrm{eV}$ (measured with the $\mathrm{K}$-alpha transition of manganese at $-20^{\circ} \mathrm{C}$ ). Each point was measured at least three times. Some samples of the Grotta dei Personaggi and Salnitro cave (Sicily) were analyzed with a SEM LEO 440 equipped with a EDS Oxford ISIS system with a Si (Li) PENTAFET detector (DiSTeM, Palermo University). 


\section{CAVES AND SAMPLING SITES DESCRIPTION}

We studied 22 caves systems in Europe where guano deposits and bat colonies are or were present: one on the border between the Slovak Republic and Hungary, seven in France, three in Macedonia, and the remaining eleven in Italy (eight of which on the island of Sicily).

\section{Domica-Baradla (Kečovo, Slovakia and Aggetlek, Jósvafö, Hungary)}

The Domica-Baradla cave system contains $21 \mathrm{~km}$ of passages developing across the Slovakian and Hungarian border (Fig. 1). It has been included in the UNESCO World Heritage List since 1995. Domica Cave has its main entrance at $339 \mathrm{~m}$ asl, whereas the mountains range from 180 to $947 \mathrm{~m}$ asl (Gallay et al., 2015). The cave is formed in the Middle Triassic (Ladinian) lagoon limestones of Wetterstein type (Gaál \& Vlček, 2011). The main cave displays large passages of up to $25 \mathrm{~m}$ diameter. It is fed by multiple sinking rivers that bring sediments (mainly clay) from outside. Cosmogenic (Al-Be) nuclide dating (3.47 \pm $0.78 \mathrm{Ma}$ ) of the oldest gravels in the upper level shows that the cave originated in or before middle Pliocene (Bella et al., 2019). Relative humidity ranges from 95 to $98 \%$, and temperature from 10.2 to $11.4^{\circ} \mathrm{C}$, placing the cave among the warmest in Slovakia according to its latitude and altitude (Bella \& Lalkovič, 2001). The partial pressure of $\mathrm{CO}_{2}$ of the cave air is $1700-1800$ ppm (July 2015). Vegetation above the cave comprises shrub and deciduous forest. The cave is equipped for tourist visits with $1.6 \mathrm{~km}$ of foot trails and it attracts 30,000 visitors per year.

Past records of bat species mention the presence of Rhinolophus hipposideros, R. euryale, Plecotus auritus, Myotis myotis, M. emarginatus, $M$. natterei, and Eptesicus discolor (Kettner, 1948). Currently, a colony of up to 1,500-2,500 individuals of Mediterranean horseshoe bats ( $R$. euryale) use Domica Cave during their pre-hibernation stage (Kováč et al., 2014). Due to the large extension and dimension of passages, bats are settling up to more than $1 \mathrm{~km}$ away from the closest entrance. Many guano deposits are present as small accumulations from individual bats, or as large guano heaps. Some cone-shaped heaps are actively accumulating such as in Prales Chamber or in Palmový háj, which basal radiocarbon date is at about AD 990 (Krištůfek et al., 2008). Other guano accumulations are not active anymore such as in Libanon-hegy in Baradla Cave. Previous phosphate studies mention the occurrence of gypsum, brushite, and "apatite" (Kettner, 1948). The soluble brushite, associated to rims of calcite, deposited as wall crusts from leachates through above-lying guano deposits only when dry conditions were present. Gypsum, associated with brushite was identified at the base of guano piles, in guano pots (small depressions on the cave floor created by guano and its acids), and at the top of large stalagmites that collected bat droppings. In Palmovy háj, Kereskényi (2014) identified brushite and traces of ardealite at the guano surface, and taranakite, gypsum, and hydroxylapatite at depth. In Baradla Cave, the same author identified hydroxylapatite and taranakite.

The following three sites were sampled: in Prales Chamber (Fig. 1A), close to the show cave entrance of Domica, guano corrosion pots on top of some stalagmites originating from guano drops of individual bats were found to contain some secondary mineral deposits (Fig. 2A). Below the fresh guano, we sampled a whitish-yellowish paste (Sample Pr. B) covering weathered limestone (Pr. A). In Teknösbéka (Turtle Gallery; Fig. 1B), close to the show cave entrance of Baradla, ceiling cupolas are covered with patches of dark brown crusts (BA 3 in Fig. 2B). Libanon-Hegy is a chamber located at about $1.5 \mathrm{~km}$ from Baradla Cave entrance (Fig. 1C), where we found some recent guano deposits. The BA 4 guano accumulation is old and no longer active; it displays a dark brown compact and sticky material, about $50 \mathrm{~cm}$ thick (Fig. 2C). Here we sampled a white pasty wet layer (BA 4a), another white layer located above clay (BA 4b), a sticky black layer at the contact of the limestone base (BA 4c), and a wet pasty pure white deposit also at the contact with the limestone base (BA 4d) at $5 \mathrm{~cm}$ above the base of the guano deposit.

\section{Julio Cave (Saint-Étienne-d'Albagnan, Hérault, France)}

Julio Cave is located in the Montagne Noire, a southern segment of the French Massif Central. The cave opens along the Jaur Valley, at $205 \mathrm{~m}$ asl. It is a several hundred meters long maze, developed along a steep dip (about $60^{\circ}$ ) of the Lower Devonian limestone (Fig. 3). The lower levels contain large cobbles introduced by the Jaur River. Decantation silts and fine sands are present up to the top of the cave, $73 \mathrm{~m}$ above the entrance. They contain abundant allogenic minerals (quartz, mica, feldspars) from past flooding events. The cave was mined for guano in the early $20^{\text {th }}$ century. A recent study regarding important bat colonies mentions Miniopterus schreibersii $(3,000$ individuals), Rhinolophus euryale (800 individuals), Myotis capaccinii, and $R$. ferrumequinum (Nemoz, 2008). The cave is included in a Natura 2000 protected area. In its upper part, old and fresh guano cover the silty-sandy sediments that are entirely weathered to a grey or white toothpaste-like material. We sampled the lower grey layer (Vezelle 3) and the upper white one (Vezelle 2).

\section{Isturitz-Oxocelhaya Caves (Isturitz and Saint- Martin-d'Arberoue, Pyrénées-Atlantiques, France)}

The Isturitz-Oxocelhaya caves are located on the NW piedmont of the Pyrenees Range. The Gatzelu Hill (209 m asl) is built of Lower Cretaceous (Aptian) limestones surrounded by marls and appearing as a rocky spur blocking the Arberoue Valley. The homonymous river crossed the Gatzelu Hill forming through-caves and leaving fluvial sediments within them. Four tiers are arranged over an altitudinal range of $75 \mathrm{~m}$, the lowest one still active (Fig. 4). The caves were once intensively used as shelters by animals, mainly bears and bats, and by humans since the Middle Paleolithic, 

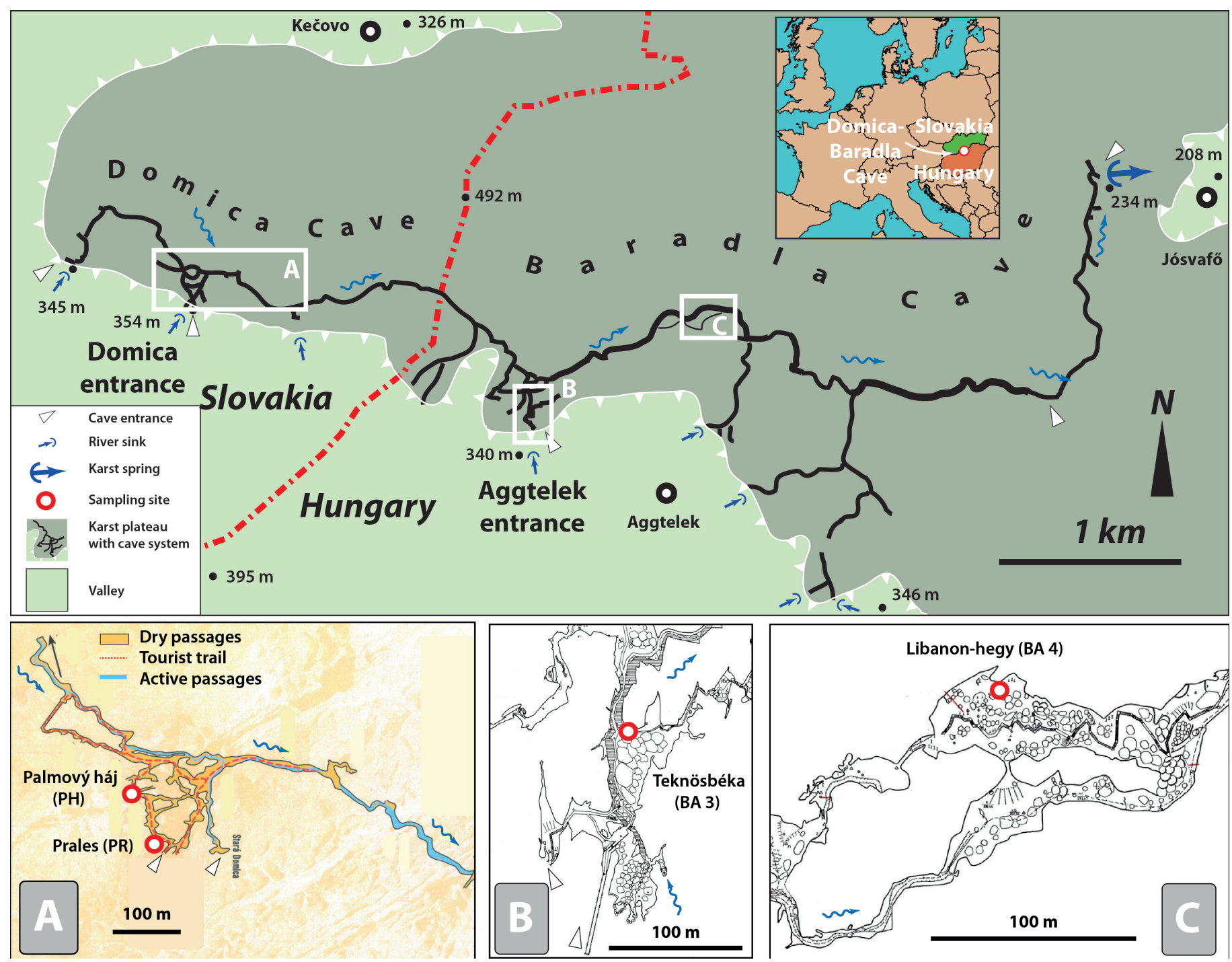

Fig. 1. Plan view of Domica-Baradla cave system in Slovakia and Hungary, with location (A-C) of studied places (redrawn after Ország et al., 1989). Detailed survey of Domica Cave after Slovak Cave Association (http://www.ssj.sk/en/jaskyna/7-domica-cave) and of Baradla Cave after Ország et al. (1989).

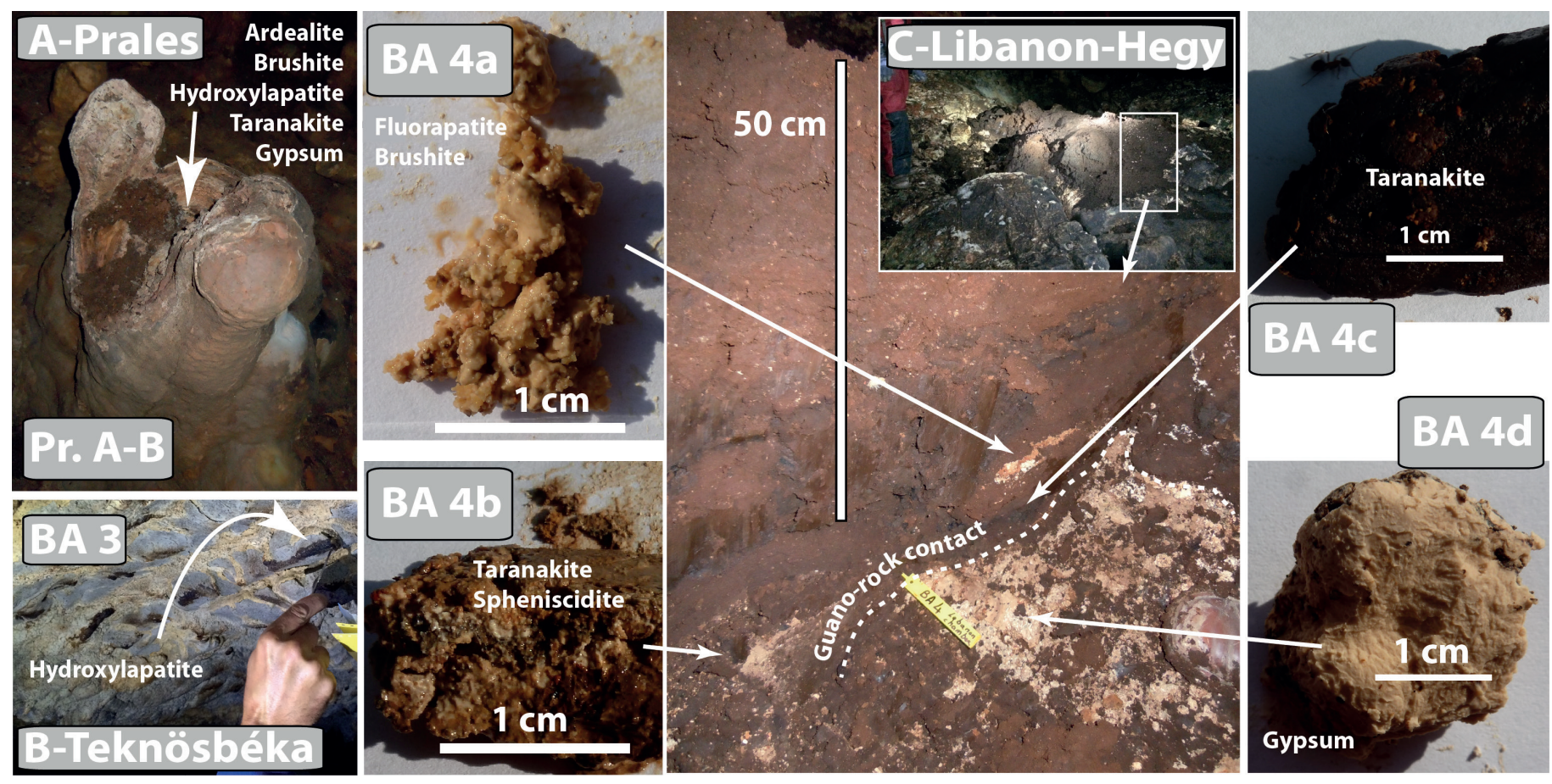

Fig. 2. Samples in Domica-Baradla Cave. A) Prales Chamber in Domica Cave. Guano-corroded stalagmite showing calcite layers in the guano pot that perforates its upper part. Below the guano, a whitish-yellowish paste (Pr. B) covering weathered limestone (Pr. A) was sampled (photo by V. Krištůfek); B) Teknösbéka (Turtle Gallery) in Baradla Cave. Dark brown apatite crusts (BA 3) on the ceiling of a cupola (Photo by A. Chroňáková); C) The guano accumulation in Libanon-Hegy, Baradla Cave (Photo by V. Krištůfek) with the location and mineralogy of BA 4 samples (Photos by P. Audra). 
as shown by major art testimonies such as paintings and engravings (Garate et al., 2013). Also, guano and phosphates were intensively mined during the second half of the $19^{\text {th }}$ century. After being classified as a Historical Monument in 1953 and opened as a show cave, all its entrances were closed. Consequently, bat colonies (mainly Myotis myotis) disappeared. Currently, only a couple of bats are still present (Rhinolophus hipposideros, R. ferrumequinum).

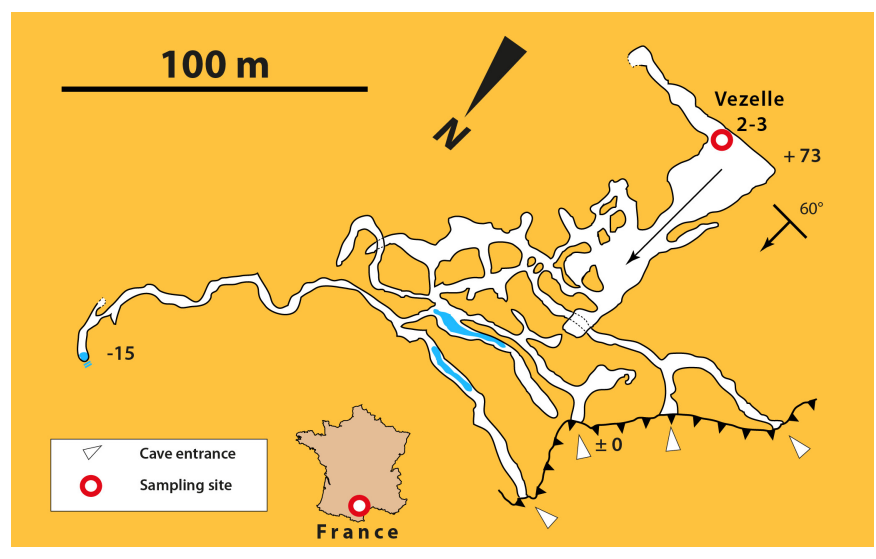

Fig. 3. Plan view of the Julio Cave with sampling-site locations (Survey after J. Fauré, SC Béziers, 1981, redrawn).

Four sites were investigated in-situ using portable Raman spectrometer and XRF (Figs. 4-5). An artificial tunnel allows the connection of the Isturitz upper level with the Oxocelhaya middle level. Before the tunnel enters the host rock it cuts and displays the entire sediment filling of Isturitz Cave along the staircase ("Staircase" sample, Fig. 5A). The lower part of the sediment filling resting on the rocky floor consists of fine colored sands (yellow, orange) separated by a dark layer. The floor of the Rhinolophes Chamber, located in Isturitz Cave, is covered by boulders. Boulders are partly covered by white crusts ("Rhinolophes" sample, Fig. 5B). Below these crusts, the limestone rock is weathered and has a powdery appearance. The "Great Pilar" is a huge calcite column, deeply corroded by condensation niches linked to aerial corrosion above guano (Audra et al., 2016). We analyzed dark crusts and corroded white surfaces ("Great Pilar" sample, Fig. 5C). At the Lithophone site, a guano corrosion pot (depression formed by acid guano corrosion) is covered by fresh guano and white deposits ("Lithophone" sample, Fig. 5D).

\section{Raganeous Cave (Saint-Benoît, Alpes-de-Haute- Provence, France)}

Raganeous Cave opens in a cliff along the Coulomp Valley at $698 \mathrm{~m}$ asl in the Southern French Alps. Together with neighboring Radar and Théoriciens caves, they constitute a system of maximal altitude difference of $54 \mathrm{~m}$ and of more than $1 \mathrm{~km}$ of mainly large galleries (Fig. 6). The cave is developed in a 30$50 \mathrm{~m}$-thick, steeply dipping $\left(30-70^{\circ}\right)$, fossiliferous (Nummulites sp.) limestone bed, resting on Cretaceous marls and partly covered by Upper Eocene (Priabonian) marls. The cave was an important underground drain, which developed as a phreatic lift in a per ascensum way, following the Pliocene aggradation in Coulomp Valley; the current entrances acted as springs (Mocochain et al., 2011). Underground flow carried fine sandy-clayey sediments into the cave, having originated from the weathering of Priabonian marls and Annot sandstones that were brought in through sinkholes. The caves were "discovered" by climbers in 2012. However, artifacts of Neolithic and Middle Age show that the cave was known and used for over millennia by local inhabitants. Currently, a colony of $>1000$ bats uses the cave for reproduction, roosting, transit, and hibernation. Seven species are present (Rhinolophus ferrumequinum, $R$. hipposideros, R. euryale, Miniopterus schreibersii, Myotis blythii, $M$. myotis, and $M$. emarginatus) (obs. M.-Cl. Lankester).

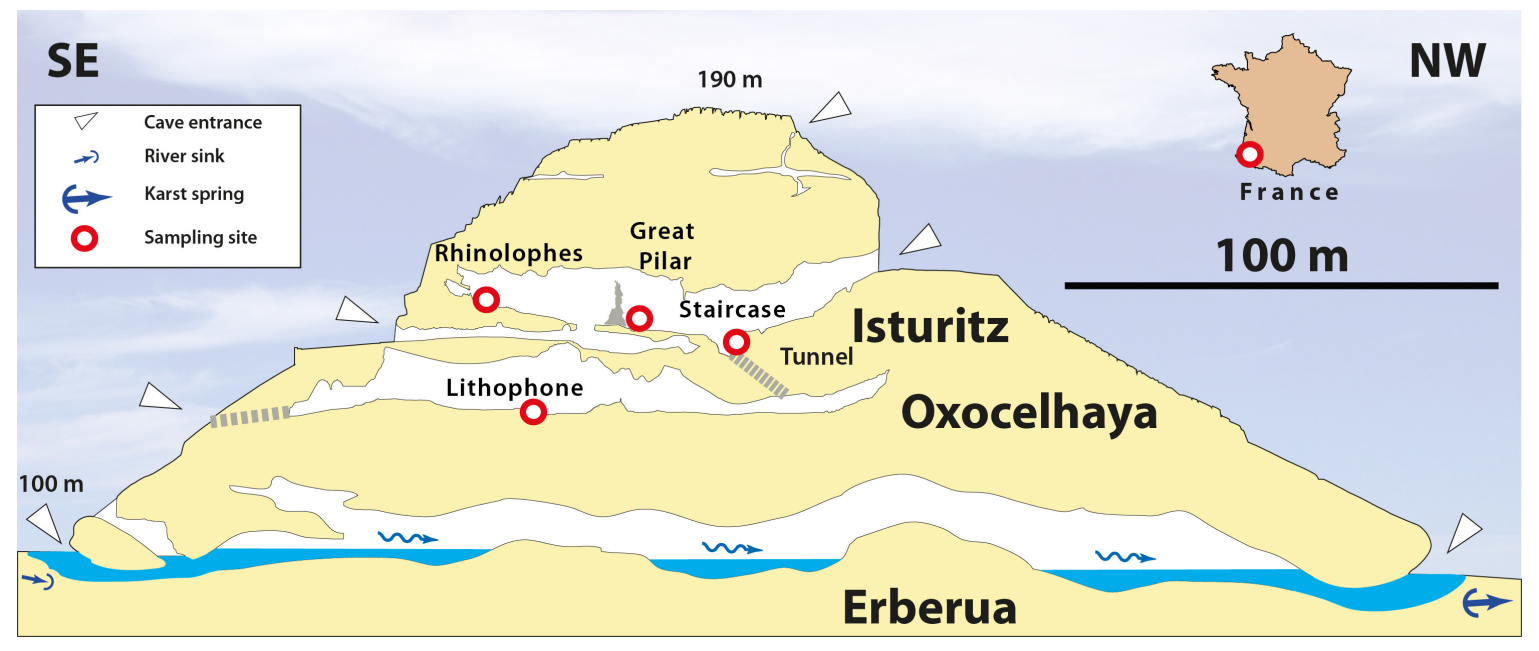

Fig. 4. Profile of Isturitz-Oxocelhaya caves with location of the sampling sites (survey after J.-D. Larribau \& Y. Bramoullé). Horizontal passages correspond to successive-lowering river levels, which were utilized by prehistoric people and bats after each passage drained.

Guano deposits are important in different places. Some are still active and occur as soft accumulations of dry pellets, whereas other deposits are older and appear as dark sticky layers. Two sites were sampled (Fig. 6A). A $1.8 \mathrm{~m}$-high cone is made of dry and poorly compacted material, which is composed of loose guano pellets showing alternating brown-white layers (Raga, Fig. 6B). White and brown layers have been sampled for mineralogy both on top and at the base of the guano cone. Additionally, 10 samples of guano were collected for radiocarbon dating, along with an old wooden torch found close to the bottom of the guano cone. The cave 


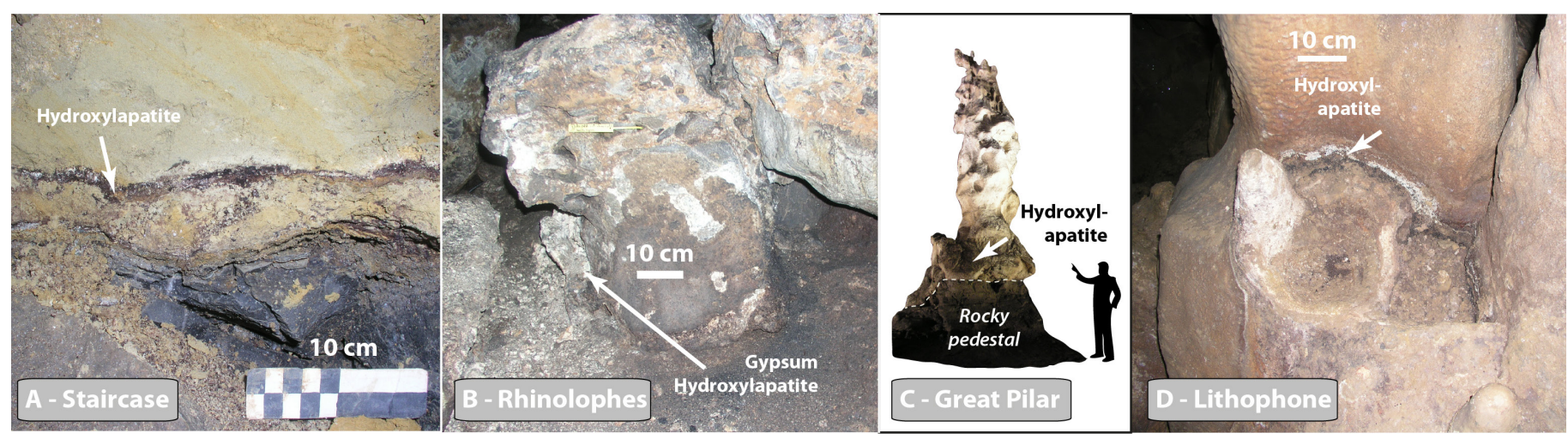

Fig. 5. Studied sites in the Isturitz-Oxocelhaya caves. A) Staircase profile corresponding to the base of the Isturitz Cave filling. Above the rocky floor, layers of yellow and orange stratified fine sands are separated by a dark layer; B) Rhinolophes Chamber. Blocks covered with dark crusts and thick detaching white crusts; C) The Great Pilar. Its surface is either bare, light-colored calcite or it is covered with dark deposits; D) Lithophone site. Guano corrosion pot showing an aureole of soft white material at the contact with the calcite (Photos by J.-Y. Bigot).
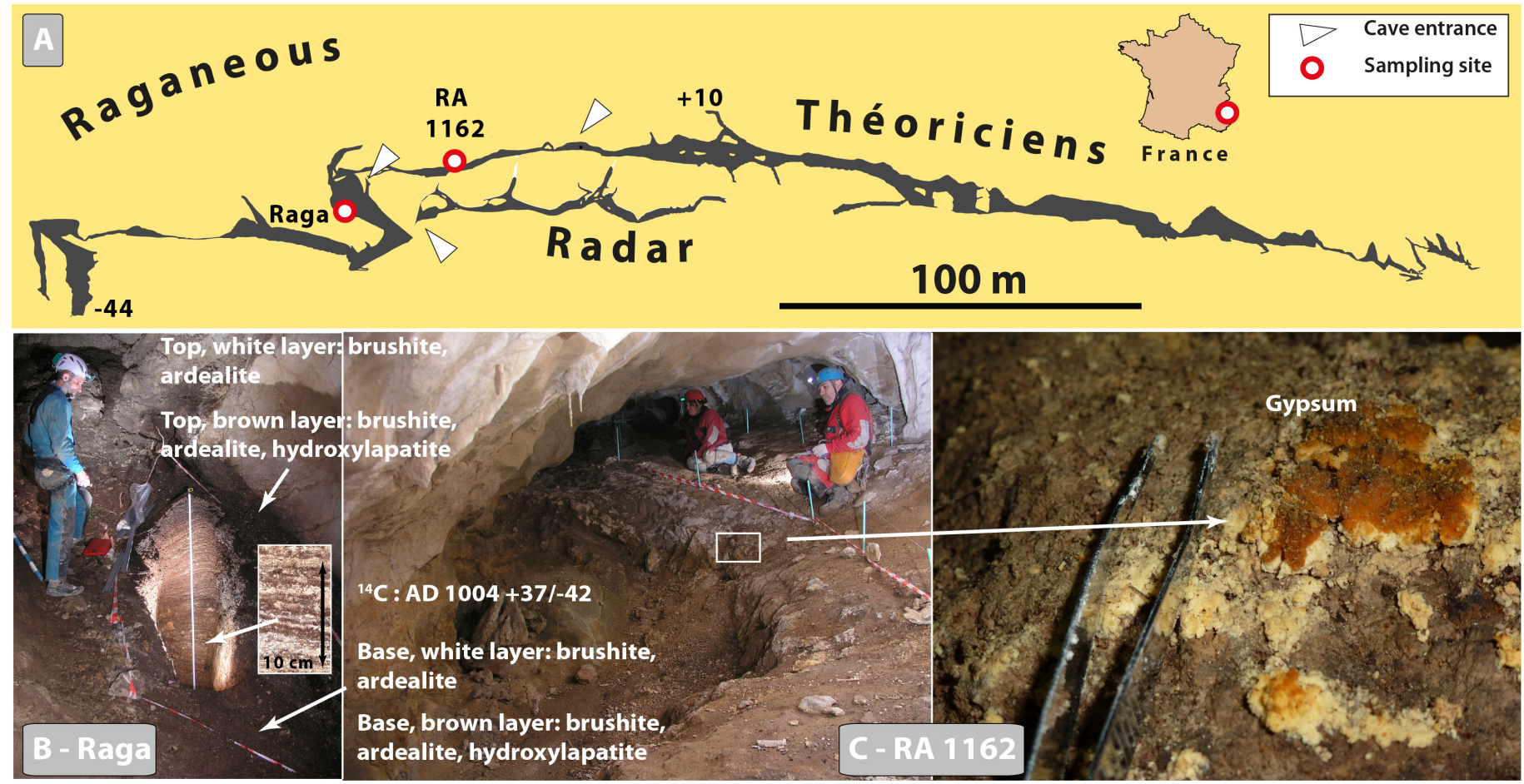

Fig. 6. A.) Profile view of the Raganeous Cave and the neighboring cave systems indicating the sampling sites (Survey: Ph. Audra). B) The $1.8 \mathrm{~m}$ guano profile (Raga). It displays a laminated deposit made of alternating brown and white layers (photo by J.-Y. Bigot); C) yellow-orange crust (RA 1162) covering old guano and clay-sand sediments (photos by J.-Y. Bigot and Ph. Audra).

was probably entirely mined for fertilizers at the time when the torch was abandoned; the present cone built up since the mining days. In the main gallery, clay-sand sediments are covered by old guano, which in turn is veneered by a yellow-orange crust (RA 1162) (Fig. 6C).

\section{Guano Cave (Saint-Cézaire, Alpes-Maritimes, France)}

The Guano Cave opens at the foot of the cliff in the Siagne Gorge, $350 \mathrm{~m}$ asl, in Alpes-Maritimes, France. It is developed in dolomitic and calcareous BajocianBathonian carbonates. The 280 m-long horizontal looping passage harbors numerous features of extreme corrosion, such as corroded blocks, ceiling cupolas, potholes, and weathered walls. Extensive guano deposits were mined by the owner of the cave. A large bat colony (300 individuals) uses the cave for reproduction. Seven species are present (Rhinolophus ferrumequinum, $R$. hipposideros, $R$. euryale, Miniopterus schreibersii, Myotis blythii, M. myotis, and M. capaccinii). The cave is protected for this specific biotope. About $100 \mathrm{~m}$ from the entrance, a narrow passage isolates the inner part, which is characterized by stable climatic conditions ( $\mathrm{RH} 100 \%, 15^{\circ} \mathrm{C}$ ). Old and fresh guano are present in a lateral chamber (Fig. 7), covering a thick red clay deposit (rich in quartz and muscovite grains), originating from erosion of "terra rossa" at the surface, which then was brought in during an early phreatic phase. We sampled a crust between guano and clay (Gua 1b). The dolomitic walls are highly weathered and covered by a $5 \mathrm{~mm}$-thick white paste (Gua 2).

\section{Saint-Marcel Cave (Bidon, Ardèche, France)}

Saint-Marcel Cave opens on the left bank of the scenic 200 m-deep Ardèche Canyon that cuts through a Cretaceous limestone plateau covered by Mediterranean scrub ("garrigue"). The cave is 57 $\mathrm{km}$ long, including $18 \mathrm{~km}$ of underwater passages, has a total relief of $238 \mathrm{~m}(-101 /+137)$, and consists mainly of large horizontal passages disposed in levels (Brunet et al., 2008; Fig. 8A-B). The cave has drained 
the plateau and sinkholes along the Ardèche Gorge since Miocene times (Mocochain et al., 2006, 2011). Temperature in the cave is about $14^{\circ} \mathrm{C}, \mathrm{RH}$ is generally close to saturation, and $\mathrm{CO}_{2}$ varies seasonally from 0.1 to $3-4 \%$ in some places. The cave was used since Middle Paleolithic; today part of the cave is opened for tourism. A colony of about 1,000 individuals of Rhinolophus euryale was present in the 1950s. In the Galerie des Chauves-souris ("Bats Passage"), guano on the surface yielded a ${ }^{14} \mathrm{C}$ age of $1916 \mathrm{BC}$ (Dodelin, pers. comm.). The guano accumulations (maximum thickness of $50 \mathrm{~cm}$ ) extend along this passage, covering a surface of $\sim 15 \mathrm{~m}^{2}$. It occurs as black sticky material, poorly layered, resting on older clay deposits. We sampled pale yellow crystals (SM $2 \mathrm{~b}$ ) on the guano surface (Fig. 8C).

\section{Grosse Marguerite Cave (Aiguèze, Gard, France)}

Grosse Marguerite Cave is located about $4 \mathrm{~km}$ upstream of Saint-Marcel Cave at an altitude of $200 \mathrm{~m}$ asl, on the right bank of the Lower Ardèche Gorge. It opens on a ledge below the top of the cliff, about $115 \mathrm{~m}$ above the Ardèche River. The cave corresponds to an ancient passage of an underground flow, now

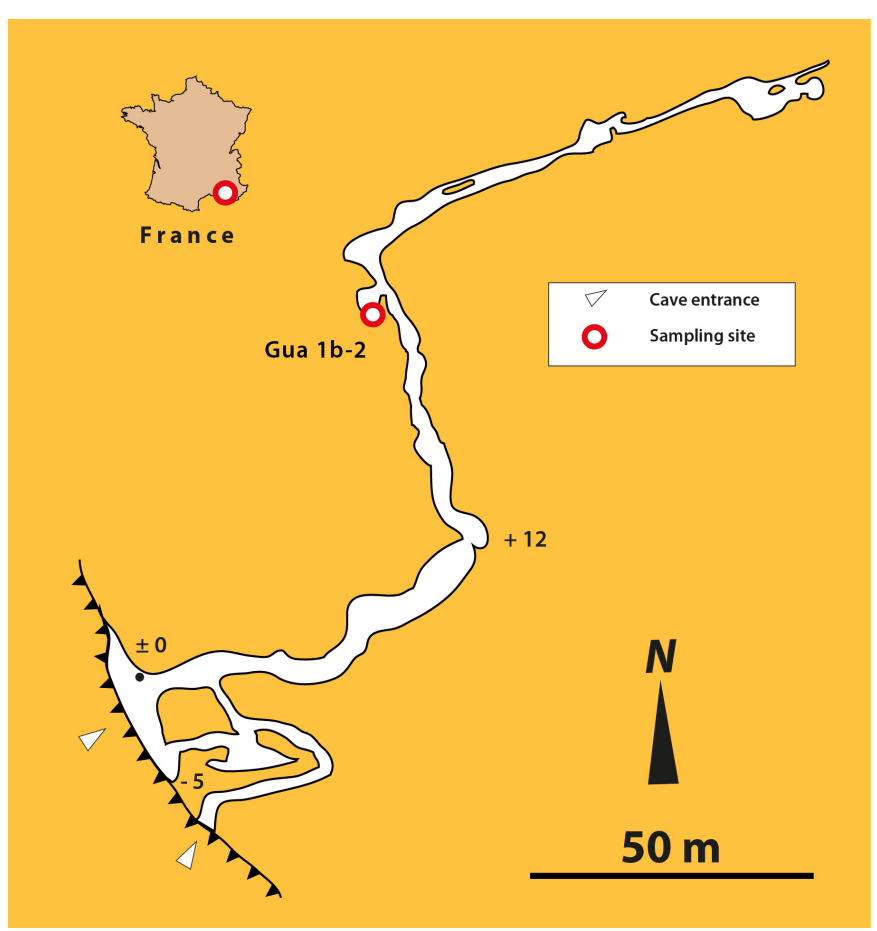

Fig. 7. Plan view of the Guano Cave, located in Provence, France (Survey after Créac'h 1967).

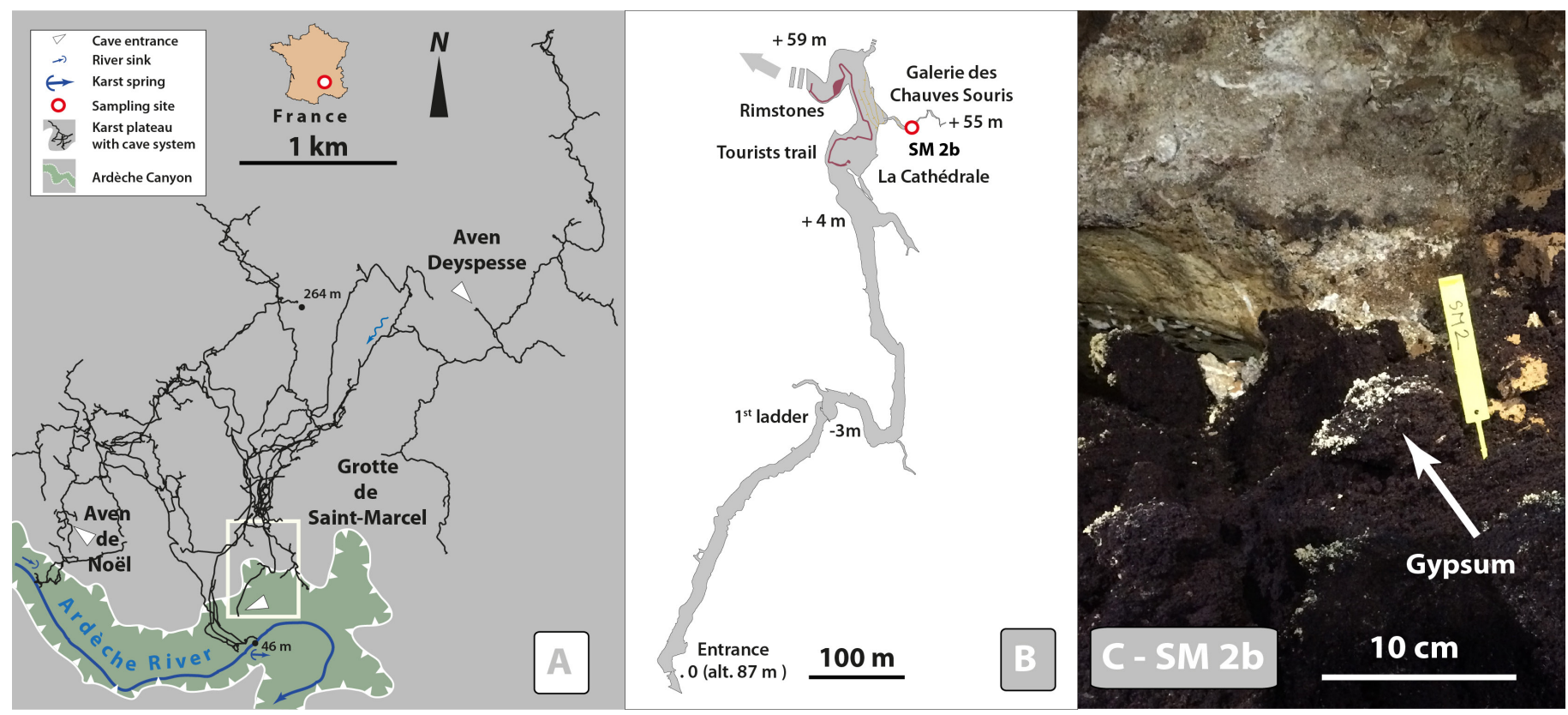

Fig. 8. A-B) Location of the Bats Passage and of SM $2 b$ sampling site in Saint-Marcel Cave (survey after M. Faverjon, SCSM); C) SM 2 sampling site in Saint-Marcel Cave. The guano accumulation is covered by spots of pale-yellow crystals (sample SM 2b) (Photo by A. Chroňáková).

truncated by the cliff, and is clogged by sediments in its inner part. It is developed along $\sim 200 \mathrm{~m}$ of rising passages, which split inward in two branches; passage size is about $10 \mathrm{~m}$ wide and 10 to $20 \mathrm{~m}$ high, with deep cupolas and chimneys where bat colonies gather (Fig. 9A). On the sampling day (15/09/2016), cave air was $15.1^{\circ} \mathrm{C}$, with $780 \mathrm{ppm} \mathrm{CO}$, and 95\% RH. The studied site is located in the main cave branch, at the foot of the last slope $20 \mathrm{~m}$ from the cave end. The guano deposit is about $6 \mathrm{~m}$ wide, and lateral extension shows it might be as thick as $3 \mathrm{~m}$. It is covered by dust sediments brought in by the repeated passage of visitors. Below this reworked sediment, the sticky guano is intact and the stratigraphy is reliable.

This guano accumulation was cored up to $60 \mathrm{~cm}$ depth and $\operatorname{six}{ }^{14} \mathrm{C}$ dates were obtained (Fig. 9B). It is composed of 3 main units, which boundaries are located at 13 and $21 \mathrm{~cm}$ depth. The upper and lower units are made of dark sticky guano, with 3 to $5 \mathrm{~mm}$ thick lighter brown beds in the lower unit. The central unit is made of a pure white soft crystalline powder (sample GM 2).

\section{Mescla Cave (Malaussène, France)}

Mescla Cave opens in a gorge in the Southern Alps at $184 \mathrm{~m}$ asl, $30 \mathrm{~km}$ upstream of the mouth of Var River in Nice. The cave contains $3.5 \mathrm{~km}$ of passage developed along strike, in the limb of an anticline showing strong dip $\left(45^{\circ}\right)$, in Portlandian (upper Jurassic) cherty limestone. The cave displays a looping profile typical of phreatic and epiphreatic flow (Fig. 10, Audra et al., 2002). Upper passages are dry, 


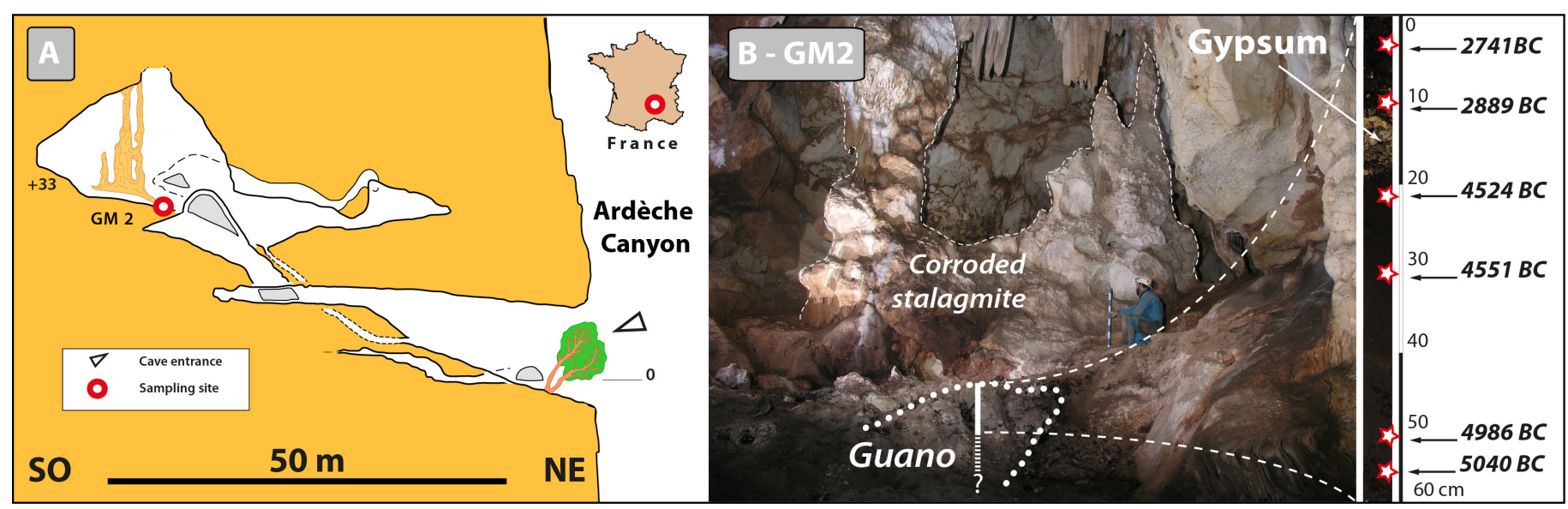

Fig. 9. A) Projected vertical profile of Grosse Marguerite Cave, which opens in the cliff of the Ardèche Canyon, France (after J.-Y. Bigot), with indication of sampling site; B) The GM 2 guano core accumulated between 5040 and 2741 BC, however its base was not reached. The guano is covered by dry clay and fire ash reworked along the pathway. A calcite stalagmite was strongly corroded by condensation waters forming above the guano (Photo by J.-Y. Bigot).

whereas the lower level corresponds to the active part of the river outflow. The upstream sump has been explored down to $-267 \mathrm{~m}$ below the entrance, ranking it among the deepest explored phreatic caves in the world. The deep component of the water is thermal $\left(23^{\circ} \mathrm{C}\right)$, with sulfated-chloride water (Reynaud, 2000). Calcite speleothems are present in the first sump, down to $-12 \mathrm{~m}$, demonstrating a recent rise of the water table due to sediment aggradation of the nearby
Var River. Currently bats and guano deposits are not frequent in the cave. However, the divers identified accumulations of bat bones in the second sump, at about $5 \mathrm{~m}$ depth, further confirming the recent rise of the water table. In the first sump, between 3 and 7 $\mathrm{m}$ depth, we collected white clay (Mescla 1) preserved in fissures protected from high velocity flow, and a fragment of black crust covering most of the walls (Mescla 2).

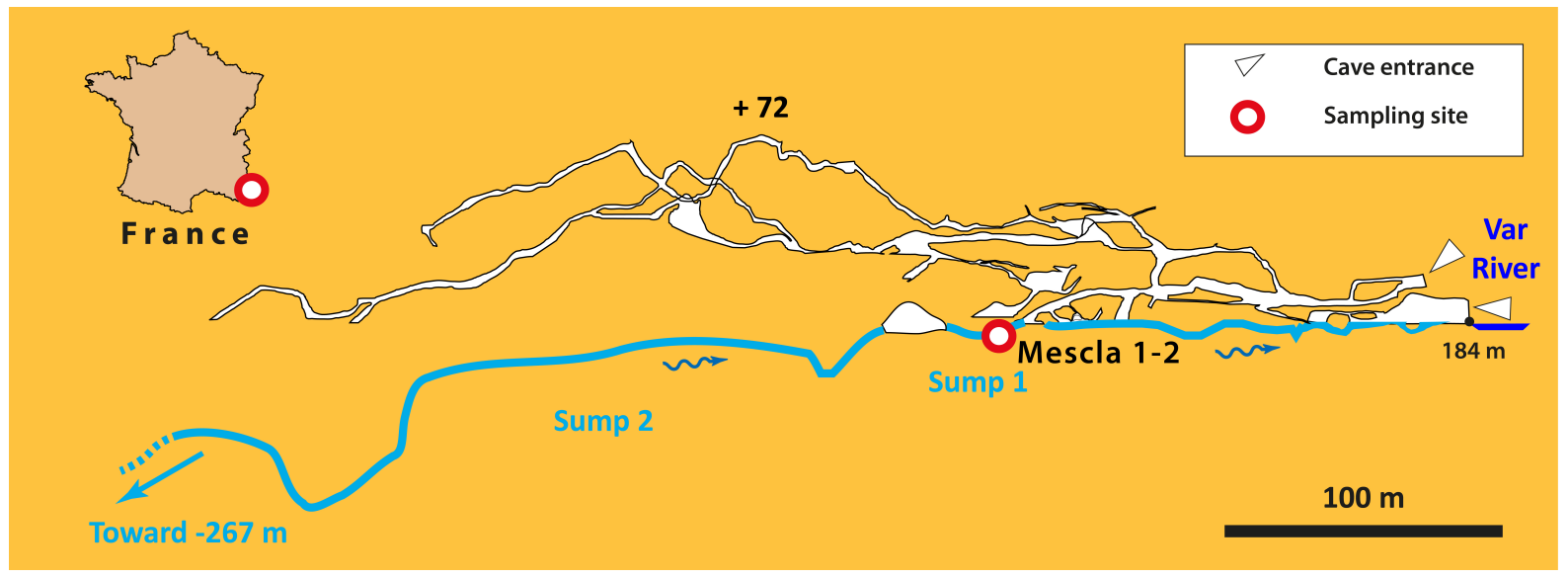

Fig. 10. Projected vertical profile of Mescla Cave showing the sampling sites (Survey after Audra et al., 2002).

\section{Aramiska Peštera (Dragožel, Macedonia)}

Aramiska Peštera opens at $660 \mathrm{~m}$ asl. It is a ponor cave located in the upstream parts of Kamenica Valley, part of the Crna Reka drainage basin, in the southern part of Macedonia (Fig. 11). It is developed in Upper Cretaceous limestone from sinking allogenic waters coming from the Pliocene-Early Pleistocene pyroclastic cover (Temovski, 2016). Back-flooding clay sediments are present throughout most of the cave, especially in the upper (older) parts. In the Room of Bones, remnants of human bones and skulls are covered with flowstone. Here we sampled pyroclastic-derived clay and sand material (AR1, AR2).

\section{Karši Podot Cave (Vrpsko, Macedonia)}

Karši Podot is a $200 \mathrm{~m}$-long horizontal hypogene cave located in Crna Reka Valley. It is formed mainly in Precambrian dolomitic marble, and partly in Pleistocene alluvial and travertine deposits (Fig. 12A).
Cave passages in the dolomitic marble formed by ghost-rock weathering with thermal waters leaving dolomitic sand residue (Temovski, 2013). The explorable passages were later opened due to backflooding from Crna Reka, removing the sediment, and redepositing it along with non-carbonate silt and clay coming from the allogenic waters or from the terrace deposits in which the northern parts of the cave are developed. A sediment profile in the Main Room has hydrothermally weathered dolomitic sand with fluvial clay and silt that was covered by a thick (30 $\mathrm{cm}$ to $1 \mathrm{~m}$ ) guano deposit (Fig. 12B). We sampled a brown layer (KP06) from this profile (Fig. 12C).

\section{Lekovita Voda Cave (Pravednik, Macedonia)}

Lekovita Voda Cave is a 90-m long old passage, remnant of a larger system, developed in Upper Cretaceous (Turonian) limestone, and located high in the Doljani Valley, a tributary to Crna Reka. The cave mostly consists of a single horizontal gallery 


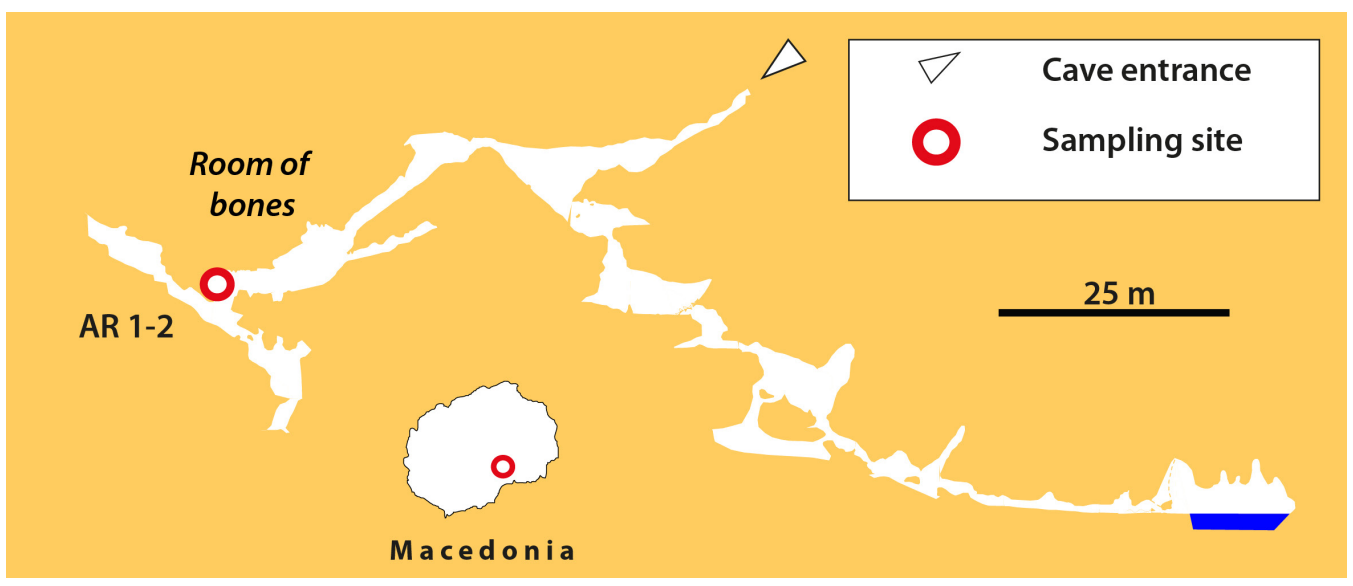

Fig. 11. Extended profile of Aramiska Peštera with the sampling location (Temovski, 2016).

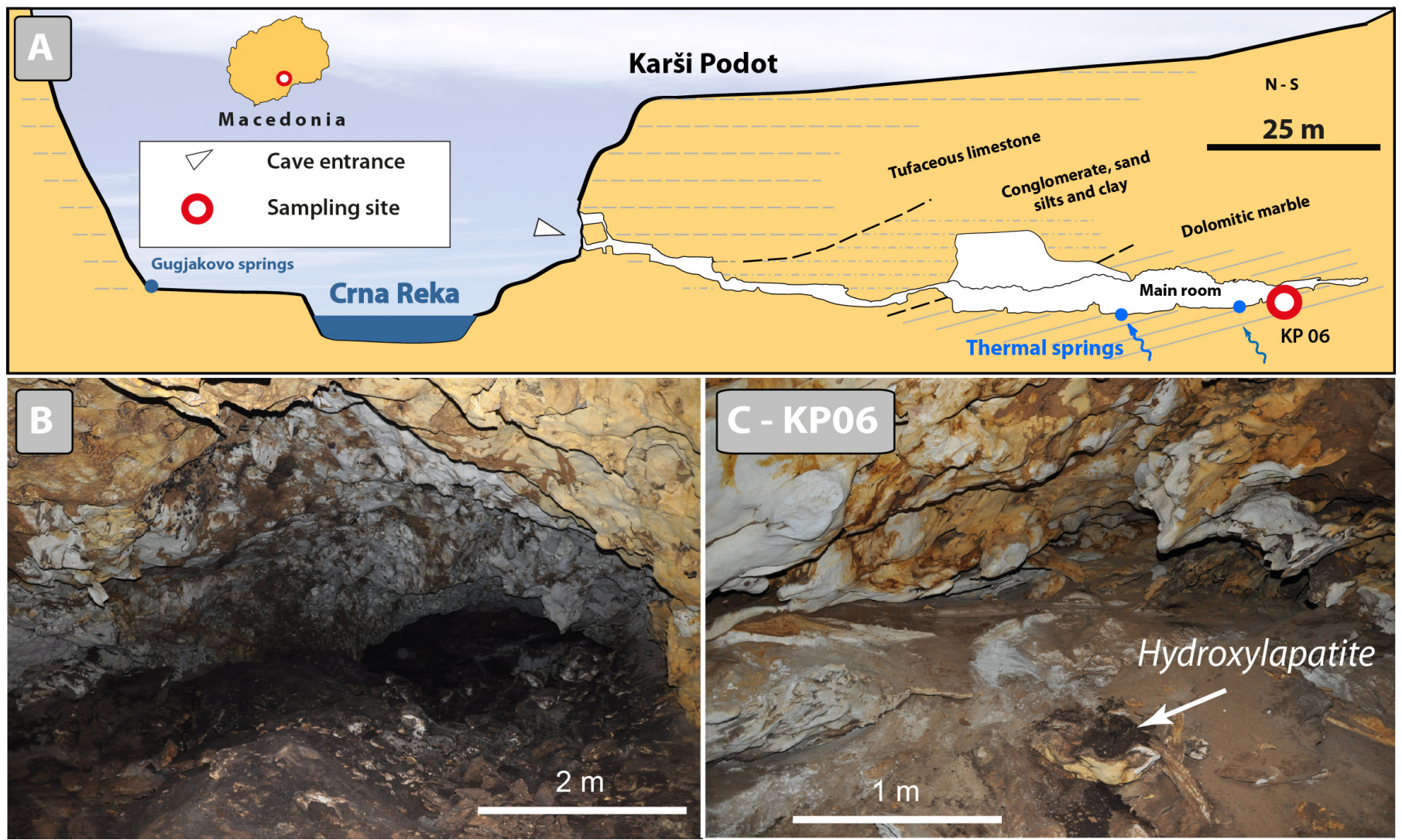

Fig. 12. A) Extended profile of Karši Podot Cave with sampling location (Temovski, 2016); B-C) Main Room in Karši Podot Cave, with detrital and weathered sand covered with thick guano deposits, where sample KP06 was collected (Photo by M. Temovski).

with a paragenetic ceiling morphology (Fig. 13A). It is mostly filled with gravel, sand, and clay sediments, which are partly exhumed and covered with thick flowstone deposits (Fig. 13B). It is presumed that the cave developed in Late Pliocene - Early Pleistocene, in relationship with the local geomorphic events (Temovski, 2016). The cave passage ends with a large sediment fill topped by a thick flowstone deposit, nearby which in a small niche we sampled a detrital yellow clay (LEK1).

\section{The Monte Inici cave system - Grotta dell'Eremita and Abisso dei Cocci (Castellammare del Golfo, Trapani, NW Sicily, Italy)}

Mount Inici is an isolated massif reaching $1064 \mathrm{~m}$ asl, close to the NW Sicilian coast. Two caves belong to the Monte Inici system: Grotta dell'Eremita and Abisso dei Cocci, both opening at about $500 \mathrm{~m}$ asl on the southern scarp of the mountain (Fig. 14). These are the two deepest caves in Sicily, with depths of 306 and $361 \mathrm{~m}(+61 /-300)$, and developments of 2.9 and $2.1 \mathrm{~km}$, respectively (Messana, 1994). They occur in Lower Jurassic limestones and dolomitic limestones (Inici Fm.), and Upper-Middle Jurassic reddish-gray limestones (Buccheri Fm.). The caves are typical 3D mazes with large, gently dipping galleries, and chambers connected by vertical shafts. They are of hypogene origin (Vattano et al., 2013, 2017), related to the nearby thermo-mineral spring with temperatures of up to $50^{\circ} \mathrm{C}$ (Grassa et al., 2006). Due to the heating of the rock above the thermal aquifer, the caves are warm $\left(17.4\right.$ close to the entrances, up to $21.1^{\circ} \mathrm{C}$ in the lower parts) and dry (70-90\% RH); $\mathrm{CO}_{2}$ may reach $0.4 \%$ in the lowest confined areas.

Both caves are rich in phosphate minerals derived from large fossil bat guano deposits and occur especially in the deeper large rooms. Samples were taken in various parts, in small exploration trenches 

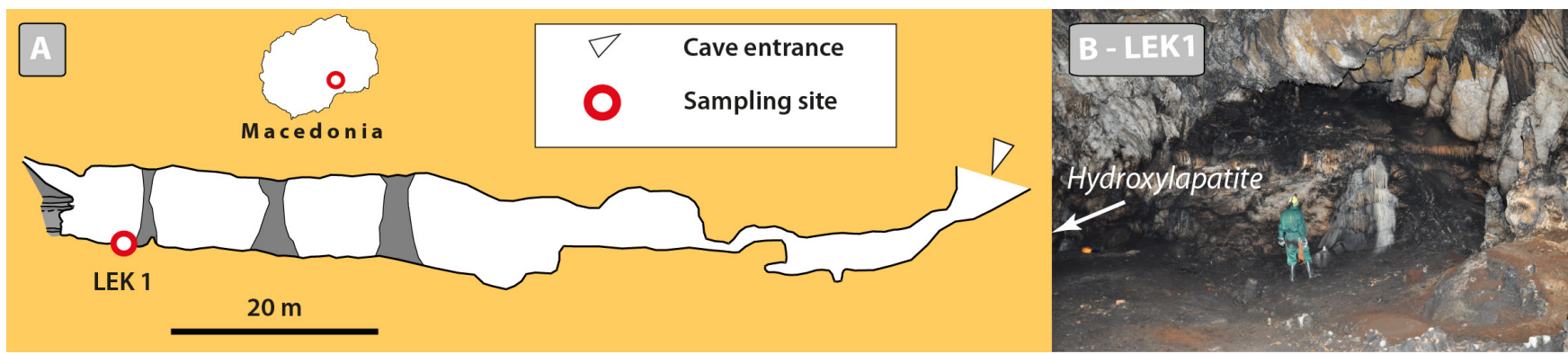

Fig. 13. A) Profile of Lekovita Voda Cave with sample LEK 1 location (Temovski, 2016); B) View of the sediment choke at the southern end of Lekovita Voda Cave, with clay filled floor covered by thin black soot coating due to frequent visitors (Photo by M. Temovski).

Eremita

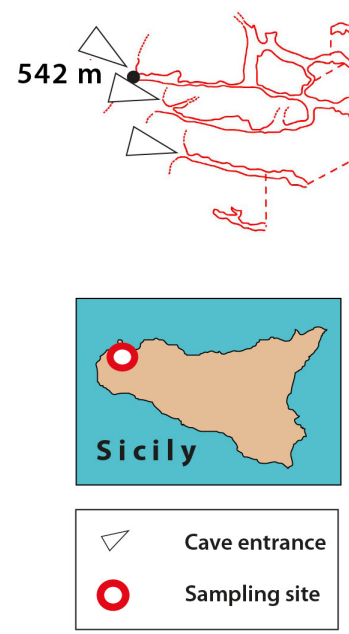

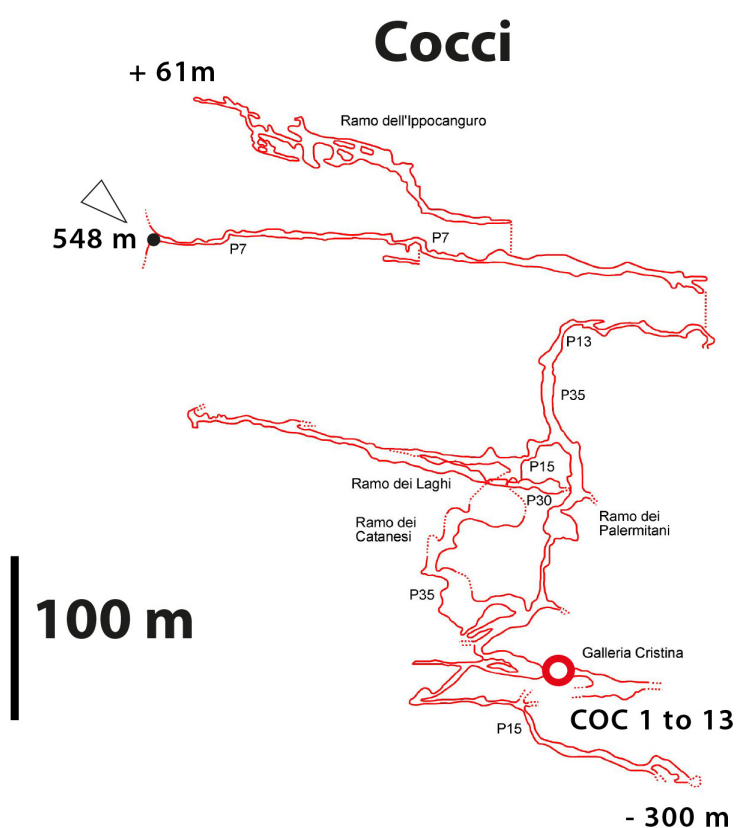

Fig. 14. Vertical profile of Grotta dell'Eremita and Abisso dei Cocci (after GS CAI Palermo and CSE Catania), with indication of sampling sites and their location within Sicily (inset map).

dug in old bat guano deposits until the underlying limestone was reached. Some broken stalactites found on the floor were also taken.

In Eremita Cave we collected 17 samples (Fig. 1415): a grey-white laminated stalactite (ER1ab), soft laminated guano layers of various colors (white, yellowish, greenish) (ERE 3 and ERE 6 to 15), and a beige earthy part of a black crust (ERE 4-5) at the contact between rock and guano. In Ramo dei Cinque Passage, below a cone of old guano, we sampled a light beige soft powdery material in a white layer (ERE15), a white and pinkish earthy material from a yellowish layer (ERE16 and Eremita3), and a bright yellow layer (Eremita4).

In Abisso dei Cocci many samples were taken below the Cristina Passage (Fig. 14 and 16): white prismatic translucent crystals (COC1) found underneath boulders, a yellowish to white powder (COC4), a brownish crust covering the many boulders along this passage (COC5), a lemon-yellow colored vitreous layer (COC7), a part of a white layered stalactite showing no reaction with $\mathrm{HCl}$ (COC9), and a dark crust (COC10). In a shallow trench dug into the floor sediments a sequence of layers has also been sampled: a lower white layer in contact with the unaltered limestone below (COC11a), a layer with greenish spots inside a white mass (COC11b1) and with pinkish crystals (COC11b2). White microcrystalline powder was recovered in the center of the gallery (COC13).

\section{Acqua Fitusa Cave (San Giovanni Gemini, Agrigento, Sicily, Italy)}

Acqua Fitusa is an inactive water-table sulfuric acid cave (De Waele et al., 2016; Vattano et al., 2017). It is located in Central Sicily (Fig. 17A) along the north-eastern fault scarp of a N-S oriented westwardvergent anticline forming the Mt. La Montagnola. The cave formed in the Upper Cretaceous rudist breccia member of the Crisanti Formation, composed of conglomerates and reworked calcarenites. Chloridesulfate alkaline-earth waters with temperature of $25.2^{\circ} \mathrm{C}$ (Grassa et al., 2006) still emerge $300 \mathrm{~m}$ to the north and at a lower altitude with respect to the cave. The cave consists of three stories of subhorizontal conduits, arranged in a maze pattern following sets of joints, forming large rooms on their intersections; its total length is $700 \mathrm{~m}$ and has a vertical range of 25 $\mathrm{m}$ (Fig. 17A). Due to the sulfuric acid speleogenesis (SAS), replacement gypsum crusts are present in fissures and pockets, and totally coat narrow blind passages. The cave environment is relatively dry, with a temperature of $12.8^{\circ} \mathrm{C}$ and $\mathrm{RH}$ of $76.5 \%$ (Dec. 2011). It hosts a community of Rhinolophus euryale, R. ferrumequinum, R. hipposideros, Myotis myotis, $M$. capaccinii, and $M$. schreibersii (Fulco et al., 2015). Samples were taken in the central part of the entrance chamber, where big blocks of collapsed limestone are covered with guano deposits and a dark brown crust has developed (FIT3) (Fig. 17B). 

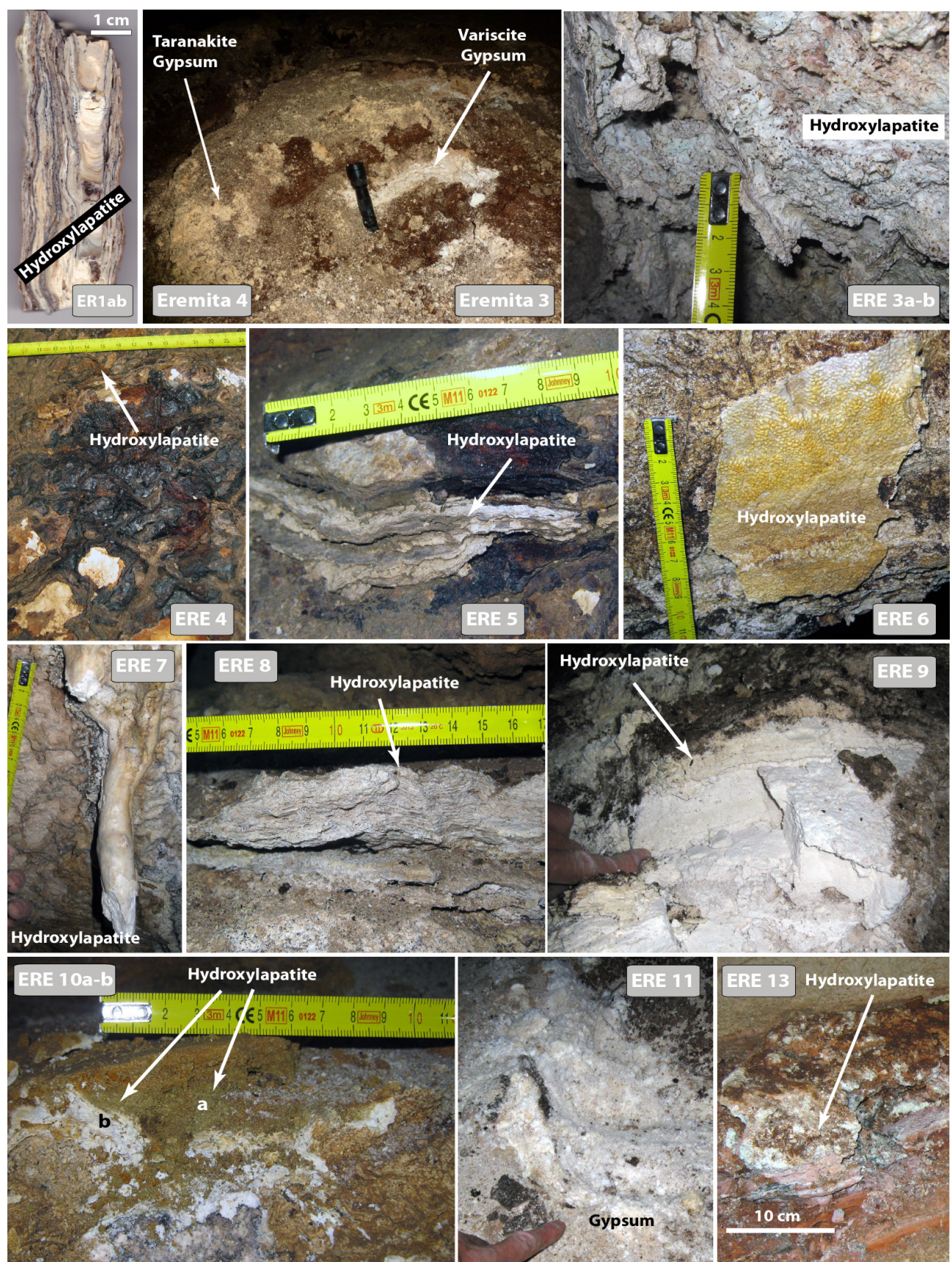

Fig. 15. Phosphates and sulfates sampled in Eremita Cave (see text for further details) (Photos by J. De Waele and Ph. Audra).
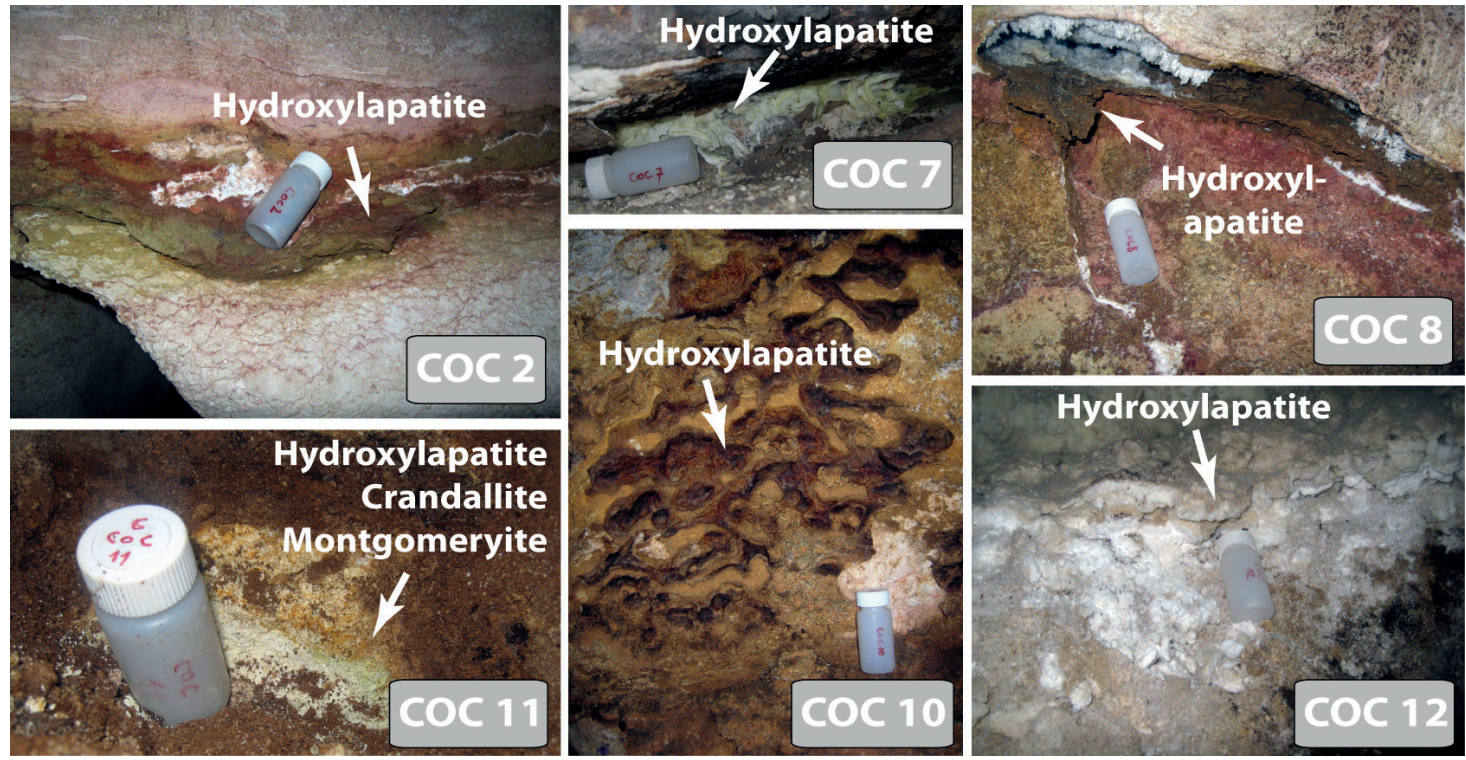

Fig. 16. Phosphates sampled in Cocci Abyss (Photo by J. De Waele). 


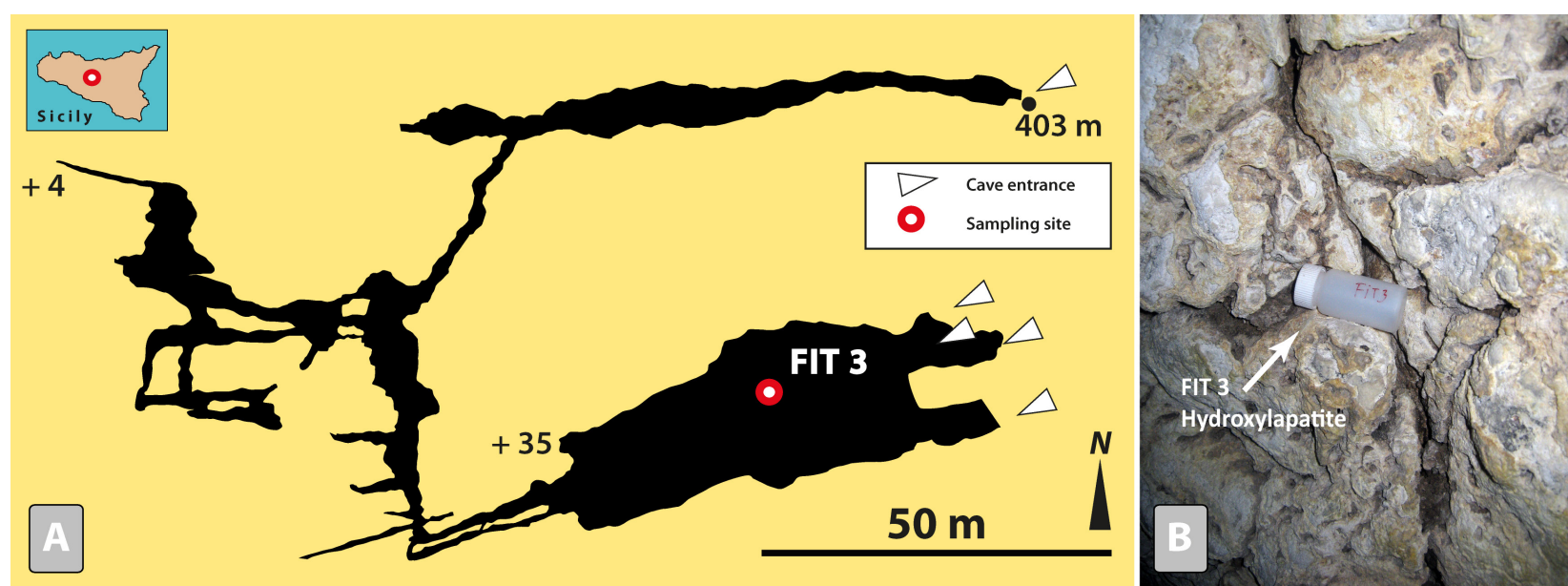

Fig. 17. A) Plan view of Fitusa Cave, with indication of the sampling site (Survey ANS Le Taddarite, Vattano, 2012). In inset, location of the cave in Sicily; B) Dark crust sampled in Fitusa Cave (Photo by J. De Waele).

\section{Palombara Cave (Melilli, Syracuse, Sicily, Italy)}

Palombara Cave opens at $150 \mathrm{~m}$ asl at the foot of the Monti Climition a plateau that inclines toward Syracuse Bay. The plateau is made of Miocene (BurdigalianSerravalian) calcarenites, namely the Monti Climiti Formation (Lentini \& Carbone, 2014). It is part of the Hyblean Plateau, which belongs to the African Plate. Volcanoes were active in this area during the PlioPleistocene until 1.4 Ma. The area was continuously uplifted during the Pleistocene as evidenced by several marine terraces and paleocliffs. Palombara Cave is about $800 \mathrm{~m}$ long, with a depth of $\sim 80 \mathrm{~m}$ (Ruggieri, 2000). It consists of large subhorizontal passages cut by narrow mazes and shafts (Fig. 18A). The entrance is a collapse shaft that opens on the plateau. The cave displays phreatic morphologies, feeders, bubble trails, pointing toward a hypogene origin in relationship with deep $\mathrm{CO}_{2}$ degassing, possibly brought about by the Hyblean magmatic bodies, and with the uplifting stages recorded by the Pleistocene marine terraces (Vattano et al., 2017). The cave contains fine-clay sediments, originating from clastic material brought in from the surface. Two samples display reverse paleomagnetic orientations, showing that the cave itself should be older than $780 \mathrm{ka}$, which would be consistent with the lowest mean uplift rates of 0.2 $\mathrm{mm} / \mathrm{a}$ proposed by some authors (Dutton et al., 2009, and references therein). After its opening to the surface, the cave was accessible to Neolithic tribes and to bats. The latter have left extensive guano deposits, among which the pile in the Guano Chamber reaches $\sim 8-10 \mathrm{~m}$ in height. Five species are currently present (Myotis myotis, Miniopterus schreibersii, Rhinolophus ferrumequinum, $R$. euryale, and $R$. mehelyi). The cave is protected by a Regional Law (Di Maggio et al., 2012). Two sites were sampled for phosphate mineralogy. After the main climb and before the Guano Chamber, an old guano deposit (P5) is covered by a colorful crust (Fig. 18B). A little further into the cave, an old guano deposit naturally cut by erosion is covered on a vertical face by a pale violet crust (PA23) (Fig. 18C).

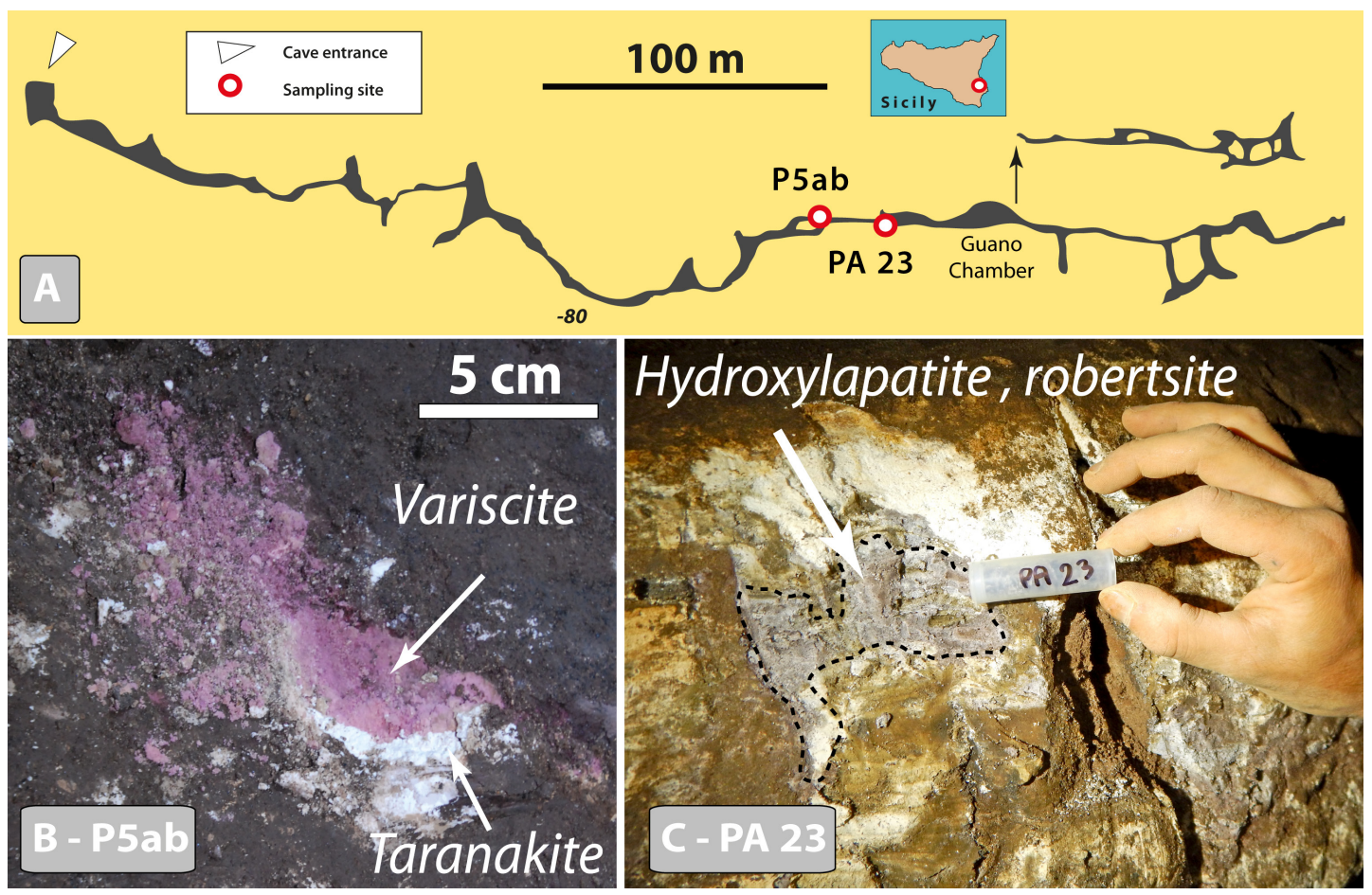

Fig. 18. A) Vertical profile of Palombara Cave (after Ruggieri, 2000), with indication of sampling sites; B) Sample P5 displaying stratigraphic succession of old guano covered by white and purple layers (Photo by M. Vattano); C) Sample PA23; A pale violet crust covers an old guano profile (Photo by D. Cailhol) 


\section{Monello Cave (Syracuse, Sicily, Italy)}

Monello Cave opens at $100 \mathrm{~m}$ asl in the same area as Palombara Cave, at the foot of the Monti Climiti paleocliff. Also, this cave is preserved as nature reserve (Di Maggio et al., 2012). It consists of $\sim 540 \mathrm{~m}$ of galleries developed along faults to a depth of $40 \mathrm{~m}$ and well decorated large chambers (Fig. 19A). To the south, a series of shafts lead to the lower point of the cave. As Palombara, numerous feeders, bubble trails, and ceiling channels point toward a hypogenic origin. Some clastic material was introduced by sinkholes and deposited as decantation clay in the deep parts. They bear normal paleomagnetic orientations, thus younger than 780 ka. Archeological material from Upper Neolithic has been found. Great accumulations of guano are present especially in the first large chamber; however, due to the closure of the cave, only few individuals of Rhinolophus ferrumequinum are now present. The lower gallery hosts pieces of collapsed calcarenite rocks, some being covered by a thin layer of brown decantation clay (Fig. 19B). Its surface is hardened by a thin $(<1 \mathrm{~mm})$ brown crust (MO 4) (Fig. 19C-D).

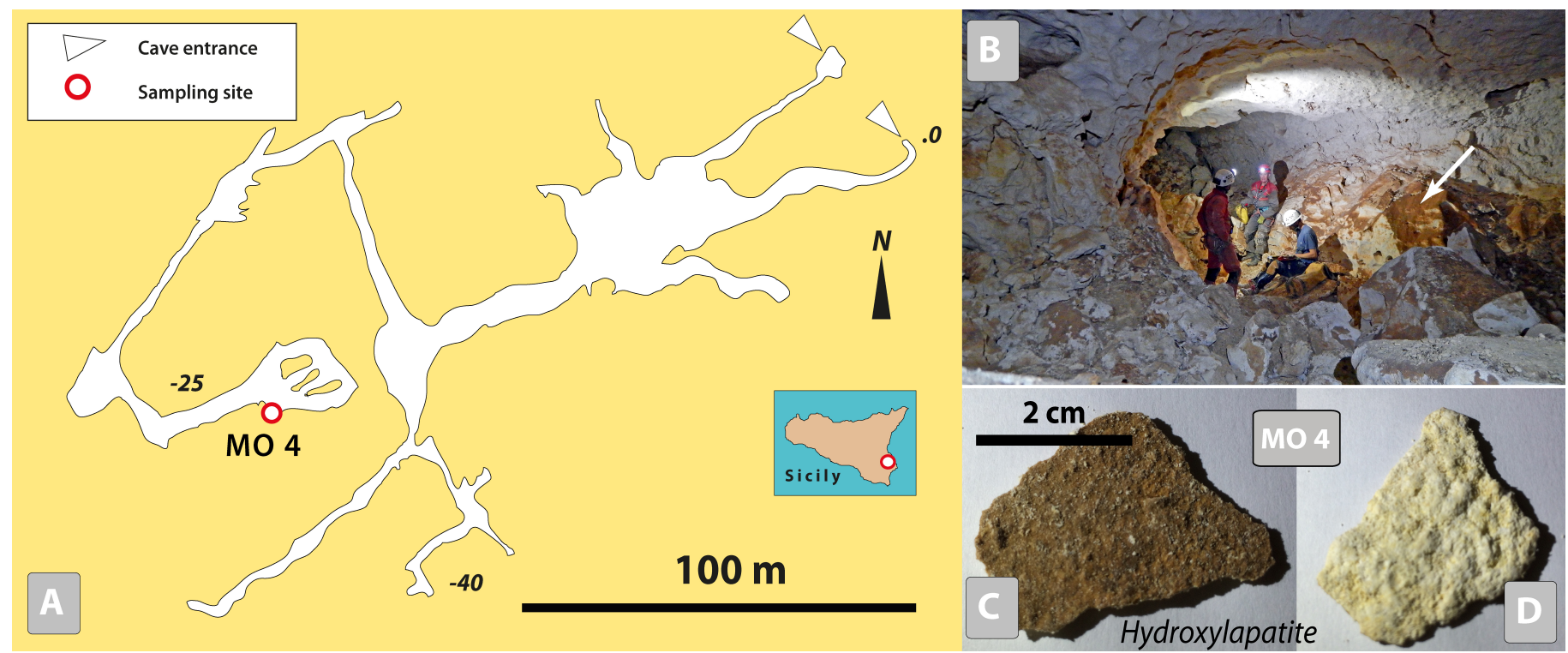

Fig. 19. A) Plan view of Monello Cave (after Ruggieri, 2000), with indication of sampling site; B) Floor of the lower gallery in Monello cave covered by collapsed calcarenite blocks, which in turn are covered by a thin crust of brown decantation clay and phosphate (Photo by D. Cailhol); C) closeup view of the upper part of the crust in B; D. lower side of the crust, at the contact with the calcarenite (Photos by Ph. Audra).

\section{Grotta Scrivilleri (Priolo Gargallo, Syracuse, Sicily)}

Grotta Scrivilleri, opening at $157 \mathrm{~m}$ asl, is an over $2 \mathrm{~km}$-long maze of hypogene origin with most of the passages guided by prominent fractures (Fig. 20A). The cave is developed in the Miocene calcarenites of the Syracuse area, such as the Palombara and Monello caves. Since the cave was just recently opened by digging, no bats are present inside. At the bottom of the Prima Frattura Chamber, about
$300 \mathrm{~m}$ from the entrance, a mixed deposit shows alternation of laminated clay deposited by flooding waters and white soft sandy residue originating from wall weathering by condensation (Fig. 20B). A thin dark-brown layer of presumed old guano (SC4) is present below the upper sandy layer, showing that some connection to the surface through which bats could have entered the cave existed sometime in the past.

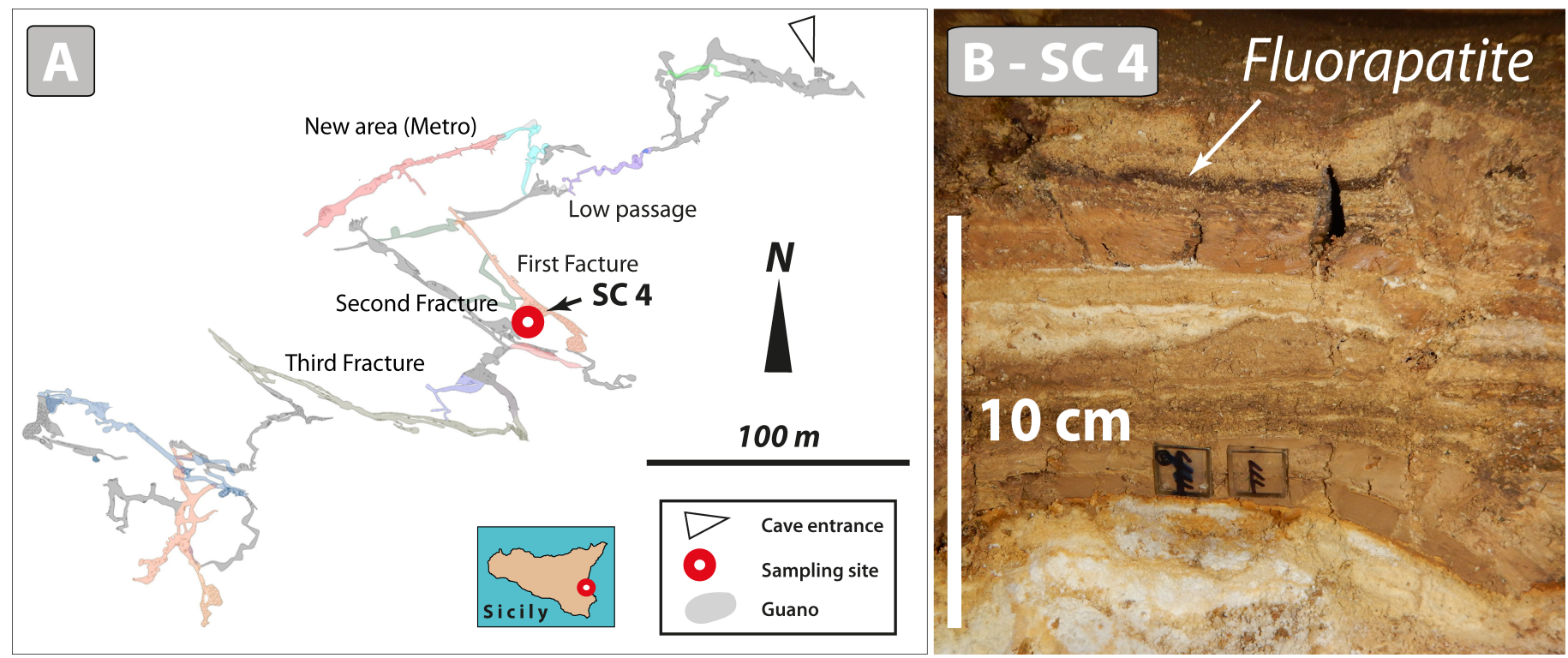

Fig. 20. A) Grotta Scrivilleri plan view, with sampling location (from Centro Speleologico Etneo, Gruppo Speleologico Siracusano, Speleo Club Ibleo); B) Sediment profile from where SC4 sample (a thin dark brown phosphate layer) was collected (Photo by D. Cailhol). 


\section{Personaggi Cave (Montevago, Agrigento,}

\section{Sicily, Italy)}

The Grotta dei Personaggi is known since the early 1900 s and is famous for the archeological findings that cover a period from the Neolithic to historical times. The cave opens at $350 \mathrm{~m}$ asl along a fault scarp in the NW sector of Mt. Magaggiaro and is developed in well-bedded white platform limestones (Inici Formation, Lower Jurassic) and in nodular or massive reddish to brown pelagic limestones (Buccheri Fm., Upper-Lower Jurassic) of the Saccense Domain (Di Stefano et al., 2013). Thermal springs, characterized by chloride-sulfate alkaline-earth waters with an average temperature of $39.2^{\circ} \mathrm{C}$ (Grassa et al., 2006) are located about $3 \mathrm{~km} \mathrm{NW}$ of the cave, which has a total length of $\sim 1.7 \mathrm{~km}$ and a relief of $47 \mathrm{~m}$
$(+15 \mathrm{~m} /-32 \mathrm{~m})$. It consists of close-to-horizontal passages that follow bedding and fault planes forming a maze pattern with deep feeders along fractures pointing toward a hypogene origin (Fig. 21; Vattano et al., 2017). The cave morphologies are mainly linked to condensation-corrosion processes by convective airflow, such as upwardly developing cupolas, stacked spheres, weathered walls and boxworks. Alluvial deposits are absent. The cave hosts a large bat colony of Rhinolophus euryale responsible for an extensive amount of guano. A previous study of mineral chemistry shows the presence of phosphates, iron, manganese, and silica spherules, which are interpreted as being concentrated through microbial communities processing the impurities from host rock and clay (Vattano et al., 2015).

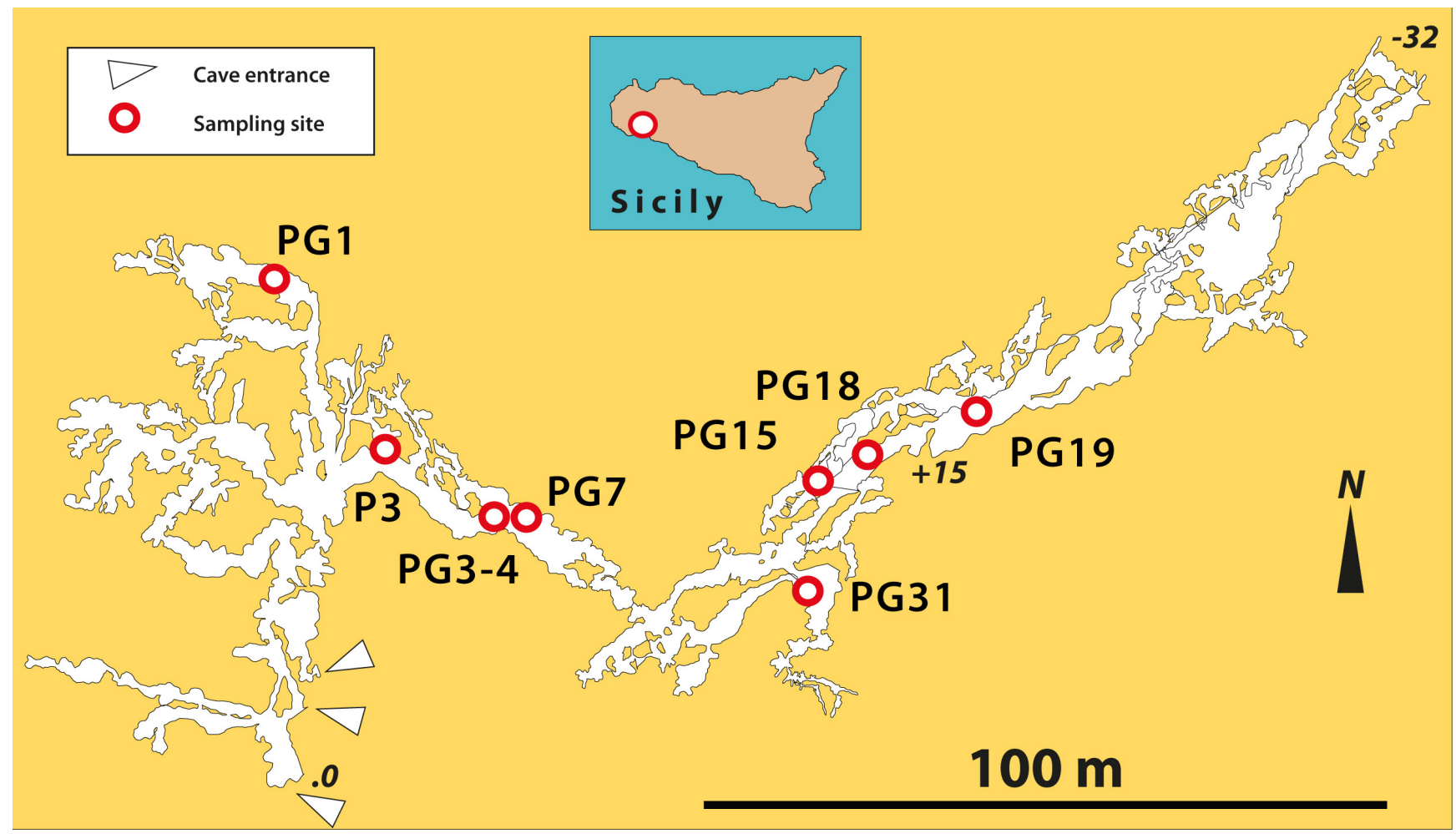

Fig. 21. Plan view of Personaggi Cave (Survey by ANS Le Taddarite, Vattano, 2014), with sample location.

Several soft samples were collected (Fig. 22): the lower black part of a crust in a cupola (PG1), the white part (PG3) and the blackish layer (PG4) of a deposit on a block, a blackish paste between white and reddish parts on the contact between guano and wall (PG7), a whitish paste at the bottom of gallery (PG15), a whiteblack-yellow crust attached to guano (PG18), a whiteblack-yellow crust in guano pot (PG19), a black crust on wall (PG31), and a multicolor green-white crust (P3).

\section{Salnitro Cave (Sambuca di Sicilia, Agrigento, Sicily, Italy)}

Salnitro Cave develops in Eocene carbonate breccia resting on the limestones of the Inici Formation. The Mt. Arancio, where the cave opens at $252 \mathrm{~m}$ asl, is an anticline limb cut by the antecedent canyon of Tardara. Salnitro Cave has two entrances and is composed of three, $20 \mathrm{~m}$ large and high chambers connected by short passages. Its total development is $\sim 260 \mathrm{~m}$ and it has a depth of $18 \mathrm{~m}$ (Fig. 23A). The original shape of the cave voids is hidden by many rock falls, while the floor is covered with debris and large piles of guano (Fig. 23B). The roof is sculptured by cupolas probably related to condensation-corrosion processes above the guano heaps. The cave has been known for a long time, and in the past the guano deposits were mined as fertilizers. Salnitro Cave is home to Myotis myotis, M. capaccinii, Miniopteris schreibersii and only occasionally to Rhinolophus euryale and Pipistrellus kuhlii. Several samples of dark brown crusts were collected from boulders and cave walls in several areas of the main room (SAL1-4, Fig. 23E). Close to a dripping location (Fig. 23C), a powdery white crust (SN3, Fig. 23D) covered the dark guano deposits at the edge of wet guano, where evaporation occurred.

\section{Carburangeli Cave (Carini, Palermo, Sicily)}

Carburangeli Cave is located close to the city of Palermo. It is a 400-m long cave (Fig. 24), mainly horizontal, opening at $22 \mathrm{~m}$ asl on an elevated marine terrace attributed to MIS 5, at the foot of a paleocliff. 

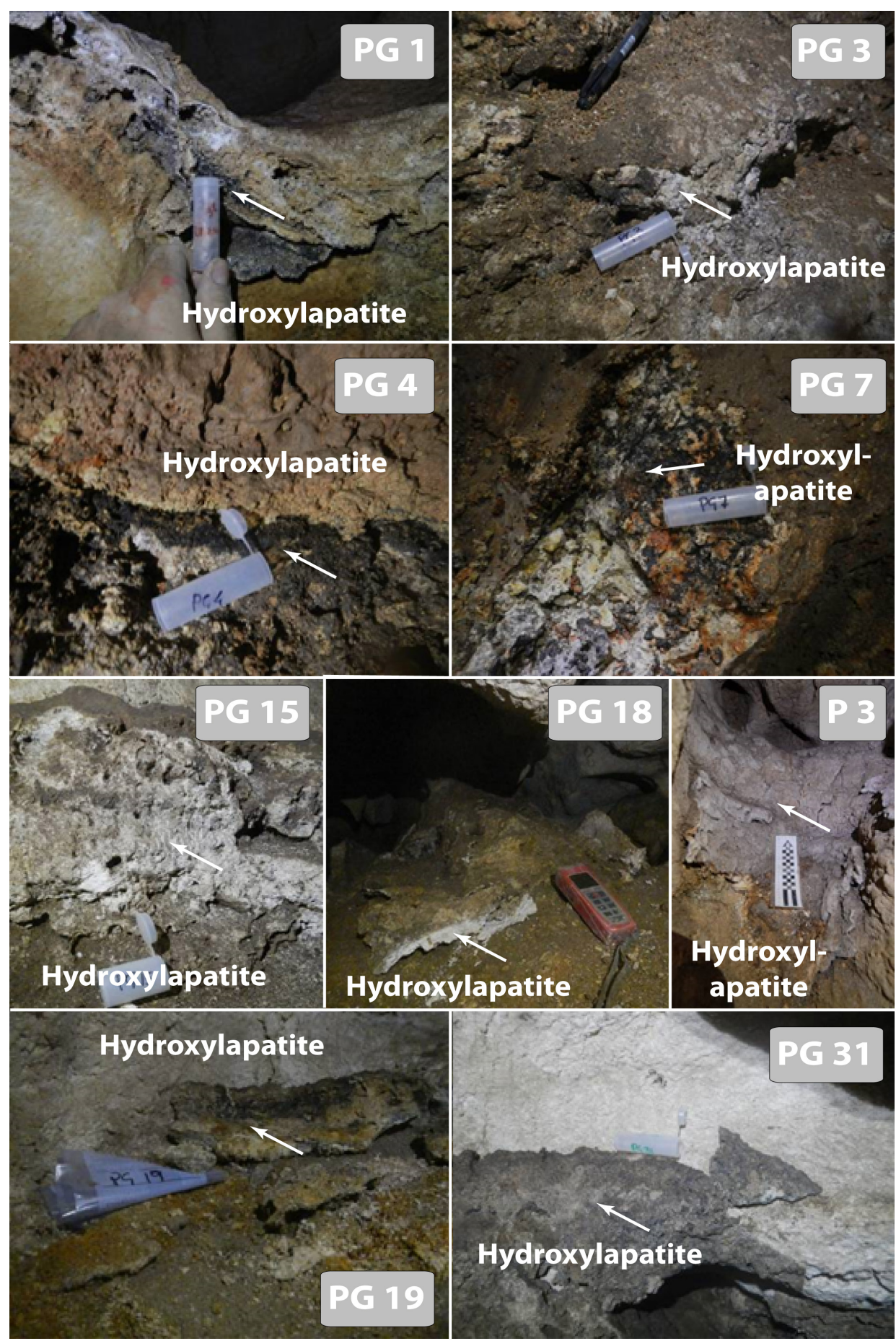

Fig. 22. Phosphates sampled in Personaggi Cave (Photos by M. Vattano).

The entrance part is developed in Pleistocene calcarenites and conglomerates, whereas the inner part extends in Triassic and Lower Jurassic limestones and dolomitic limestones (Madonia et al., 2003). The cave was probably a flank margin cave, transformed into resurgence at a later stage. Carburangeli Cave is famous for its archeological findings of Paleolithic and Neolithic age and is also of paleontological interest (Sicilian dwarf elephant). The cave is protected as natural reserve (Di Maggio et al., 2012), and it hosted an important colony of Myotis myotis. Three samples of phosphates were collected in the room where the bats are concentrated (CA1 to 3 ).

\section{Pertosa-Auletta Cave (Pertosa, Salerno, Italy)}

Pertosa-Auletta is a show cave. It opens on the flanks of the Tanaro Valley, along the eastern slopes of the Alburni Mts., and develops in well-bedded Jurassic micritic limestones (Santo, 1988). The cave is a resurgence with an important underground river in one of the galleries, and some fossil branches (Fig. 25A). The development is little over $3 \mathrm{~km}$. It has two entrances (263 and $268 \mathrm{~m}$ asl, respectively), a positive altitude difference of $45 \mathrm{~m}$, and temperatures ranging between 12.2 and $13.9^{\circ} \mathrm{C}$. In several areas of the fossil branches old guano deposits are present (Fig. 25B). These were exploited in the 1940s, but parts of these sediments can still be seen along the show cave trail. Dark brown crusts are visible along the lower part of the walls and filling ceiling cupolas (samples P1 to 3). Along the underground river bank, a thick guano deposit is cut and shows an alternation of brown and more yellowish layers (P4, Fig. 25C). 


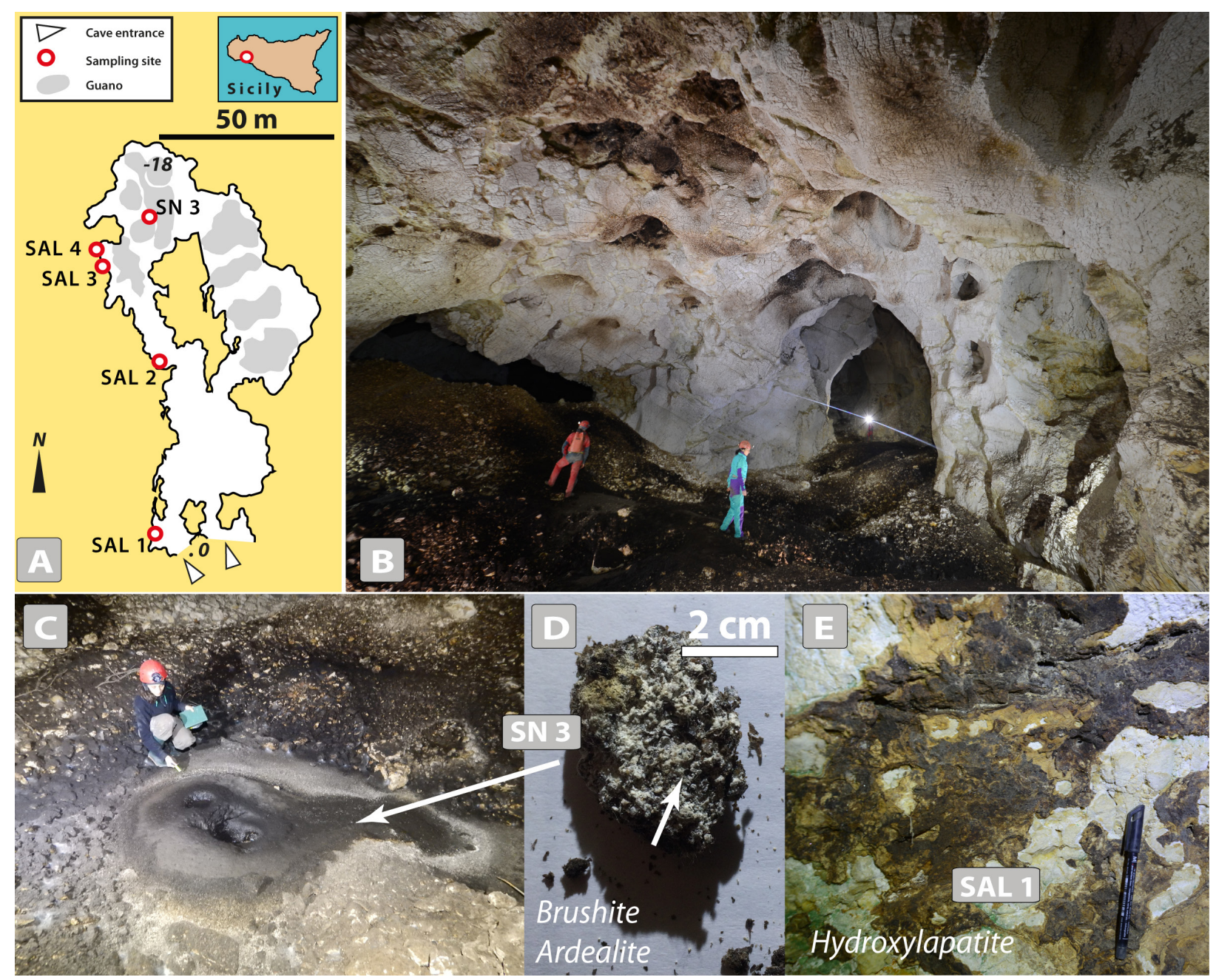

Fig. 23. A) Plan view of Salnitro Cave with sample locations (Survey ANS Le Taddarite, Vattano, 2010, 2015); B) Last chamber where extensive guano deposits cover the blocky floor (Photo by M. Vattano); C) The guano cone is wet in the center because of dripping, whereas its edge, D, is dry, allowing the crystallization of a ring of soft crystals; E) dark brown crust on the wall (Photos by M. Vattano and Ph. Audra).

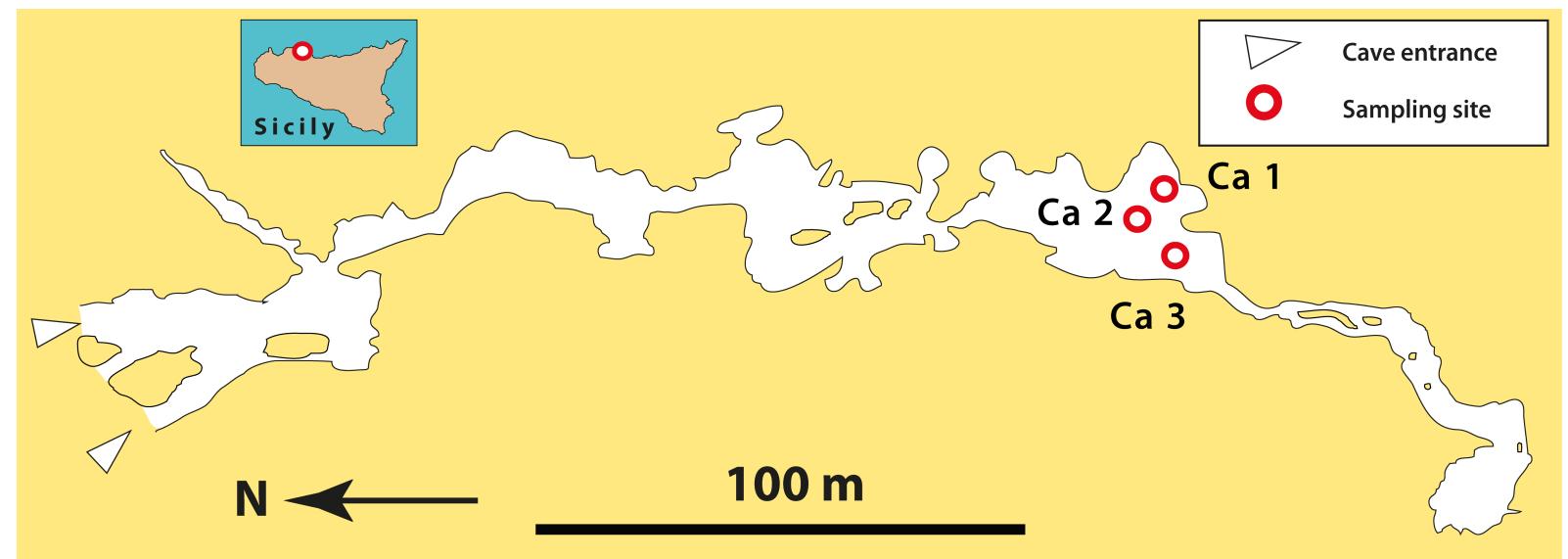

Fig. 24. Plan of Carburangeli Cave (Survey by A. Conigliaro, R. Di Pietro \& D. Gueci, 1996-1997), with sampling locations.

\section{Toirano cave system (Toirano, Savona, Italy)}

The Toirano cave system is located in the Varatella Valley and develops in dolostones and dolomitic limestones of the San Pietro ai Monti Formation (Triassic). From the lower (186 $\mathrm{m}$ asl) to the upper level $(247 \mathrm{~m}$ asl), the caves are organized as follows: Básura, Santa Lucia Inferiore, Santuario, and Colombo. Morphological indices suggest this cave system originated from rising, possibly hypogene flow, as a small thermal sulfidic spring surfaces in the village of Toirano. Cosmogenic-nuclide (Al-Be) burial dating of the fluvial gravels found in the upper Colombo tier yielded an age of $2 \mathrm{Ma}$, showing that the valley was a Messinian canyon eventually filled with thick Pliocene gravels, which were later eroded. Phosphates have been found and sampled only in the highest level of Colombo, which is a horizontal $310 \mathrm{~m}$-long cave (Fig. 26A). Here, important bat guano deposits and associated intense condensation-corrosion features show that bats have used this cave for a long time. The cave is of archeological interest, as are most of the caves in the area, and guano deposits have been trenched by scientific excavations. We sampled a hard-yellow crust covering an intact old guano heap (C1, C3) (Fig. 26B). 


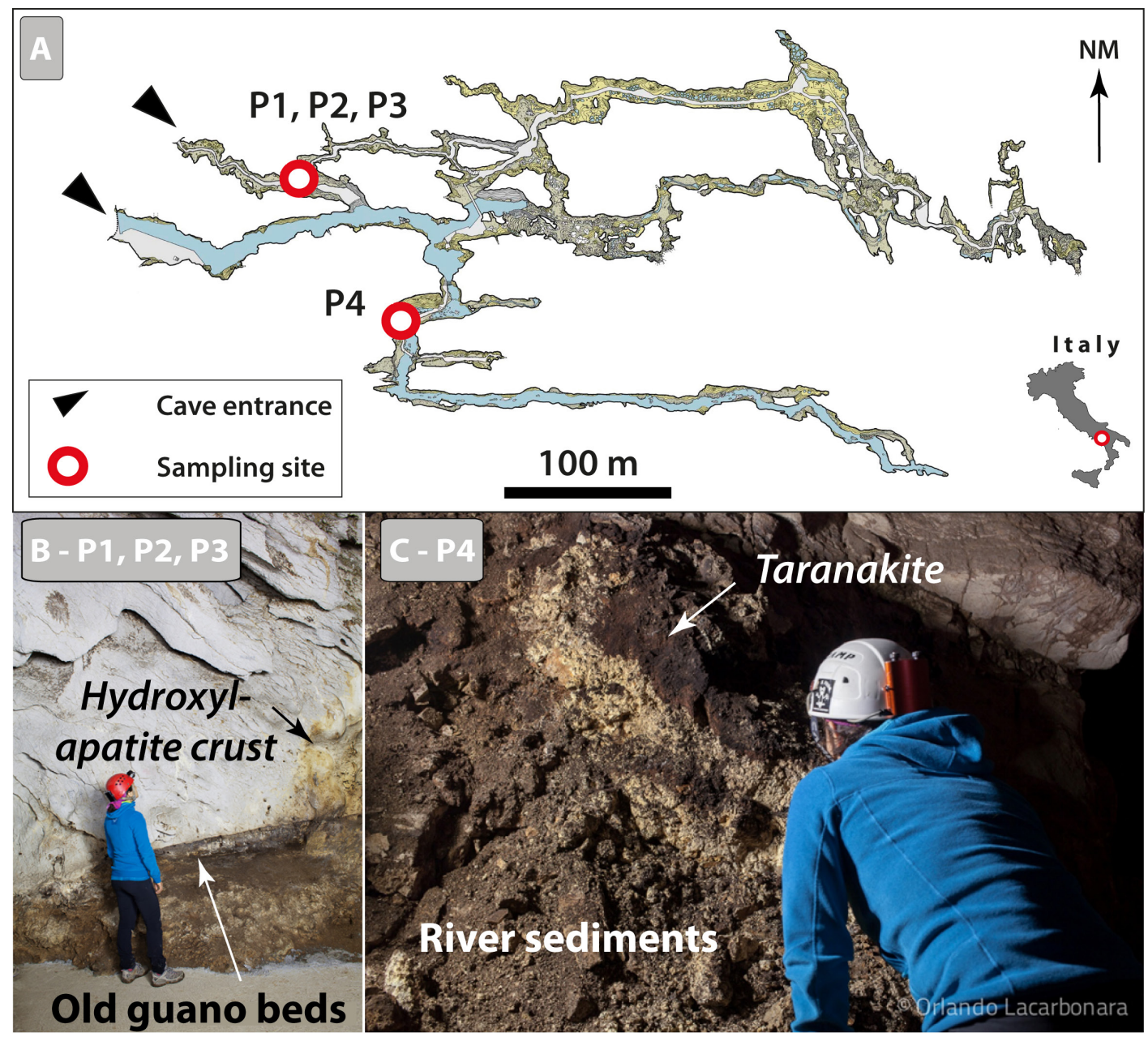

Fig. 25. A) Pertosa-Auletta Cave survey and sampling sites (survey F. Larocca, CRS "Enzo dei Medici");

B) sampling area of P1, P2, P3, with the old guano deposits on the lower part of the cave walls (dark areas);

C) sample P4 is located on river sediments (Photos by O. Lacarbonara).
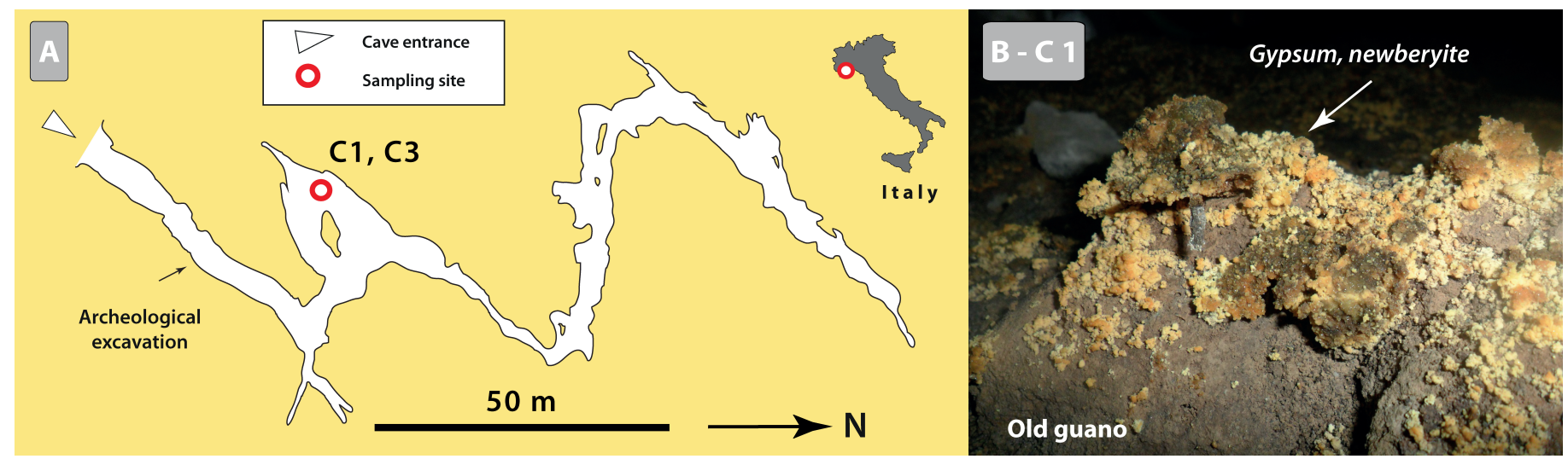

Fig. 26. A) Location of sampling sites in the highest tiers of Colombo Cave (after GS Cycnus, Toirano); B) Close-up view of sample C1 (Photo by J. De Waele).

\section{Corona 'e sa Craba Cave (Carbonia, sw Sardinia)}

Corona 'e sa Craba is a 250-long cave entirely carved in a quartzite vein at the contact with Cambrian dolostones (Sauro et al., 2014). The small entrance to the cave has been excavated by local mineral collectors and opens at an altitude of $260 \mathrm{~m}$ asl (Fig. 27A). In the Corona 'e sa Craba area there are several mines for $\mathrm{Pb}, \mathrm{Zn}$, and $\mathrm{Ba}$ ores, which were active until the early 1980 s. The cave consists of a series of chambers and lacks the typical carbonate speleothems. After the first room, the cave continues with a wide and high gallery that hosts a large guano deposit generated by an important bat colony inhabiting the cave during spring-early summer. The rock walls are covered with powdery material and crusts of colors ranging from reddish to violet, brown, greyish, white, pale pink, blue, and black. These secondary minerals are mainly composed of oxides-hydroxides, sulfates, and phosphates. The sulfates are derived from the acid corrosion by sulfuric acid in a late stage of cave development (Sauro et al., 2014). Phosphates, on the other hand, derive from the interaction of the host rock and its minerals with fresh or old guano. Besides the common hydroxylapatite and taranakite, the rare minerals robertsite, spheniscidite (Fig. 27B), vashegyite, strengite, and possibly leucophosphite and berlinite were reported by Sauro et al. (2014). 

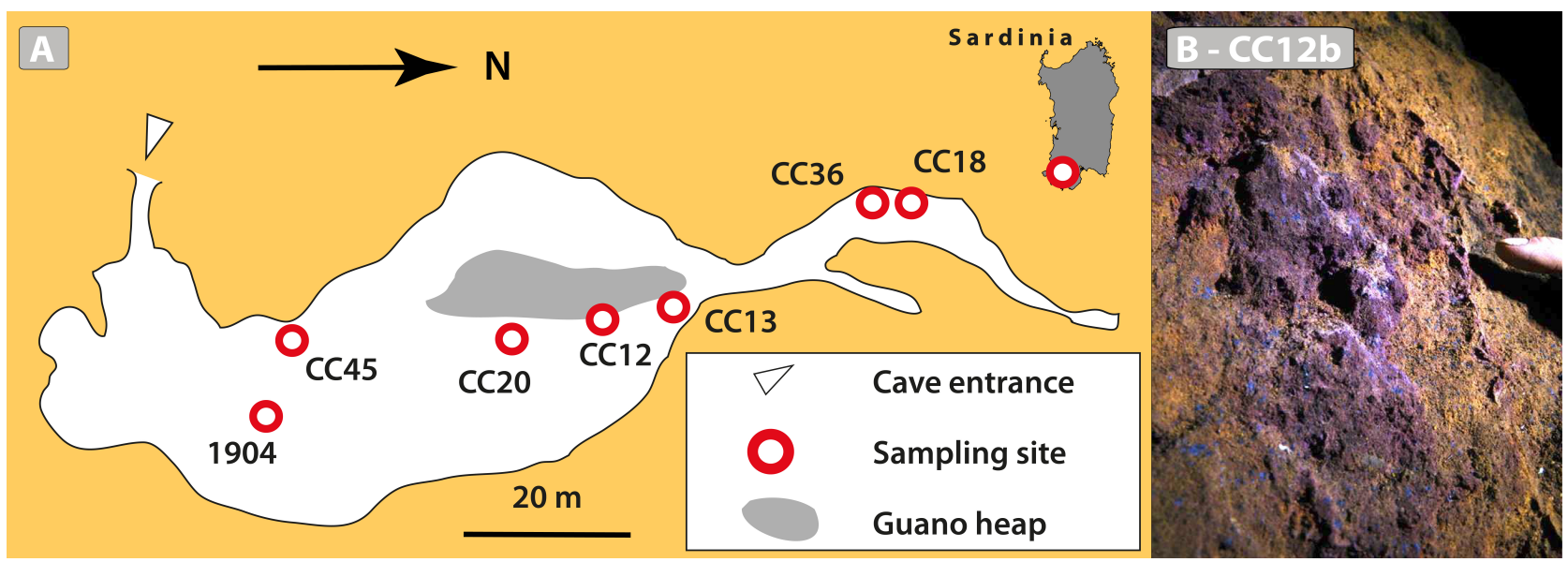

Fig. 27. A) Plan of the Corona 'e Sa Craba Cave (survey after GRSEAM caving Club, Carbonia); B) Purple-violet crusts (CC12b) with small blue fragments (Photo by L. Sanna)

\section{RESULTS: GUANO-DERIVED CAVE MINERALS}

The mineralogical results for the sampling sites on the figures of the previous section are reported in Supplementary Table. In the below reported Table 1 these results are summarized, reporting a total of 17 phosphates found in the investigated caves; these are shortly described below. Together with these phosphates, an almost ubiquitous secondary mineral produced by guano decomposition is gypsum, a sulfate. These minerals were identified by XRD analysis, with the following exceptions: Raman spectroscopy for Isturitz Cave (all samples), Raganeous Cave (RBB), and Palombara Cave (PA23); in Salnitro they were confirmed using EDAX.

Table 1. List of the 18 minerals (17 phosphates and 1 sulfate) found in the investigated caves. Chemical formulae are according to the IMA-CNMNC list of mineral names (http://nrmima.nrm.se//imalist.htm). For more details on the sampled that delivered these minerals in the different caves see Supplementary Table.

\begin{tabular}{|c|c|c|}
\hline Mineral name & Chemical formula & Cave \\
\hline Ardealite & $\mathrm{Ca}_{2}\left(\mathrm{HPO}_{4}\right)\left(\mathrm{SO}_{4}\right) \cdot 4 \mathrm{H}_{2} \mathrm{O}$ & $\mathrm{DB}, \mathrm{RC}, \mathrm{SN}, \mathrm{TC}$ \\
\hline Berlinite & $\mathrm{AlPO}_{4}$ & $\mathrm{CC}$ \\
\hline Brushite & $\mathrm{Ca}\left(\mathrm{HPO}_{4}\right) \cdot 2 \mathrm{H}_{2} \mathrm{O}$ & $\mathrm{DB}, \mathrm{RC}, \mathrm{SN}, \mathrm{TC}$ \\
\hline Crandallite & $\mathrm{CaAl}_{3}\left(\mathrm{PO}_{4}\right)\left(\mathrm{PO}_{3} \mathrm{OH}\right)(\mathrm{OH})_{6}$ & GC, MI, CA \\
\hline Fluorapatite & $\mathrm{Ca}_{5}\left(\mathrm{PO}_{4}\right)_{3} \mathrm{~F}$ & $\mathrm{DB}, \mathrm{MC}, \mathrm{AP}, \mathrm{KP}, \mathrm{LV}, \mathrm{SC}, P E, P R$ \\
\hline Hydroxylapatite & $\mathrm{Ca}_{5}\left(\mathrm{PO}_{4}\right)_{3}(\mathrm{OH})$ & $\mathrm{DB}, \mathrm{IO}, \mathrm{RC}, \mathrm{GC}, M C, \mathrm{MI}, \mathrm{AF}, \mathrm{PA}, \mathrm{MO}, \mathrm{PE}, \mathrm{SN}, \mathrm{CA}, \mathrm{PR}, \mathrm{CC}$ \\
\hline Leucophosphite & $\mathrm{KFe}^{3+}{ }_{2}\left(\mathrm{PO}_{4}\right)_{2}(\mathrm{OH}) \cdot 2 \mathrm{H}_{2} \mathrm{O}$ & $\mathrm{CC}$ \\
\hline Montgomeryite & $\mathrm{Ca}_{4} \mathrm{MgAl}_{4}\left(\mathrm{PO}_{4}\right)_{6}(\mathrm{OH})_{4} \cdot 12 \mathrm{H}_{2} \mathrm{O}$ & MI \\
\hline Newberyite & $\mathrm{Mg}\left(\mathrm{HPO}_{4}\right) \cdot 3 \mathrm{H}_{2} \mathrm{O}$ & TC \\
\hline Robertsite & $\mathrm{Ca}_{2} \mathrm{Mn}^{3+}{ }_{3}\left(\mathrm{PO}_{4}\right)_{3} \mathrm{O}_{2} \cdot 3 \mathrm{H}_{2} \mathrm{O}$ & $\mathrm{PA}, \mathrm{CC}$ \\
\hline Spheniscidite & $\left(\mathrm{NH}_{4}, \mathrm{~K}\right)\left(\mathrm{Fe}^{3+}, \mathrm{Al}\right)_{2}\left(\mathrm{PO}_{4}\right)_{2}(\mathrm{OH}) \cdot 2 \mathrm{H}_{2} \mathrm{O}$ & $\mathrm{DB}, \mathrm{JC}, \mathrm{CC}$ \\
\hline Strengite & $\mathrm{Fe}^{3+}\left(\mathrm{PO}_{4}\right) \cdot 2 \mathrm{H}_{2} \mathrm{O}$ & $\mathrm{JC}, \mathrm{CC}$ \\
\hline Taranakite & $\left(\mathrm{K}, \mathrm{NH}_{4}\right) \mathrm{Al}_{3}\left(\mathrm{PO}_{4}\right)_{3}(\mathrm{OH}) \cdot 9 \mathrm{H}_{2} \mathrm{O}$ & DB, MI, PA, PR, CC \\
\hline Variscite & $\mathrm{AlPO}_{4} \cdot 2 \mathrm{H}_{2} \mathrm{O}$ & MI, PA \\
\hline Vashegyite & $\mathrm{Al}_{11}\left(\mathrm{PO}_{4}\right)_{9}(\mathrm{OH})_{6} \cdot 38 \mathrm{H}_{2} \mathrm{O}$ & $\mathrm{CC}$ \\
\hline Vivianite & $\mathrm{Fe}^{2+}{ }_{3}\left(\mathrm{PO}_{4}\right)_{2} \cdot 8 \mathrm{H}_{2} \mathrm{O}$ & GC \\
\hline Whitlockite & $\mathrm{Ca}_{9} \mathrm{Mg}\left(\mathrm{PO}_{4}\right)_{6}\left(\mathrm{HPO}_{4}\right)$ & $\mathrm{GC}$ \\
\hline Gypsum & $\mathrm{Ca}_{2} \mathrm{SO}_{4} \cdot 2 \mathrm{H}_{2} \mathrm{O}$ & DB, IO, RC, SM, GM, MI, SN, TC \\
\hline
\end{tabular}

DB - Baradla-Domica, JC - Julio, IO - Isturitz-Oxocelhaya, RC - Raganeous, GC - Guano, SM - Saint Marcel, GM - Grosse Marguerite, MC Mescla, AP - Aramiska, KP - Karsi Podot, LV - Lekovita Voda, MI - Monte Inici, AF - Acqua Fitusa, PA - Palombara, MO - Monello, SC - Scrivilleri, PE - Personaggi, SN - Salnitro, CA - Carburangeli, PR - Pertosa-Auletta, TC - Toirano, CC - Corona 'e sa Craba. Italics indicate an uncertain presence of the mineral.

\section{Phosphate minerals}

Ardealite displays as white to yellowish, soft powder (Hill \& Forti, 1997). In Domica Cave, it is associated with gypsum, brushite, hydroxylapatite, and taranakite (Fig. 2A), as also identified by Kereskényi (2014) in this cave system. In Salnitro Cave it occurs together with brushite and gypsum (Fig. 23D), whereas at Toirano (Colombo Cave) it has been found with newberyite, brushite, and gypsum. In Raganeous Cave, all brown and white alternating layers are made of hydroxylapatite, brushite, and ardealite, but gypsum is also present (Fig. 6B). Further micro-Raman spectroscopy confirmed ardealite to be the major phase (Fig. 28). Since gypsum and brushite are isostructural, ardealite originating from an additional sulfate-ion exchange is frequently associated with these two minerals (Onac, 2012). This sulfate-calcium phosphate corresponds to the early stage of guano breakdown from the reaction of sulfuric and phosphoric acids with limestone (Hill \& Forti, 1997; Puşcaş et al., 2014). It 


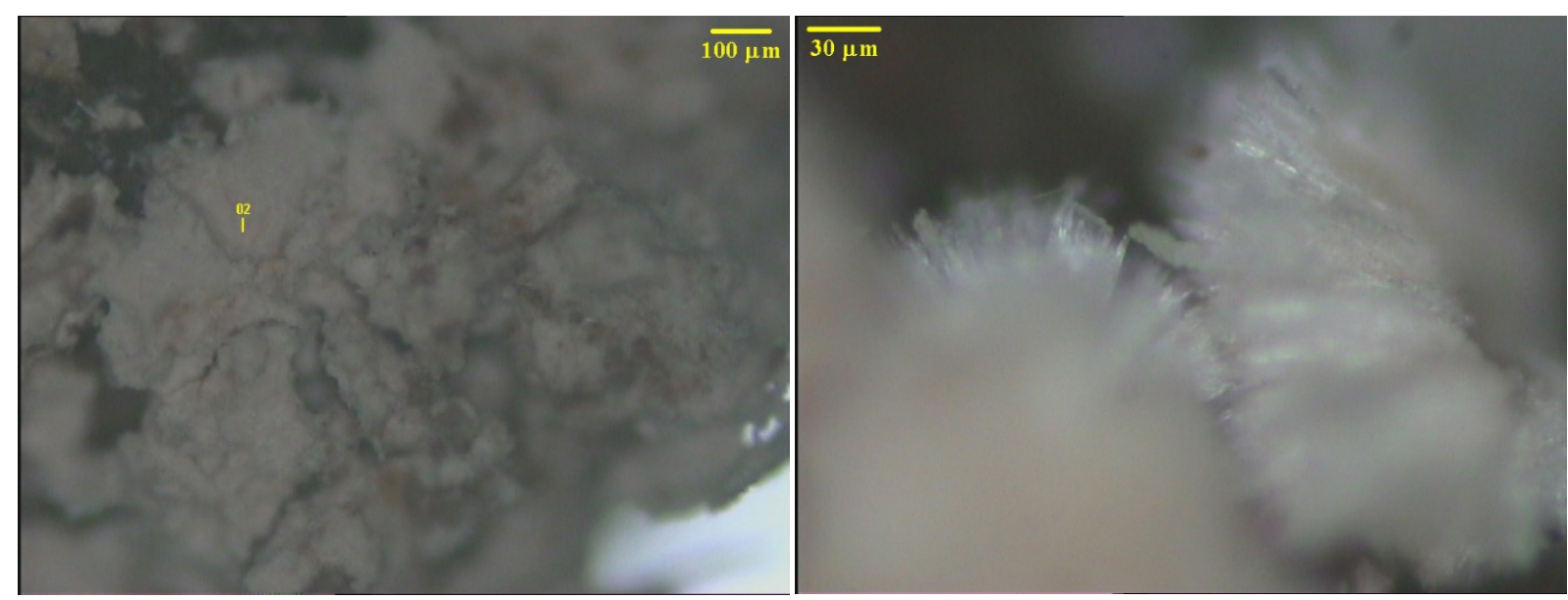

Fig. 28. Micro-photography of ardealite from Raganeous Cave (sample RBB).

is stable in slightly dry conditions and in an acidic environment, at pH of 5.7 to 6.6 (Pusscass et al., 2014), or even less than 5.5, providing sulfur is available (Marincea et al., 2004a). Ardealite may form during successive stages involving hydroxylapatite $\Rightarrow$ brushite $\Rightarrow$ ardealite $\Rightarrow$ gypsum, this last mineral depositing on the surface (Onac \& Veress, 2003; Marincea et al., 2004a; Onac et al., 2005a; Pogson et al., 2011).

The presence of Berlinite is suspected in Corona 'e Sa Craba Cave based on XRD results. Berlinite is a very rare anhydrous phosphate that requires rather high temperatures to form (over $550^{\circ} \mathrm{C}$; Muraoka \& Kihara, 1997; Onac \& White, 2003; Onac \& Effenberger, 2007). In this cave, its presence is very likely, but further investigations are needed to understand its genesis.

Brushite occurs as ivory-yellow, soft, powdery nodules (Hill \& Forti, 1997). In Salnitro Cave it occurs together with ardealite and gypsum (Fig. 23D); in Colombo Cave (Toirano) with newberyite, ardealite, and gypsum (Fig. 26B); in Raganeous Cave, with hydroxylapatite, ardealite, and some gypsum (Fig. 6B); in Baradla Cave with fluorapatite, taranakite, and gypsum. In Domica Cave, it is associated with ardealite and hydroxylapatite (Fig. 2A, 2C), where brushite occurs at the base of the guano pile, together with dominant gypsum and apatite. However, it mainly occurs as crusts at some distance below guano leachates, associated with calcite rims deposited later because of Ca oversaturation (Kettner, 1948). Brushite is often associated with gypsum, as a crust below gypsum in guano pots. Brushite, generally associated with ardealite and gypsum, is mainly present on the surface of guano piles and at the base close to the limestone contact, or as crust below guano leachates (Kettner, 1948). Brushite is a common cave mineral, stable in acidic $(\mathrm{pH}<6)$ and damp conditions (Hill \& Forti, 1997), with nucleation limits comprised between $\mathrm{pH} 5.5$ and 8 (Onac et al., 2005b). Brushite and hydroxylapatite alternatively precipitate from the same solution, with a nucleation boundary at pH 6.2-6.8, with brushite being the stable species in more acidic conditions (Puşcaş et al., 2014). It forms after reaction of phosphoric acid with limestone rock, where ammonium phosphate derives from guano breakdown, according to the following reaction (after Frost \& Palmer, 2011):

$$
\begin{gathered}
2 \mathrm{NH}_{3}+\mathrm{H}_{3} \mathrm{PO}_{4} \rightarrow\left(\mathrm{NH}_{4}\right)_{2}\left(\mathrm{PO}_{3} \mathrm{OH}\right) \\
\left(\mathrm{NH}_{4}\right)_{2}\left(\mathrm{PO}_{3} \mathrm{OH}\right)+\mathrm{Ca}^{2+}+2 \mathrm{H}_{2} \mathrm{O} \rightarrow \mathrm{Ca}\left(\mathrm{PO}_{3} \mathrm{OH}\right) \cdot 2 \mathrm{H}_{2} \mathrm{O}+2 \mathrm{NH}_{4}^{+}
\end{gathered}
$$

Crandallite was identified only in three caves. In Cocci, it is located between old guano and weathered limestone, associated with montgomeryite and hydroxylapatite (Fig. 16, Fig. 29A). It occurs as light greenish spherules in a white-yellowish-greenish material. In Guano Cave, it is located between guano and clay, and is also associated with hydroxylapatite. It was also found in Carburangeli Cave. Crandallite forms after neutralization of phosphoric acid solutions at the contact with limestone that provides $\mathrm{Ca}$, whereas Al comes from clay (Hill \& Forti, 1997).
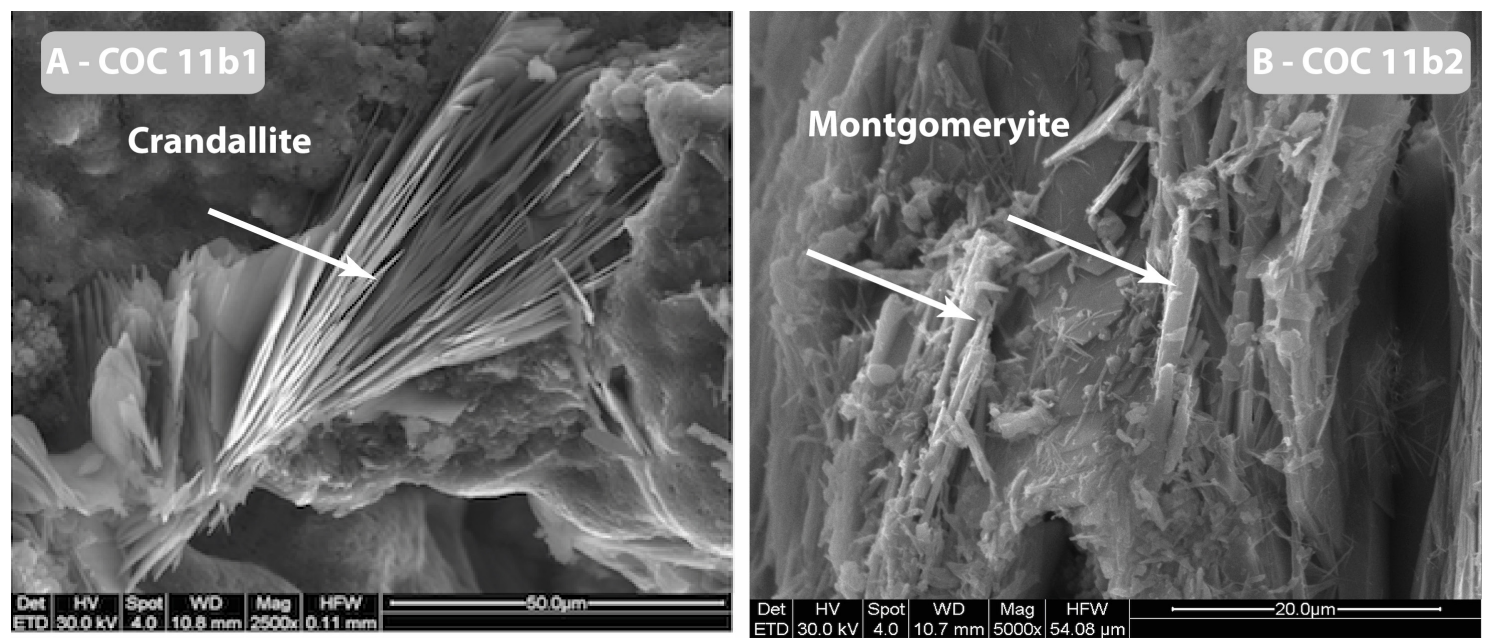

Fig. 29. SEM pictures of A) Crandallite and B) Montgomeryite from Cocci Cave (Photo by E. Galli). 
Fluorapatite is found in Baradla Cave (Fig. 2C) in a yellow layer associated with brushite and quartz, in a crust now underwater in Mescla Cave (France), and in the caves of Macedonia region (Aramiska Peštera, Karši Podot (Fig. 12), and Lekovita Voda). A carbonate-rich fluorapatite is found in Scrivilleri (Fig. 20B) and Cocci caves, Italy, as a dark brown layer associated with detrital material (quartz, calcite, goethite, kaolinite).

Fluorapatite derives from hydroxylapatite after the replacement of the hydroxyl ion by fluorine, which may be provided by the host rock (Hill \& Forti, 1997), but in our caves, it likely comes from paleontological remains (bones or teeth).

Hydroxylapatite exhibits various colors (brown, white, yellow, cream, etc.) and textures (crust, moonmilk paste, etc.). It is associated with brushite and ardealite in Domica Cave, with calcite in the "urine crust" covering ceiling cupolas of Baradla Cave and with gypsum in Cocci Cave (Fig. 16), as a stalactite in Eremita Cave (Fig. 15), and as crust associated to minor robertsite in Palombara Cave (Fig. 18C, Fig. 30). Hydroxylapatite is the most common phosphate mineral due to the neutralization of the acidic solution at the contact with limestone. It is stable at pH 6.2 - 6.6 (Hill \& Forti, 1997) and indicates a low $\mathrm{Mg}$ environment since this element inhibits the precipitation of hydroxylapatite (Chang et al., 2010).

Hydroxylapatite is often difficult to distinguish through XRD analysis from fluorapatite. In Isturitz Cave, hydroxylapatite was identified on all four samples using Raman spectroscopy. The sample from Great Pillar Cave provided spectra with the characteristic bands of calcite (at 1,085, 711, 285, and $154 \mathrm{~cm}^{-1}$ ) and of hydroxylapatite at $960 \mathrm{~cm}^{-1}$, slightly distorted and wider than normal, indicating the presence of other phosphates (Fig. 31). EDXRF shows an increase of phosphorus concentration from the calcite host rock $(3 \mathrm{mg} / \mathrm{g})$ toward the phosphatized zones (40 to $120 \mathrm{mg} / \mathrm{g}$ ). The highest concentration was found in the white weathered ring covering the inner part of the guano pot located in Lithophone site (Prieto et al., 2015).

Leucophosphite was identified only from Corona 'e sa Craba Cave. The mineral derives from interaction of bat guano solutions with iron-rich materials, such as

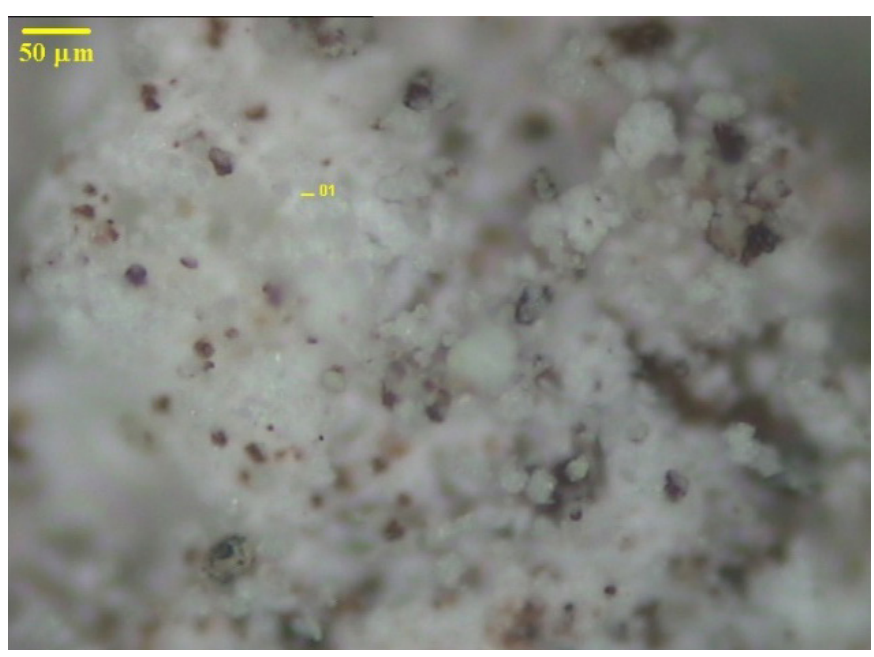

Fig. 30. Micro-photography of hydroxylapatite in Palombara Cave (PA23).

volcanic clays. It occurs together with its close relative spheniscidite, from which it is difficult to differentiate. The presence of leucophosphite was confirmed by SEM-EDS analysis showing the presence of potassium (Fig. 32).

Montgomeryite is present only in Cocci Cave, between old guano and weathered limestone, associated with crandallite and hydroxylapatite (Figs. 16, 29B). It appears as light pinkish aggregates in a white-yellowish-greenish material derived from reaction between guano and the host rock. Similar to crandallite, montgomeryite forms after neutralization of acidic solution at the contact with limestone, which supplies $\mathrm{Ca}$ and $\mathrm{Mg}$, whereas $\mathrm{Al}$ comes from clay. Due to $\mathrm{Ca}$ and $\mathrm{Mg}$ leaching, it is metastable and converts into crandallite and eventually to variscite (Hill \& Forti, 1997).

Newberyite has been discovered in Grotta del Colombo, part of the Toirano cave complex (Liguria). It was found together with gypsum as a hard-yellowish crust on old guano heaps in a large entrance hall in open communication with the outside atmosphere (Fig. 26B). This mineral is more typical of caves of a warm and dry climate (Hill \& Forti, 1997). However, in Toirano, the genesis of this mineral likely comes from the interaction of phosphates with $\mathrm{Mg}$ provided by the disaggregation of dolomitic host rock or by seepage from this rock, whereas air exchanges with the atmosphere provide seasonal dry conditions.

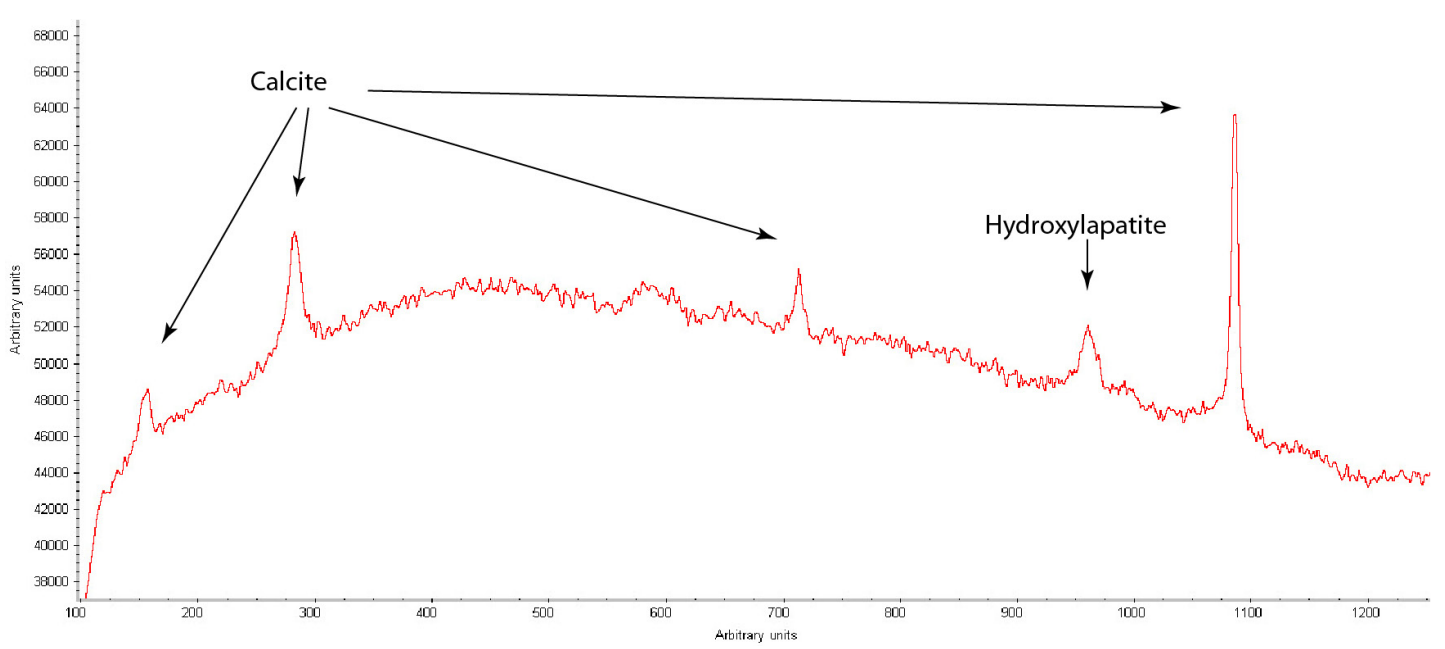

Fig. 31. Raman spectra from Isturitz Cave, France (Prieto et al., 2015). 


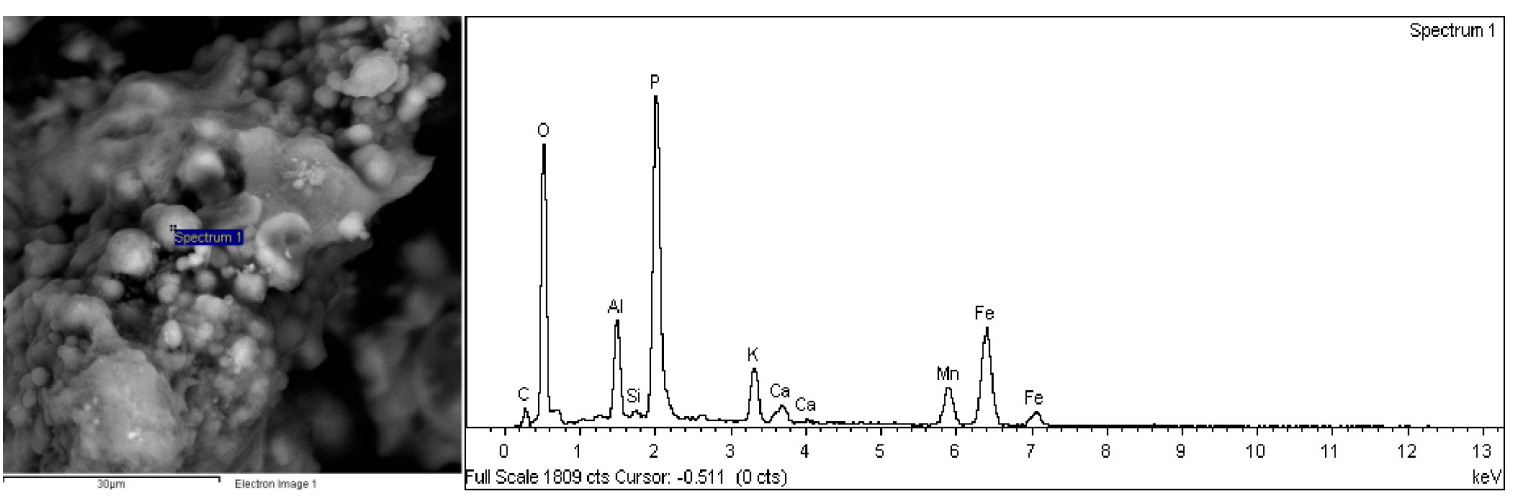

Fig. 32. SEM-EDS spectra of spheniscidite in Corona 'e sa Craba cave. Potassium (K) indicates the presence of a minor leucophosphite phase (Baldoni et al., 2013).

Robertsite is a calcium-manganese phosphate deriving from the reaction with host rock that provides the metallic ions. Robertsite is generally associated to the weathering of pegmatitic deposits. Its occurrence in caves is very rare, only reported in Puerto Princesa Underground River, Philippines (De Vivo et al., 2013), and in Corona 'e sa Craba Cave, Italy (Sauro et al., 2014). In Palombara Cave, robertsite is a minor compound associated with hydroxylapatite (Fig. 18C). Mn is likely related to rising fluids, since Palombara is a hypogene thermal cave. The presence of Pararobertsite was suspected from XRD. Further micro-Raman spectroscopy showed that manganese is indeed present in oxides (jacobsite or todorokite), but the Mn phosphate pararobertsite could not be confirmed because of the difficulty to distinguish its spectra from robertsite and hydroxylapatite.

Spheniscidite is found in Baradla Cave, in a white laminated layer near the bottom of a guano accumulation, close to the contact with limestone and clay substratum (Fig. 2C). It is associated with taranakite, quartz, and illite. In Corona 'e sa Craba Cave, small crystals of spheniscidite $(10 \mu \mathrm{m})$ are forming purple-violet crusts that cover the walls close to fresh guano deposits (Fig. 27B). In Julio Cave, it crops out along with strengite as thick grey deposits derived from the weathering of fluvial silts. The chemical formula of spheniscidite is very close to that of leucophosphite (the latter containing Al and $\mathrm{NH}_{4}$ ). The breakdown of bat urea first produces gaseous ammonia $\left(\mathrm{NH}_{3}\right)$, which in turn produces in the presence of water, the very soluble ammonium ion $\left(\mathrm{NH}_{4}^{+}\right)$. Spheniscidite forms from the reaction of ammonium-rich fresh guano leachates with clay sediments containing $\mathrm{Fe}$, namely illite-group minerals. These three occurrences of spheniscidite are new additions to the first mention reported from a Sardinian cave (Sauro et al., 2014). This mineral is relatively soluble; therefore, it only occurs under conditions allowing its preservation as crusts in a dry environment (Corona 'e sa Craba Cave) or in places where drainage is low (Baradla, Julio).

Strengite has been found in Corona 'e Sa Craba and Julio caves. It derives from the interaction between acidic guano leachates and detrital material (clay, fluvial silts) or host rock providing Fe. A partial substitution of $\mathrm{Fe}$ by $\mathrm{Al}$ produces $\mathrm{Al}$-rich strengite, a rare occurrence, which is not recognized by the IMA as a bona fide mineral (Onac et al., 2005a).
Taranakite appears as a soft flour-like white powder, and as nodules in clay (Hill \& Forti, 1997). It occurs with calcium phosphates (brushite and ardealite), with gypsum in Domica (Fig. 2A, C) and Eremita caves (Fig. 15), with spheniscidite in Baradla Cave, and is always associated with clay material: illite in Baradla Cave; kaolinite in Palombara Cave (Fig. 18B); river sediments in Pertosa-Auletta cave system (Fig. 25C); kaolinite and montmorillonite in Eremita Cave. Taranakite forms in damp (Hill \& Forti, 1997) and slightly acidic conditions at pH $5.7-6.1$ (Onac, 1996; Puşcas et al., 2014) from the reaction of guanorelated phosphate solutions with clay substratum containing illite or kaolinite that provide $\mathrm{K}^{+}$and $\mathrm{Al}^{3+}$.

In Palombara Cave (Sicily), Variscite occurs as an intense purple layer sandwiched below old guano and above white taranakite; this last mineral rests on clay substratum that contains quartz and kaolinite (Fig. 18B). In Eremita Cave, variscite is associated with gypsum and occurs as a white layer above a yellow accumulation of taranakite and gypsum, with the latter one resting on clay substratum that contains montmorillonite and kaolinite (Fig. 15). Variscite forms from guano-related phosphate leachates reacting with clays such as kaolinite that provide $\mathrm{Al}^{3+}$, and where $\mathrm{K}^{+}$ and $\mathrm{Fe}^{2+}$ are not available.

Vashegyite is present in Corona 'e Sa Craba Cave. It is a rare cave mineral resulting from the interaction of bat guano solutions with clays providing $\mathrm{Al}$, in slightly acidic and permanent wet conditions (Forti et al., 2000; Onac et al., 2006b).

Vivianite is suspected to be present in Guano Cave. It is a rare cave mineral, mentioned first in Niah Great Cave, Malaysia (Bridge \& Robinson, 1983), then in Megali Grava Cave, Greece (Theodorou et al., 2004) and Grotta Castellana, Italy (Hill \& Forti, 1997). There, vivianite derives from the reaction of guano with "terra rossa" in a strong reducing environment, due to presence of coal and organic matter. We speculate similar conditions in Guano Cave.

Whitlockite is a rare mineral first described in a cave at Sebdou, Algeria (Bannister \& Bennett, 1947) and in El Capote Cave, Mexico (Peréz Martínez \& Wiggen, 1953). It constitutes various speleothems as isolated aggregates or earthy material (CAMIDA, 2018). We found whitlockite only in Guano Cave, on the weathered layer of a dolomitic wall. It is associated with hydroxylapatite and possibly vivianite (see above), together with muscovite, quartz, and birnessite (Mn 
oxide of $\mathrm{Ca}-\mathrm{Na}$ ). The three last minerals are partly or entirely allogenic. Whitlockite derives from interaction of bat guano solutions with carbonate walls providing $\mathrm{Ca}$ and $\mathrm{Mg}$. Alternatively, it could form from the dissolution of apatite and subsequent precipitation in the presence of low Ca concentration solutions (Peréz Martínez \& Wiggen, 1953; Bridge \& Robinson, 1983; Onac et al., 2009).

\section{Sulfates}

Gypsum is a common sulfate cave mineral, often related to bat guano deposits, the oxidation of pyrite from bedrock or sediments, or to sulfuric acid speleogenesis (De Waele et al., 2016). In the case of bat guano deposits, it occurs as crystalline crusts due to evaporation on the surface, or as interbedded lenses, pure or associated with other minerals. It forms from sulfuric acid solutions originating from the decaying guano that reacts with drippings providing carbonates in solution. As crystalline crust, it is present in yellow crystalline masses on old guano in Saint-Marcel Cave (Fig. 8C) and Raganeous Cave (Fig. 6C), in Colombo Cave associated with newberyite (Fig. 26B), in a black crust on a wall in Salnitro Cave associated to hydroxylapatite, in Eremita Cave as soft microcrystalline deposits on the surface of guano (Fig. 15), in Cocci Cave as crusts or transparent crystals. The thick white crust covering limestone blocks nearby old guano in Rhinolophes Chamber (Isturitz Cave; Fig. 5B), provided characteristic Raman spectra of gypsum. EDXRF shows that phosphorus concentration is here limited to $14 \mathrm{mg} / \mathrm{g}$, whereas it reaches $40-100 \mathrm{mg} / \mathrm{g}$ in the uppermost dark phosphate crust directly exposed to bat drops (Prieto et al., 2015).
The second type of gypsum occurrence is that of layers of various thickness and purity. In Raganeous, Baradla, and Domica caves, as white paste, alone (Ba 4d), or associated with ardealite and brushite (Pr. B, RBB) (Fig. 2A). In Eremita (Eremita 3, 4, and ERE 14; Fig. 15) and Grosse Marguerite (Fig. 9B), pure gypsum constitutes a layer of soft yellow or compact white material, respectively.

\section{Radiocarbon dating of guano piles}

Thirty-two radiocarbon dates were performed on six guano piles, with 4 of them carried out along a vertical profile (Table. 2). Raganeous Cave shows a continuous deposit of about 1000 years. The oldest age at $\mathrm{AD} 1004$, corresponds to the depth $1.72 \mathrm{~m}$. The sample taken at $0.48 \mathrm{~m}$ deposited at $\mathrm{AD} 1843$. The oldest cone was probably entirely mined for fertilizer around AD 1349 (according to the age of the wood torch found at a depth of $1.5 \mathrm{~m}$ ), whereas the present cone has formed since. In Domica Cave, Prales guano pile is still actively accumulating, as compared to pictures taken about 65 years ago (Kettner, 1948). The two cores reaching the bottom date back to AD 1351 and AD 1102 respectively. Palmový Háj has a similar age at $1 \mathrm{~m}$ depth (AD 990; Krištůfek et al., 2008), whereas most of the accumulation between $60 \mathrm{~cm}$ and the subsurface is bracketed between AD 1654 and AD 1831. In Saint-Marcel, the date (1916 BC) corresponds to the surface of the guano accumulation, whereas in Baradla (281 BC) it corresponds to the bottom. For Grosse Marguerite, radiocarbon dates yielded calibrated ages comprised between 5040 BC and $2741 \mathrm{BC}$. The central white unit, made of pure gypsum, is framed between $4524 \mathrm{BC}$ and $2889 \mathrm{BC}$.

Table 2. Radiocarbon dating of guano, including previous studies in Saint-Marcel (Dodelin, unpubl.) and Domica G1-5 samples (Krištůfek, 2008).

\begin{tabular}{|c|c|c|c|c|c|c|c|c|c|c|}
\hline Cave & Site & Lab. & Lab. no. & $\begin{array}{c}\text { Sample } \\
\text { no. }\end{array}$ & $\begin{array}{l}\text { Dist. from } \\
\text { surface } \\
\text { (cm) }\end{array}$ & $\begin{array}{l}\text { Conventional } \\
\text { radiocarbon } \\
\text { age (AMS) }\end{array}$ & $\begin{array}{c}\text { Median } \\
\text { Probability } \\
\text { Cal year } \\
\text { AD/BC }\end{array}$ & \multicolumn{2}{|c|}{$\begin{array}{l}\text { cal } \mathrm{AD} / \mathrm{BC} \\
\text { age ranges }\end{array}$} & $\begin{array}{l}\text { Probability } \\
\text { distribution }\end{array}$ \\
\hline \multirow{11}{*}{ Raganeous } & \multirow{11}{*}{$\begin{array}{l}\text { Guano } \\
\text { hill (base } \\
\text { of shaft) }\end{array}$} & \multirow{11}{*}{$\begin{array}{c}\text { Poznań } \\
\text { Radiocarbon } \\
\text { Laboratory }\end{array}$} & Poz-72000 & $\begin{array}{l}\text { RAG- } \\
\text { C3-S4 }\end{array}$ & 48,5 & $85 \pm 30 \mathrm{BP}$ & 1843 & 1809 & 1926 & 0.734 \\
\hline & & & Poz-59140 & $\begin{array}{l}\text { RAG- } \\
\text { C3-S3 }\end{array}$ & 76,5 & $200 \pm 30 \mathrm{BP}$ & 1771 & 1730 & 1809 & 0.567 \\
\hline & & & Poz-71999 & $\begin{array}{l}\text { RAG- } \\
\text { C3-S3 }\end{array}$ & 79.5 & $175 \pm 30 \mathrm{BP}$ & 1770 & 1725 & 1815 & 0.556 \\
\hline & & & Poz-59141 & $\begin{array}{l}\text { RAG- } \\
\text { C3-S2 }\end{array}$ & 72,5 & $140 \pm 30 \mathrm{BP}$ & 1807 & 1798 & 1891 & 0.383 \\
\hline & & & Poz-71998 & $\begin{array}{l}\text { RAG- } \\
\text { C3-S2 }\end{array}$ & 99,5 & $180 \pm 30 \mathrm{BP}$ & 1770 & 1726 & 1814 & 0.569 \\
\hline & & & Poz-71997 & $\begin{array}{l}\text { RAG- } \\
\text { C3-S2 }\end{array}$ & 129,5 & $290 \pm 30 \mathrm{BP}$ & 1566 & 1493 & 1601 & 0.675 \\
\hline & & & Poz-59142 & $\begin{array}{l}\text { RAG- } \\
\text { C3-S1 }\end{array}$ & 125,5 & $260 \pm 25 \mathrm{BP}$ & 1647 & 1630 & 1668 & 0.679 \\
\hline & & & Poz-72060 & $\begin{array}{l}\text { RAG- } \\
\text { C3-S1 }\end{array}$ & 149,5 & $305 \pm 30 \mathrm{BP}$ & 1562 & 1488 & 1603 & 0.745 \\
\hline & & & Poz-62932 & $\begin{array}{l}\text { Wood } \\
\text { torch }\end{array}$ & 158.5 & $620 \pm 30 \mathrm{BP}$ & 1349 & 1292 & 1399 & 1.000 \\
\hline & & & Poz-59143 & $\begin{array}{l}\text { RAG- } \\
\text { C3-S1 }\end{array}$ & 169,5 & $1015 \pm 25 \mathrm{BP}$ & 1013 & 978 & 1042 & 0.981 \\
\hline & & & Poz-72061 & $\begin{array}{l}\text { RAG- } \\
\text { C3-S1 }\end{array}$ & 171,5 & $1030 \pm 30 \mathrm{BP}$ & 1004 & 962 & 1041 & 0.965 \\
\hline Saint-Marcel & $\begin{array}{c}\text { Bat } \\
\text { gallery }\end{array}$ & $\begin{array}{c}\text { Centre de } \\
\text { datation } \\
\text { radiocarbone } \\
\text { (CDRC), Lyon }\end{array}$ & Ly-16803 & SM1 & Surface & $3565 \pm 30 \mathrm{BP}$ & 1916 BC & $\begin{array}{c}1982 \\
\mathrm{BC}\end{array}$ & $\begin{array}{c}1872 \\
\mathrm{BC}\end{array}$ & 0.834 \\
\hline
\end{tabular}




\begin{tabular}{|c|c|c|c|c|c|c|c|c|c|c|}
\hline Baradla & $\begin{array}{c}\text { Libanon- } \\
\text { Hegy }\end{array}$ & $\begin{array}{l}\text { ARTEMIS } \\
\text { (LMC14, } \\
\text { Saclay) }\end{array}$ & SAC_45654 & BA4 3-4 & $\approx 50$ & $2205 \pm 40 \mathrm{BP}$ & $281 \mathrm{BC}$ & $\begin{array}{l}379 \\
\mathrm{BC}\end{array}$ & $\begin{array}{l}177 \\
\mathrm{BC}\end{array}$ & 1.000 \\
\hline \multirow{10}{*}{ Domica } & \multirow{5}{*}{$\begin{array}{l}\text { Palmový } \\
\text { Háj. } \\
\text { Guano } \\
\text { hill }\end{array}$} & \multirow{5}{*}{ Poznań RL } & Poz-18867 & G1 & $0-3$ & $109.51 \pm 0.35 \mathrm{pMC}$ & $\begin{array}{c}\text { Modern (Post } \\
\text { to } 1957 \mathrm{AD})\end{array}$ & \multicolumn{2}{|c|}{$>1957 \mathrm{AD}$} & \\
\hline & & & Poz-18868 & G2 & $0-3$ & $120 \pm 30 \mathrm{BP}$ & 1831 & 1801 & 1939 & 0.659 \\
\hline & & & Poz-18869 & G4 & $0-3$ & $135 \pm 30 \mathrm{BP}$ & 1813 & 1799 & 1892 & 0.414 \\
\hline & & & Poz-18870 & G3 & $60-65$ & $250 \pm 30 \mathrm{BP}$ & 1654 & 1626 & 1679 & 0.596 \\
\hline & & & Poz-18871 & G5 & $100-105$ & $1055 \pm 30 \mathrm{BP}$ & 990 & 945 & 1024 & 0.883 \\
\hline & \multirow{3}{*}{$\begin{array}{l}\text { Palmový } \\
\text { Háj. } \\
\text { Guano } \\
\text { hill }\end{array}$} & \multirow{2}{*}{ ARTEMIS } & SAC_45652 & PH 56-57 & 18 & $185 \pm 30 \mathrm{BP}$ & AD 1770 & 1726 & 1813 & 0,578 \\
\hline & & & SAC_45653 & PH 20-21 & 54 & $155 \pm 30 \mathrm{BP}$ & AD 1776 & 1718 & 1784 & 0,359 \\
\hline & & Poznań RL & $\begin{array}{l}\text { Poz\#2- } \\
79326\end{array}$ & PH 1-2 & 73 & $250 \pm 27 \mathrm{BP}$ & AD 1654 & 1631 & 1675 & 0,658 \\
\hline & \multirow{2}{*}{$\begin{array}{c}\text { Prales } \\
\text { Chamber. } \\
\text { Guano } \\
\text { hill }\end{array}$} & ARTEMIS & SAC_45651 & PR1 4-6 & 35 & $915 \pm 30 \mathrm{BP}$ & AD 1102 & 1030 & 1188 & 1.000 \\
\hline & & Poznań RL & Poz-79327 & PR2 4-6 & 59 & $625 \pm 26 \mathrm{BP}$ & AD 1351 & 1337 & 1398 & 0,606 \\
\hline \multirow{9}{*}{$\begin{array}{c}\text { Grosse } \\
\text { Marguerite }\end{array}$} & \multirow{9}{*}{$\begin{array}{l}\text { Guano } \\
\text { hill (top of } \\
\text { gallery) }\end{array}$} & \multirow{6}{*}{ ARTEMIS } & SAC_46850 & GM2 3-4 & 3,5 & $4145 \pm 30 \mathrm{BP}$ & $2741 \mathrm{BC}$ & $\begin{array}{c}2825 \\
\mathrm{BC}\end{array}$ & $\begin{array}{c}2625 \\
\mathrm{BC}\end{array}$ & 0.805 \\
\hline & & & SAC_46851 & $\begin{array}{c}\text { GM2 10- } \\
11\end{array}$ & 10,5 & $4260 \pm 40 \mathrm{BP}$ & $2889 \mathrm{BC}$ & $\begin{array}{c}2937 \\
\mathrm{BC}\end{array}$ & $\begin{array}{c}2854 \\
\text { BC }\end{array}$ & 0.754 \\
\hline & & & SAC_45658 & $\begin{array}{c}\text { GM2 22- } \\
23\end{array}$ & 22,5 & $5690 \pm 40 \mathrm{BP}$ & $4524 \mathrm{BC}$ & $\begin{array}{c}4619 \\
\mathrm{BC}\end{array}$ & $\begin{array}{c}4450 \\
\mathrm{BC}\end{array}$ & 0.956 \\
\hline & & & SAC_45657 & $\begin{array}{c}\text { GM2 32- } \\
33\end{array}$ & 32,5 & $5710 \pm 45 \mathrm{BP}$ & $4551 \mathrm{BC}$ & $\begin{array}{c}4625 \\
\mathrm{BC}\end{array}$ & \begin{tabular}{c|}
4458 \\
$\mathrm{BC}$
\end{tabular} & 0.860 \\
\hline & & & SAC_45656 & $\begin{array}{c}\text { GM2 } 52- \\
53\end{array}$ & 52,5 & $6110 \pm 40 \mathrm{BP}$ & 4986 BC & $\begin{array}{c}5068 \\
\mathrm{BC}\end{array}$ & \begin{tabular}{|c|}
4892 \\
$\mathrm{BC}$
\end{tabular} & 0.936 \\
\hline & & & SAC_45655 & $\begin{array}{c}\text { GM2 58- } \\
59\end{array}$ & 58,5 & $6075 \pm 35 \mathrm{BP}$ & $5040 \mathrm{BC}$ & $\begin{array}{c}5208 \\
\mathrm{BC}\end{array}$ & $\begin{array}{c}4942 \\
\mathrm{BC}\end{array}$ & 1.000 \\
\hline & & \multirow{3}{*}{ ARTEMIS } & SAC_46849 & GM $13-4$ & 3,5 & $4130 \pm 30 \mathrm{BP}$ & $2725 \mathrm{BC}$ & $\begin{array}{c}2780 \\
\mathrm{BC}\end{array}$ & $\begin{array}{c}2617 \\
\mathrm{BC}\end{array}$ & 0.664 \\
\hline & & & SAC_45660 & $\begin{array}{c}\text { GM1 13- } \\
14\end{array}$ & 13,5 & $4230 \pm 60 \mathrm{BP}$ & 2795 BC & $\begin{array}{c}2932 \\
\text { BC }\end{array}$ & $\begin{array}{c}2620 \\
\mathrm{BC}\end{array}$ & 0.989 \\
\hline & & & SAC_45659 & $\begin{array}{c}\text { GM1 31- } \\
32\end{array}$ & 31,5 & $5750 \pm 40 \mathrm{BP}$ & $4601 \mathrm{BC}$ & $\begin{array}{c}4701 \\
\mathrm{BC}\end{array}$ & $\begin{array}{c}4500 \\
\mathrm{BC}\end{array}$ & 1.000 \\
\hline
\end{tabular}

\section{Acidity of the decaying guano}

We measured two profiles along guano accumulations in Domica Cave in Prales (PR2) and Palmový Háj (PH) (Fig. 33). In Prales the guano is still actively accumulating; its basal layer was dated at about $\mathrm{AD}$ 1351. The $\mathrm{pH}$ profile shows a continuous decrease, from 4.3 to 3.7 , with a slight increase at the very bottom. Palmovy Háj, on the contrary, is not active anymore, showing an oscillation of $\mathrm{pH}$ in a narrow range between 3.9 and 3.5. No trend associated to depth-age is visible.

\section{DISCUSSION}

\section{Guano-related mineral genesis}

The presence of seventeen different phosphate minerals and gypsum in the twenty-two investigated cave systems is related to the presence of different physico-chemical conditions and the availability of different elements in the host rock (Fig. 34). Guano can slowly transform by itself, but its leachates also react with the bedrock and minerals hosted therein (e.g., sulfides such as pyrite), clays, and airborne material. The processes leading to the formation and precipitation of these minerals are: acid digestion, microbially-driven organic decay, self-combustion (since guano decay is an exothermic reaction), and evaporation.

In limestone caves and in acidic, wet and fresh guano deposits, the typical mineral association is composed of brushite, ardealite, and gypsum. These

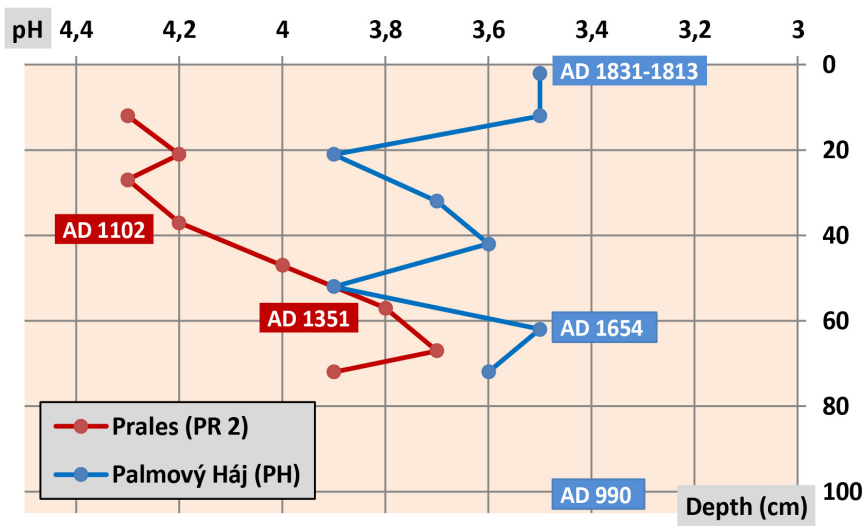

Fig. 33. $\mathrm{pH}$ decreases along the PR2 and $\mathrm{PH}$ cores in the guano hill of Prales Chamber and Palmový Háj, Domica Cave, with indication of calibrated ${ }^{14} \mathrm{C}$ ages.

are rather soluble minerals which often do not persist over long periods of times (as guano decomposes), and as such they are found only in rather fresh deposits. Such conditions exist in Salnitro and Toirano caves, and in Saint-Marcel and Raganeous caves. In this last cave, the low maturation of guano is interpreted to be the result of permanent airflow between the entrances that maintain dry conditions, which slows down mineralization. Often, hydroxylapatite also forms under similar conditions, with fluorapatite occurring where guano is in contact with skeleton remains, such as in the three Macedonian caves. These two minerals, which are typical for more neutral condition, due to the buffering effect of the limestone, are the most abundant phosphates found 
in guano pots, or as crusts on the limestone walls and roofs. In some caves, these are the only phosphates (e.g., Isturitz, Acqua Fitusa, Monello, Scrivilleri, Personaggi). Their lower solubility makes them the most stable mineral phases during the initial guano digestion. In warmer and drier cave conditions, when bedrock is dolomitic, such as Toirano, newberyite has been found. The presence of gypsum on top of guano deposits is related to the evaporation of water, and these gypsum layers can become rather thick if the evaporative conditions prevail over long-time periods. This is the case for the Grosse Marguerite Cave (where the $15 \mathrm{~cm}$-thick gypsum layer is about 5,000 years old), and in Eremita Cave in Sicily.

If the guano deposits and its leachates are in contact with clays (as interlayers in the limestone or as residual sedimentary deposits (both allochthonous and autochthonous), taranakite, variscite, and the rare montgomeryite and crandallite (e.g., Cocci Cave in Sicily) can typically form (Fig. 35). This often occurs in slightly more acidic conditions, because of the lower buffering effect of the carbonate rock. Both taranakite and variscite are among the most stable phosphates in the cave environment, and once formed they are often preserved over long periods of time, even in rather wet conditions (e.g., Pertosa Cave, Palombara and Eremita caves). Instead, the presence of sulfides, mainly pyrite, in the bedrock will trigger the formation of (Al-rich) strengite and leucophosphite. In a fresh guano environment, spheniscidite can also form in the presence of pyrite or other sulfides such as galena (e.g., Corona 'e sa Craba, Baradla, and Julio caves). Corona 'e $\mathrm{Sa}$ Craba is a uniquely rich mineralogical environment, as the cave develops in a quartz vein in close contact with dolomitic and sulfide-rich limestones, thus causing the formation of phosphates such as robertsite, spheniscidite, leucophosphite, vashegyite, strengite, and possibly the rare berlinite. Robertsite has also been found in Palombara Cave, and if combined with some geomorphological indicators, this mineral might point to a hypogene origin of this cave.

A mature occurrence of mineralized guano normally leads to the formation of apatite-group minerals, occurring in well-crystallized forms, even layered stalagmites and stalactites in Eremita Cave, Cocci Abyss, Sicily (D’Angeli et al., 2018).

\section{Survival of the very soluble gypsum}

As most sulfates, gypsum is rather soluble and therefore, in very wet cave environments it can be dissolved. However, gypsum can be present where it

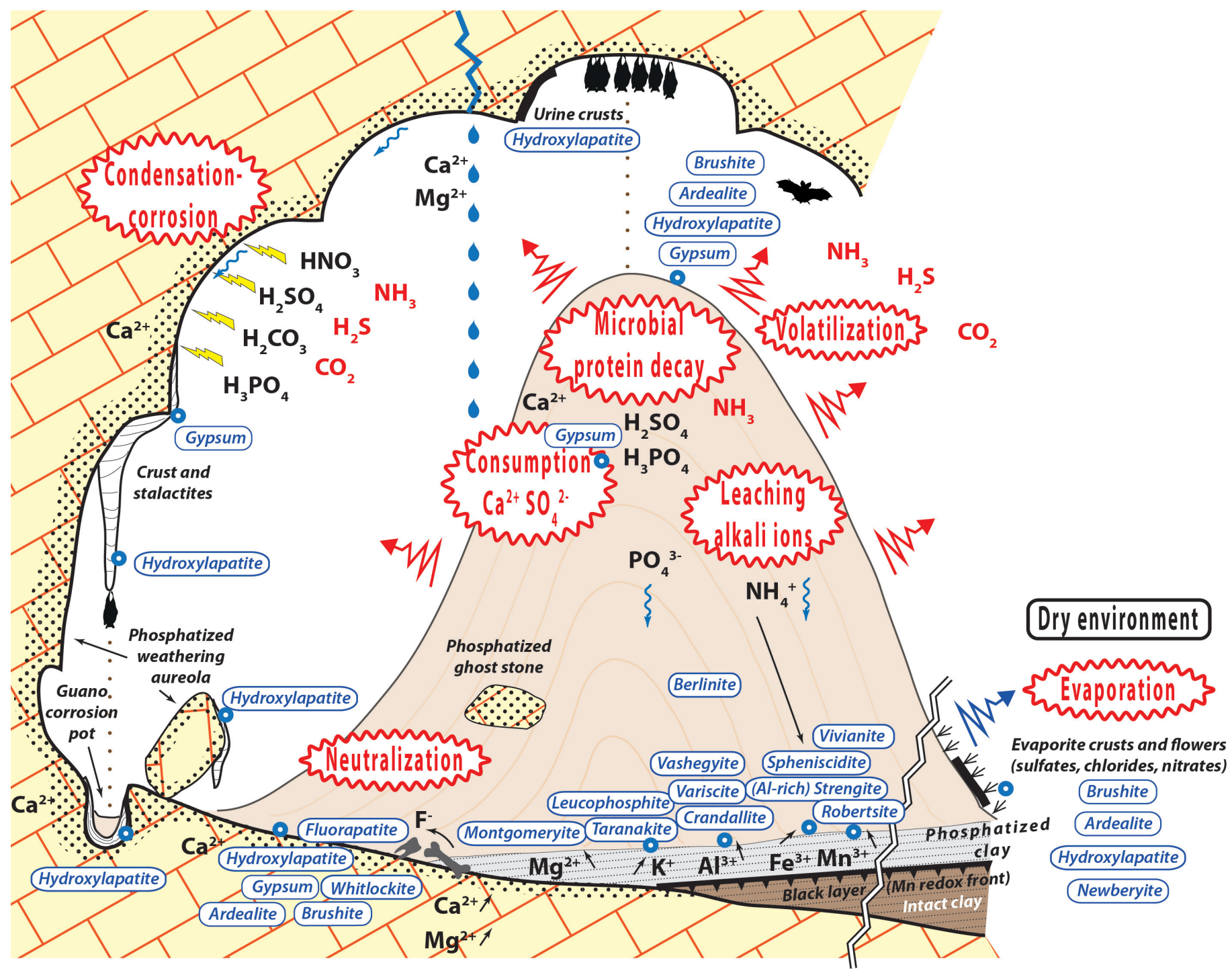

Fig. 34. Idealized diagram showing the occurrence of the eighteen guano-derived minerals in the studied cave environments and the processes involved in their formation. 
forms from fresh guano decaying, in the upper part of guano piles which are drier. A typical occurrence is on the surface of a guano heap, especially at a distance from the dripping point location, where evaporation dries up the guano material, attracts the dissolved sulfates by capillary flow, and allows the crystallization and the conservation of sulfates at the interface between wet and dry areas. Providing no leaching occurs, gypsum can even be present at the wet base of guano deposits such as in DomicaBaradla. Gypsum can also persist in areas protected from dripping and leaching (Vanara, 2015).

\section{Age and research potential of guano deposits}

Some caves host long records covering the last millennium, such as in Raganeous, and possibly the two accumulations in Domica (Palmový Háj and Prales).
Older records are available in Grosse Marguerite (2741 to $5040 \mathrm{BC}$ ), and possibly also for Saint-Marcel, older than 1916 BC, and Baradla, younger than 281 BC. These deposits kept their original stratigraphy and were only affected by strong compaction due to their own weight. High-resolution dating would help to show their continuity or their gaps resulting from temporary abandonment of the shelter by bats, generally in relationship with climatic and/or environmental changes. However, the regular laminated guano accumulation in Raganeous was demonstrated to be continuous over the last millennium (Bentaleb et al., in prep.). Since guano deposits can be used as paleoenvironmental proxy, their potential for reconstruction based on the layered records, stable isotopes, pollen, and possibility of dating is very important (Onac et al., 2015; Cleary et al., 2017).

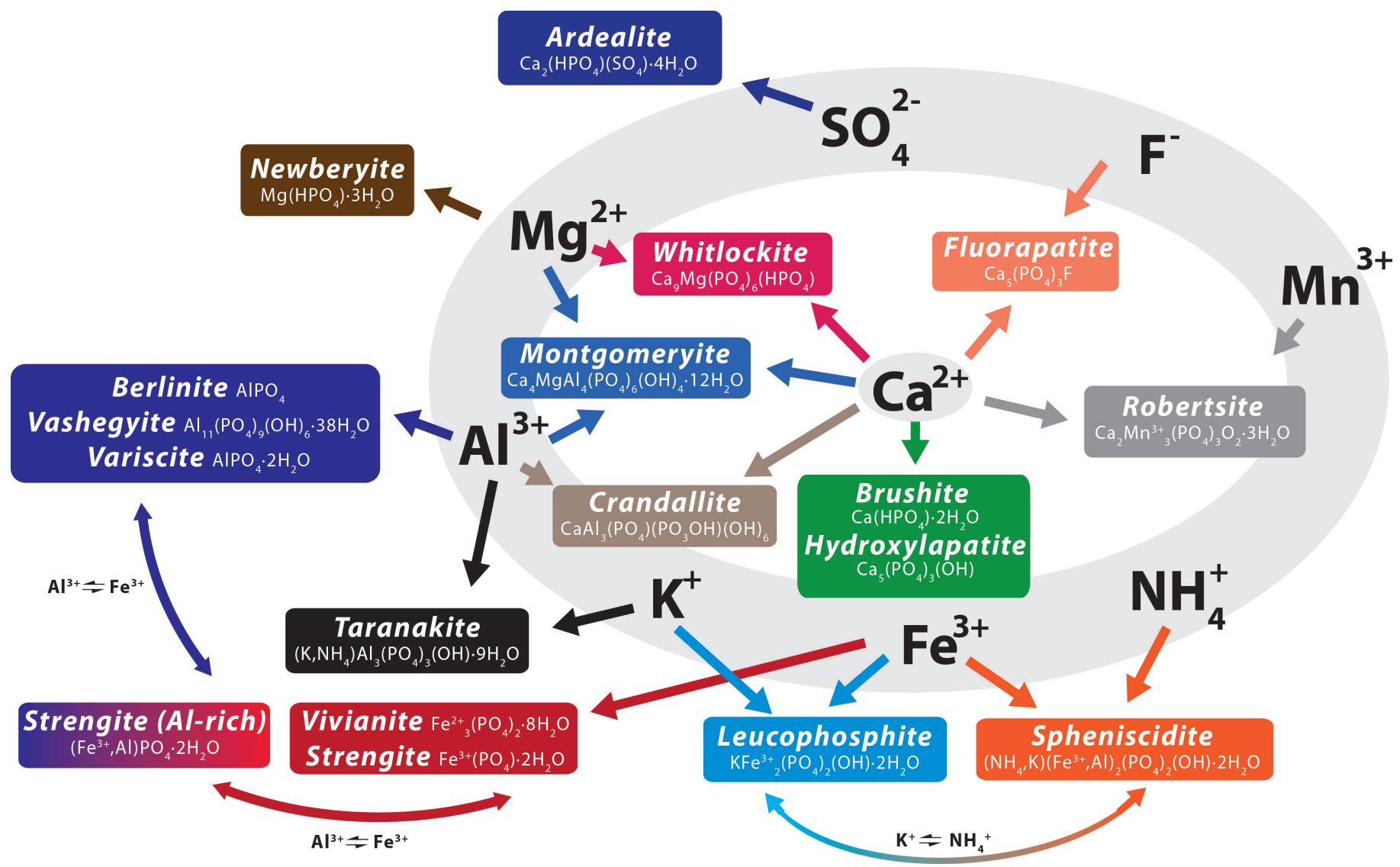

Fig. 35. Composition and inter-relationships of the 17 phosphate minerals according to the contribution of secondary components (Ca-Mg from host rock; Sulfate from organic decay or from pyrites; $\mathrm{NH}_{4}$ from organic decay; $\mathrm{F}$ from bones or teeth; Al-K-Fe-Mn from detrital clay).

\section{Strong acidity of the decaying guano and environmental conditions for mineral genesis}

Although fresh guano is slightly alkaline (Audra et al., 2016), its organic decay progressively delivers acids (nitric, sulfuric, phosphoric, and carbonic) that contribute to the increase of acidity with $\mathrm{pH}$ as low as 2-4 (Martini, 1993, 2000; Hill \& Forti, 1997, 2001). This acidic environment contributes to the genesis of minerals, mainly phosphates but also some sulfates and sometimes nitrates, through the interaction with organic matter (e.g., $\mathrm{NH}_{4}^{+}$), with solutes from dripping (e.g., $\mathrm{Ca}, \mathrm{Mg}$ ), with the carbonate host rock (calcite or dolomite), and with detrital material providing Al, $\mathrm{Fe}, \mathrm{K}, \mathrm{Mg}, \mathrm{Mn}$, etc. In Domica Cave, we observed that the $\mathrm{pH}$ in the active guano pile decreases almost continuously with depth, where the 600-years old mineralized guano shows $\mathrm{pH}$ of 3.7. The slight increase to 3.9 at the bottom could be interpreted as the beginning of acid solutions neutralization at the proximity with the limestone pavement. On the contrary, in the inactive and already partly mineralized guano pile, the $\mathrm{pH}$ is very acidic all along the profile (3.5 to 3.9), with fluctuations that do not depend on depth. Such evolution of the acidity throughout the guano deposit profile leads to various environmental conditions that constrain the stability of minerals (Fig. 36). The stable end-members of phosphatization are the minerals of the apatite group formed in alkaline environment buffered by the carbonate substratum, and strengite and variscite in acidic conditions. Gypsum has a quite large stability field. 


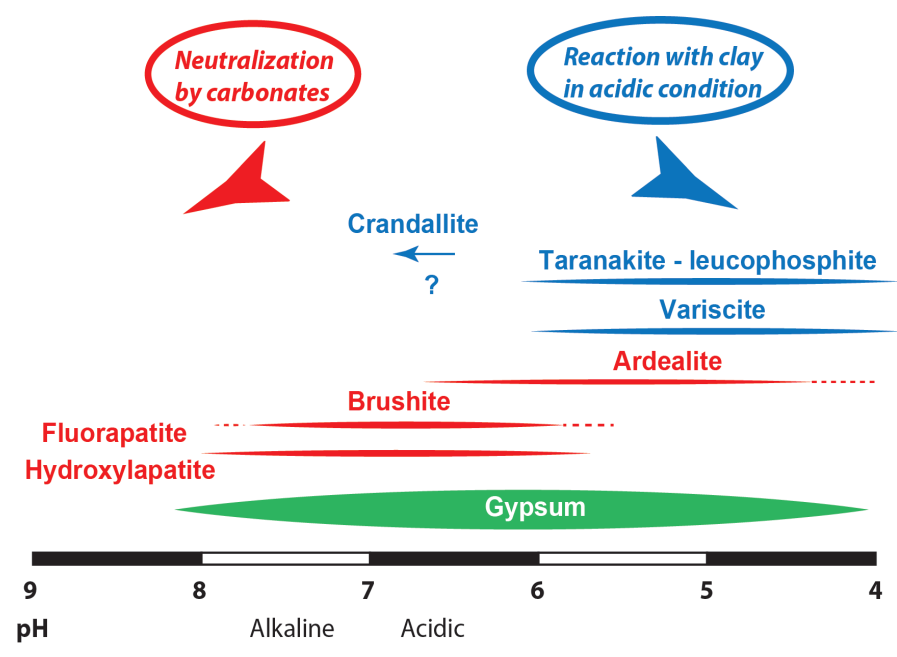

Fig. 36. Synthesis of approximate stability field of studied phosphate minerals and gypsum (after Onac \& Vereş, 2003; Shahack-Gross et al., 2003; Onac et al., 2005b; Giurgiu \& Tămaş, 2013).

\section{CONCLUSIONS}

We investigated guano-related minerals in 22 European caves located in the Slovak Republic, Hungary, France, Macedonia, and Italy. Using XRD, micro-Raman spectroscopy, and SEM, we identified 17 phosphate minerals (not considering Al-rich Strengite that is not recognized by IMA), some of them being very rare in caves, and one sulfate (gypsum). Combining $\mathrm{pH}$ and micro-climatic measurements with ${ }^{14} \mathrm{C}$ radiometric dates, we characterized some environmental parameters that control mineral genesis and the relationships between some minerals and their environment.

- On fresh decaying guano, the typical precursor mineral association is composed of brushite, ardealite, and gypsum. Such minerals are soluble and do not persist long in older guano accumulations.

- The apatite minerals (hydroxylapatite, fluorapatite) precipitate onto carbonates - limestone or calcite speleothems - by buffering of acid phosphate leachates. They generally occur as light or brown crusts on the walls and floors that can cover extensive areas. Their low solubility triggers high stability, hence the dominant abundance of this mineral association.

- The contact of acidic guano leachates with cave sediments, mainly clay and fluvial deposits and sometimes sulfides such as pyrite, allows the hydrolysis of the detrital minerals and the combination of their cations (Al, K, Fe, and Mn) with the phosphatic leachates. Taranakite, strengite, and variscite are the end-members of the mineral suites, hence the most stable and frequent minerals. However, the large amount of combinations and environmental characteristics allows the formation of rare phosphates, most of them being known only from a limited number of caves on Earth (montgomeryite, crandallite, (Al-rich) strengite, leucophosphite, vashegyite, vivianite, whitlockite, berlinite). Spheniscidite was found for the first time in caves in three of the studied sites, and robertsite is known only in three caves in the world, two of them presented in this study.

- Caves are generally wet, hence the abundance of hydrated phosphates. Less frequently, strong dehydration may produce rare minerals: guano self-combustion is suspected to be at the origin of a possible occurrence of berlinite (requiring temperatures above $570^{\circ} \mathrm{C}$ ). Gypsum may persist in especially dry environment and even at the bottom of guano accumulation with poor drainage (damp conditions).

- Acidity of a decaying guano heap is well known. We measured $\mathrm{pH}$ as low as 3.5, which can persist even in old guano deposits. The distribution of acidity controls the mineral assemblage and the stability of end-member phosphates, in acid environment or alkaline at the contact with the limestone bedrock.

- We found guano more than 6000 years old, with an accumulation covering more than 2300 years in Grosse Marguerite Cave, France. Although the continuity of this deposit is still questioned, in Raganeous Cave it appears to be as old as 1000 years.

- Most of the previous studies on phosphate minerals, including this one, have been carried out by visually-oriented sampling strategy. Future investigations, which would also benefit from the fast development of portable analytical tools, should progressively turn to more continuous analyses. First, this will allow new mineral discoveries, and second it would lead to a better understanding of the environmental parameters that control mineral genesis. Finally, the use of different biological (pollen) and chemical (stable isotope) proxies available in guano offer a great potential for paleoenvironmental and paleoclimatic reconstruction.

- Some caves, characterized by specific environmental conditions, host rock composition, sediments, sulfides, or micro-climatic conditions, may represent outstanding sites for mineral studies, and particularly for phosphates and secondary sulfates related to bat guano deposits. Corona 'e sa Craba (Sardinia) and Domica-Baradla (SlovakiaHungary), are two such examples of unique caves for their phosphate mineralogy.

\section{ACKNOWLEDGEMENTS}

We are deeply grateful to B.P. Onac and C.A. Hill for their thoughtful review that helped improving the paper. Part of this work was initiated by a FrenchCzech bilateral program PHC Barrande $n^{\circ} 33988 R L$ (PA, IB, AC, VK). It also benefited of the International Cooperation Project - Cori 2012, Dipartimento di Scienze della Terra e del Mare (DiSTeM), Università degli Studi di Palermo (PA) and of the Program "The decorated caves of the Gaztelu Hill (Saint-Martind'Arberoue, Pyrénées-Atlantiques). Study of Paleolithic art: Isturitz, Oxocelhaya-Hariztoya and Erberua" funded by the Archeology Regional Service NouvelleAquitaine, direction D. Garate. J. Benes, University of 
South Bohemia, provided funding for the radiocarbon dating of Domica guano. We are grateful to many people who participated to this work: D. Borschneck (CEREGE) and V. Heresanu (CINaM), who performed the XRD analysis; D. Garate, M. Olivares, and K. Castro (Departamento de Química Analitica, Facultad de Ciencia y Tecnología, Universidad del Pais Vasco, UPV/EHU) for the EDXRF and Raman in-situ analysis in Isturitz-Oxocelhaya caves; B.P. Onac for his help during the analysis of the Corona 'e sa Craba mineral samples and for useful discussions. For permission to cave access and help during sampling: R. Chiesa, the Archaeological Superintendency of Liguria and Toirano Municipality for access granted to the Toirano caves; Francescantonio d'Orilia, Fondazione MiDa and the cave guides for help during sampling at PertsosaAuletta cave; F. Branca and E. Amore (Riserva naturale integrale Grotta Palombara); S. Costanzo (Riserva naturale integrale Grotta Monello); R. Di Pietro (Riserva Naturale Integrale Grotta di Carburangeli); J. Darricau (Grotte d'Isturitz, Association Gaztelu); Aggtelek National Park (Baradla Cave); V. Papáč (Slovak Caves Administration, Domica Cave), O. Peyronnel (Ardèche Gorges National Reserve). For their help in the field: P. and Z. Zentay, A. Hajnal, J. Petrásek, P. Tordjman, cavers from ANS Le Taddarite of Palermo, A. Cariola., L. Catsoyannis, G. Coquin and M.-L. Madelaine, who shared with us the discovery of the Raganeous Cave. M.-C. Lankester, for information about the bat community in Raganeous Cave. C. Dodelin, who provided the ${ }^{14} \mathrm{C}$ dating result of Saint-Marcel guano and guided us in this cave and M. Faverjon for the survey. J. Medina (Univ. Valladolid), for the in-depth XRD analysis on Palombara and Raganeous samples. P. Camps (Géosciences Montpellier), for the paleomagnetic measuring of Palombara Cave samples. I.B. thanks C. Moreau and J.-P. Dumoulin of ARTEMIS AMS facility (LMC14, Saclay, France) who performed radiocarbon dates referenced as "SAC" and T. Goslar of the Poznan Laboratory for Radiometric Dating reference as "Poznan LR". We are gratefull to MISTRAL-BIODIVMEX CNRS program for participating to the funding of Poznan radiocarbon datings.

\section{REFERENCES}

Audra P., Folléas C., Gimenez B., Hof B., Hotz B. \& Sounier J.P., 2002 - Spéléologie dans les Préalpes de Grasse. Édisud, Aix-en-Provence, 180 p.

Audra P., Barriquand L. Bigot J.-Y., Cailhol D., Caillaud H., Vanara N. \& Nobécourt J.-C., 2016 - L'impact méconnu des chauves-souris et du guano dans l'évolution morphologique des cavernes. Karstologia, 68: $1-20$.

Baldoni E., De Waele J., Galli E., Messina M., Onac B.P., Sanna L., Sauro F. \& Villani M., 2013 - Mineralogy and speleogenesis of the Corona 'e sa Craba quartzite cave (Carbonia, Southwestern Sardinia). In: De Waele J., Forti P. \& Naseddu A. (Eds.), Memorie dell'Istituto Italiano di Speleologia S. II, XXVIII (Proceedings of the $2^{\text {nd }}$ International Symposium on mine caves, Iglesias, 2012), 197-210.

Bannister F. \& Bennett H., 1947 - Whitlockite from Sebdou, Oran, Algeria. Mineralogical Magazine and
Journal of the Mineralogical Society, 28: 29-30. https://doi.org/10.1180/minmag.1947.028.196.06

Bella P. \& Lalkovič M., 2001 - Jaskyña Domica. Správa slovenských jaskýn̆, Liptovský Mikuláš. Cave Domica, Slovak Cave Administration, Liptovský Mikuláš [in Slovak]. http://www.ssj.sk/en/jaskyna/7-domica-cave

Bella P., Bosák P., Braucher R., Pruner P., Hercman H., Minár J., Veselský M., Holec J. \& Léanni L., 2019 Multi-level Domica-Baradla cave system (Slovakia, Hungary): Middle Pliocene-Pleistocene evolution and implications for the denudation chronology of the Western Carpathians. Geomorphology, 327: 62-79. https://doi.org/10.1016/j.geomorph.2018.10.002

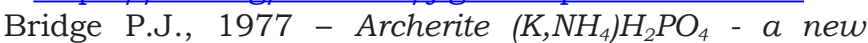
mineral from Madura, Western Australia. Mineralogical Magazine, 41: 33-35. https://doi.org/10.1180/minmag. 1977.041.317.05

Bridge P.J. \& Robinson B.W., 1983 - Niahite - a new mineral from Malaysia. Mineralogical Magazine, 47: 79-80. https://doi.org/10.1180/minmag.1983.047.342.14

Brunet P., Dupré B. \& Faverjon M. (Eds.), 2008 - La grotte de Saint-Marcel-d'Ardèche. Comité Départemental de Spéléologie de l'Ardèche, $242 \mathrm{p}$.

CAMIDA, 2018 - Cave Mineral Database. http://caveminerals.rc.usf.edu

Chang S.J., Blake R.E., Stout L.M. \& Kim S.J., 2010 - Oxygen isotope, micro-textural and molecular evidence for the role of microorganisms in formation of hydroxylapatite in limestone caves, South Korea. Chemical Geology, 276: 209-224.

https://doi.org/10.1016/j.chemgeo.2010.06.007

Cleary D.M., Wynn J.G., Ionita M., Forray F.L. \& Onac B.P., 2017 - Evidence of long-term NAO influence on East-Central Europe winter precipitation from a guanoderived $\delta^{15} N$ record. Scientific Reports, 7: 14095. https://doi.org/10.1038/s41598-017-14488-5

Créac'h Y., 1967 - Inventaire spéléologique des AlpesMaritimes. Fédération Française de Spéléologie \& Bureau de recherches géologiques et minières, Orléans, tome II, $350 \mathrm{p}$.

D’Angeli I.M., Carbone C., Nagostinis M., Parise M., Vattano M., Madonia G. \& De Waele J., 2018 - New insights on secondary minerals from Italian sulfuric acid caves. International Journal of Speleology, 47 (3): 271 291. https://doi.org/10.5038/1827-806X.47.3.2175

De Vivo A., Piccini L, Forti P. \& Badino G., 2013 - Some scientific features of Puerto Princesa Underground River (Palawan, Philippines). In: Filippi M. \& Bosak P. (Eds.), Proceedings of the $16^{\text {th }}$ International Congress of Speleology, Brno, 3: 35-41.

http://www.speleogenesis.info/directory/karstbase/ pdf/seka pdf13563.pdf

De Waele J., Audra P., Madonia G., Vattano M., Plan L., D’Angeli I.M., Bigot J.-Y. \& Nobécourt J.C., 2016 - Sulfuric acid speleogenesis (SAS) close to the water table: Examples from southern France, Austria, and Sicily. Geomorphology, 253: 452-467. https://doi.org/10.1016/j.geomorph.2015.10.019

Di Maggio C., Madonia G., Parise M. \& Vattano M., 2012 - Karst of Sicily and its conservation. Journal of Cave and Karst Studies, 74 (2): 157-172. https://doi.org/10.4311/2011JCKS0209

Di Stefano P., Renda P., Zarcone G., Nigro F. \& Cacciatore M., 2013 - Carta geologica d'Italia alla scala 1: 50.000 e note illustrative del Foglio 619, Santa Margherita di Belice. Roma: ISPRA, Servizio Geologico d'Italia. http://www.isprambiente.gov.it/Media/carg/note illustrative/619 S Margherita di Belice.pdf 
Dutton A., Scicchitano G., Monaco C., Desmarchelier J.M., Antonioli F., Lambeck K., Esat T.M., Fifield L.K., McCulloch M.T. \& Mortimer G., 2009 - Uplift rates defined by U-series and ${ }^{14} \mathrm{C}$ ages of serpulid-encrusted speleothems from submerged caves near Siracusa, Sicily (Italy). Quaternary Geochronology, 4: 2-10. https://doi.org/10.1016/j.quageo.2008.06.003

Forti P., 2001 - Biogenic speleothems: an overview. International Journal of Speleology, 30: 39-56. https://doi.org/10.5038/1827-806X.30.1.4

Forti P., Galli E. \& Rossi A., 2000 - Mineraligeneticamente correlati al guano in una grotta naturale dell'Albania. Primo contributo. Le Grotte d'Italia, V (1): 45-59.

Frost R. \& Palmer S.J., 2011 - Thermal stability of the 'cave' mineral brushite $\mathrm{CaHPO}_{4} \cdot 2 \mathrm{H}_{2} \mathrm{O}-$ Mechanism of formation and decomposition. Thermochimica Acta, 521 (1-2): 14-17.

https://doi.org/10.1016/j.tca.2011.03.035

Frost R.L., Palmer S.J. \& Pogson R.E., 2011 - Raman spectroscopy of newberyite $\mathrm{Mg}\left(\mathrm{PO}_{3} \mathrm{OH}\right) \cdot 3 \mathrm{H}_{2} \mathrm{O}:$ A cave mineral. Spectrochimica Acta Part A: Molecular and Biomolecular Spectroscopy, 79 (5): 1149-1153. https://doi.org/10.1016/j.saa.2011.04.035

Frost R.L., Palmer S.J. \& Pogson R.E., 2012 - Thermal stability of crandallite $\mathrm{CaAl}_{3}\left(\mathrm{PO}_{4}\right)_{2}(\mathrm{OH})_{5} \cdot\left(\mathrm{H}_{2} \mathrm{O}\right)$ a 'Cave' mineral from the Jenolan Caves. Journal of Thermal Analysis and Calorimetry, 107 (3): 905-909. https://doi.org/10.1007/s10973-011-1578-6

Fulco A., Vattano M., Valenti P., Madonia G. \& Lo Valvo M., 2015 - The bat fauna of four cavities in south-west Sicily: microclimatic analysis and phenology of communities. III Convegno Italiano sui Chirotteri, Trento, Abstracts, 30. Gruppo Italiano Ricerca Chirotteri, Roma. http://www.pipistrelli.net/drupal/system/files/ GIRC2015 complete.pdf

Gaál F. \& Vlček L., 2011 - Tektonická stavba jaskyne DOMICA (Slovenský kras) Tectonic structure of cave Domica (Slovak Karst). Aragonit, 16 (1-2): 3-11 [in Slovak with English abstract].

http://www.ssj.sk/sk/user files/Aragonit16 komplet.pdf

Gallay M., Kaňuk J., Hochmuth Z., Meneely J.D., Hofierka J. \& Sedlák V., 2015 - Large-scale and high-resolution 3-D cave mapping by terrestrial laser scanning: a case study of the Domica Cave, Slovakia. International Journal of Speleology, 44 (3): 277-291. https://doi.org/10.5038/1827-806X.44.3.6

Garate D., Labarge A., Rivero O., Normand C. \& Darricau J., 2013 - The cave of Isturitz (West Pyrenees, France): one century of research in Paleolithic parietal art. Arts, 2 (4): 253-272.

https://doi.org/10.3390/arts2040253

Giurgiu A. \& Tămaş T., 2013 - Mineralogical data on bat guano deposits from three Romanian caves. Studia UBB Geologia, 58 (2): 13-18. https://doi.org/10.5038/1937-8602.58.2.2

Goldberg P. \& Nathan Y., 1975 - The phosphate mineralogy of et-Tabun cave, Mount Carmel, Israel. Mineralogical Magazine, 40: 253-258.

https://doi.org/10.1180/minmag.1975.040.311.06

Grassa F., Capasso G., Favara R. \& Inguaggiato S., 2006 - Chemical and isotopic composition of waters and dissolved gases in some thermal springs of Sicily and adjacent volcanic islands, Italy. Pure and Applied Geophysics, 163: 781-807.

https://doi.org/10.1007/s00024-006-0043-0

Hill C.A., 1999 - Mineralogy of Kartchner Caverns, Arizona. Journal of Cave and Karst Studies, 61 (2): 73-78. https://caves.org/pub/journal/PDF/V61/v61n2-HillMineralogy.pdf
Hill C.A. \& Forti P., 1997 - Cave minerals of the world ( $2^{\text {nd }}$ Ed.). National Speleological Society, Huntsville, Alabama, 464 p.

Karkanas P., Rigaud J.P., Simek J.F., Albert R.M. \& Weiner S., 2002 - Ash bones and guano: a study of the minerals and phytoliths in the sediments of Grotte XVI, Dordogne, France. Journal of Archaeological Science, 29 (7): 721-732. https://doi.org/10.1006/jasc.2001.0742

Kaye C.A., 1959 - Geology of Isla Mona, Puerto Rico, and notes on the age of Mona Passage. U.S. Geological Survey Professional Paper, 317-C: 141-178.

https://doi.org/10.3133/pp317C

Kereskényi E., 2014 - A Baradla-Domica-barlangrendszer ásványtani vizsgálata különös tekintettel a foszfátokra; valamint a guanóból származtatható foszfátok terhelése a barlangi környezetre (The Baradla cave mineralogical examination of the particular phosphates, as well as phosphates derived from guano of the cave environment). Master Sc. Dipl. Thesis, University Miskolc, 85 p.

Kettner R., 1948 - O netopyrim guanu a guanovych korosich $v$ jeskynie Domici (The Baradla cave mineralogical examination of the particular phosphates, as well as phosphates derived from guano of the cave environment). Sbornik Státního geologického ústavu, Praha, XV, p. 41-64.

Kováč L., Elhottová D., Mock A., Nováková A., Krištůfek V., Chroňáková A., Lukešová A., Mulec J., Košel V., Papáč V., Luptáčik P., Uhrin M., Višňovská Z., Hudec I., Gaál L. \& Bella P., 2014 - The cave biota of Slovakia. State Nature Conservancy SR, Slovak Cave Administration, Liptovský Mikuláš, 192 p.

https://www.researchgate.net/ publication/269106565_The_cave_biota_of_Slovakia

Krištůfek V., Elhottová D., Kováč L., Chroňáková A., Žák K. \& Světlík I., 2008 - Stáři kopy netopýř́ho guána $v$ jeskyni Domica (NP Slovenský Kras) a elektronová mikroskopie exkrementů netopýrü (The age of bat guano heap in Domica Cave (Slovak Karst NP) and electron microscopy of bat excrements. Slovenský Kras - Acta Carsologica Slovaca, 46: 165-172.

https://issuu.com/dankez/docs/slovenskykras 1-2008

Lentini F. \& Carbone S., 2014 - Geologia della Sicilia. Memoria descrittive della Carta Geologica d'Italia, 95: 1-413 + map. ISPRA.

Madonia G., Frisia S., Borsato A. Macaluso T., Mangini A., Paladini M., Piccini L., Miorandi R., Spötl C., Sauro U., Agnesi V., Di Pietro R., Palmeri A. \& Vattano M., 2003 - La Grotta di Carburangeli ricostruzione climatica dell'Olocene per la piana costiera della Sicilia nordoccidentale. Studi Trentini di Scienze Naturali, Acta Geologica, 80: 153-167. http://www2.muse.it/pubblicazioni/6/actaG80/Vol ACTA_80_2003_153-167.pdf

Marincea Ş. \& Dumitraş D.G., 2005 - First reported sedimentary occurrence of berlinite $\left(\mathrm{AlPO}_{4}\right)$ in phosphatebearing sediments from Cioclovina Cave, Romania. American Mineralogist, 90 (7): 1203-1208. https://doi.org/10.2138/am.2005.418

Marincea SS., Dumitraş D. \& Gibert R., 2002 - Tinsleyite in the "dry" Cioclovina Cave (Sureanu Mountains, Romania). European Journal of Mineralogy, 14 (1): 157-164.

https://doi.org/10.1127/0935-1221/2002/0014-0157

Marincea S.., Dumitraş D-G., Diaconu G. \& Essaid B., 2004a - Hydroxylapatite, brushite and ardealite in the bat guano deposit from Peştera Mare de la Mereşti, Perşani Mountains, Romania. Neues Jahrbuch fur Mineralogie-Monatshefte, 10: 464-488. https://doi.org/10.1127/0028-3649/2004/2004-0464 
Martini J.E.J., 1993 - A concise review of the cave mineralogy of Southern Africa. Proceedings of the $11^{\text {th }}$ International Congress of Speleology, Beijing, China, p. $72-75$.

Martini J.E.J., 1996 - Contribution to the mineralogy of the Caves of the Gcwihaba Hills, North-Western Botswana. Bulletin of the South African Speleological Association, 36: 14-18.

Martini J.E.J., 2000 - La grotte et le karst de Cango, Afrique du Sud. Karstologia, 36: 43-54.

https://doi.org/10.3406/karst.2000.1751

Messana E., 1994 - Il sistema carsico del gruppo montuoso di M. Inici (Castellammare del Golfo, TP). Bollettino Accademia Gioenia Scienze Natutali, 27 (348): 547-562.

Mocochain L., Bigot J.-Y., Clauzon G., Faverjon M. \& Brunet P., 2006 - La grotte de Saint-Marcel (Ardèche): un référentiel pour l'évolution des endokarsts méditerranéens depuis $6 \mathrm{Ma}$. Karstologia, 48: 33-50. https://doi.org/10.3406/karst.2006.2587

Mocochain L., Audra P. \& Bigot J.-Y., 2011 - Base level rise and per ascensum model of speleogenesis (PAMS). Interpretation of deep phreatic karsts, vauclusian springs and chimney-shafts. Bulletin de la Société Géologique de France, 182 (2): 87-93.

https://doi.org/10.2113/gssgfbull.182.2.87

Muraoka Y. \& Kihara, 1997 - The temperature dependence of the crystal structure of berlinite, a quartz-type form of $\mathrm{AlPO}_{4}$. Physics and Chemistry of Minerals, 24 (4): 243253. https://doi.org/doi.org/10.1007/s002690050036

Nemoz M., 2008 - Conservation de trois Chiroptères cavernicoles dans le Sud de la France. Final report LIFE 04NAT/FR/000080, SFEPM, Castanet-Tolosan, 120 p. http://www.sfepm.org/LifeChiropteres/images2/ Resultats\%20life/rapport_final_08.pdf

Onac B.P., 1996 - Mineralogy of speleothems from caves in the Padurea Craiului Mountains (Romania), and their palaeoclimatic significance. Cave and Karst Science, 23 (3): 109-120.

Onac B.P., 2012 - Minerals. In: Culver D.C. \& White W.B. (Eds.), Encyclopedia of caves (2 ${ }^{\text {nd }}$ Ed.). Elsevier, New York, p. 499-508.

https://doi.org/10.1016/B978-0-12-383832-2.00072-4

Onac B.P., 2019 - Cave discovered by mining activities and mined caves. In: Ponta G.M.L. \& Onac B.P. (Eds.), Cave and karst systems of Romania. Springer International, Cham, p. 475-483.

https://doi.org/10.1007/978-3-319-90747-5 54

Onac B.P. \& Forti P., 2011a - State of the art and challenges in cave minerals studies. Studia UBB Geologia, 56 (1): 33-42.

https://doi.org/10.5038/1937-8602.56.1.4

Onac B.P. \& Forti P., $2011 \mathrm{~b}-$ Minerogenetic mechanisms occurring in the cave environment: an overview. International Journal of Speleology, 40 (2): 79-98. https://doi.org/10.5038/1827-806X.40.2.1

Onac B.P. \& Effenberger H.S., 2007 - Re-examination of berlinite $\left(\mathrm{AlPO}_{4}\right)$ from the Cioclovina Cave, Romania. American Mineralogist, 92 (11-12): 1998-2001.

https://doi.org/10.2138/am.2007.2581

Onac B.P. \& Veress D.S., 2003 - Sequence of secondary phosphates deposition in a karst environment: evidence from Māgurici Cave (Romania). European Journal of Mineralogy, 15: 741-745.

https://doi.org/10.1127/0935-1221/2003/0015-0741

Onac B.P. \& White W.B., 2003 - First reported sedimentary occurrence of berlinite $\left(\mathrm{AlPO}_{4}\right)$ in phosphate-bearing sediments from Cioclovina Cave, Romania. American Mineralogist, 88 (8-9): 1395-1397.

https://doi.org/10.2138/am.2005.418
Onac B.P., Kearns J., Breban R. \& Cîntă Pânzaru S., 2004 - Variscite $\left(\mathrm{AlPO}_{4} \cdot 2 \mathrm{H}_{2} \mathrm{O}\right)$ from Cioclovina Cave (Sureanu Mountains, Romania): a tale of a missing phosphate. Studia UBB Geologia, 49 (1): 3-14.

https://doi.org/10.5038/1937-8602.49.1.1

Onac B.P., Ettinger K., Kearns J. \& Balasz I.I., 2005a - A modern, guano-related occurrence of foggite, $\mathrm{CaAl}\left(\mathrm{PO}_{4}\right)$ $(\mathrm{OH})_{2} \cdot \mathrm{H}_{2} \mathrm{O}$ and churchite-(Y), $\mathrm{YPO}_{4} \cdot 2 \mathrm{H}_{2} \mathrm{O}$ in Cioclovina Cave, Romania. Mineralogy and Petrology, 85 (3-4): 291302. https://doi.org/10.1007/s00710-005-0106-4

Onac B.P., Fornós J.J., Ginés A. \& Ginés J., 2005b Mineralogical reconnaissance of caves from Mallorca Island. Endins, 27: 131-140.

http://www.raco.cat/index.php/Endins/article/ view/122521/169644

Onac B.P., Effenberger H., Ettinger K. \& Cinta Panzaru S., 2006a - Hydroxylellestadite from Cioclovina Cave (Romania): Microanalytical, structural, and vibrational spectroscopy data. American Mineralogist, 91 (11-12): 1927-1931.

https://doi.org/10.2138/am.2006.2143

Onac B.P., Zaharia L., Kearns J. \& Vereş D., 2006b - Vashegyite from Gaura cu Muscă Cave (Locvei Mountains, Romania): a new and rare phosphate occurrence. International Journal of Speleology, 35 (2): 67-73. https://doi.org/10.5038/1827-806X.35.2.2

Onac B.P., Sumrall J., Mylroie J.E. \& Kearns J., 2009 Cave minerals of San Salvador Island, Bahamas. The University of South Florida Karst Studies Series, 1, 70 p. http://plantphys.info/bahamas/copyright/onac.pdf

Onac B.P., Forray F.L., Wynn J.G. \& Giurgiu A.M., 2014 - Guano-derived $\delta^{13} \mathrm{C}$-based paleo-hydroclimate record from Gaura cu Musca Cave, SW Romania. Environmental Earth Sciences, 71 (9): 4061-4069. https://doi.org/10.1007/s12665-013-2789-x

Onac B.P., Hutchison S.M., Geanta A., Forray F.L., Wynn J.G., Giurgiu A.C. \& Coroiu I., 2015 - A 2500year Late Holocene multi-proxy record of vegetation and hydrologic changes from a cave guano-clay sequence in SW Romania. Quaternary Research, 83: 437-448.

https://doi.org/10.1016/j.yqres.2015.01.007

Ország G., Vid Ö., Szilágyi F., Végh Z. \& Gyuricza G., 1989 - Baradla-barlang. 1:10000. Magyar Karszt és Barlangkutató Társulat és a KPVDSZ Vörös Meteor Természetbarát Egyesület, Budapest.

Peréz Martínez J.J. \& Wiggen R.W., 1953 - Los depositos de fosforitas de Salsimas Hidalgo y Ayancual, Estado de Nuevo León. México Instituto Nacional para la Investigacion de Recursos Minerales Boletin, 32: 1-33.

Pogson R.E., Osborne R.A.L., Colchester D.M. \& Cendón D.I., 2011 - Sulfate and phosphate speleothems at Jenolan Caves, New South Wales, Australia. Acta Carsologica, 40 (2): 239-254.

https://doi.org/10.3986/ac.v40i2.9

Prieto N., Carrero J.A., Olivares M. \& Madariaga Mota J.M., 2015 - Forme sobre medidas in situ mediante espectroscopia RAMAN y EDXRF en la cueva de Isturitz. In: Garate D., Darricau J., Labarge A., Normand C. \& Rivero O. (Eds.), Les grottes ornées de la colline de Gaztelu (Saint-Martin-d'Arberoue, PyrénéesAtlantiques). Étude de l'art pariétal Paléolithique: Isturitz, Oxocelhaya-Hariztoya et Erberua, Service régional de l'archéologie d'Aquitaine, p. 287-294.

Puşcaş C.M., Kristaly F., Stremțan C.C., Onac B.P. \& Effenberger H.S., 2014 - Stability of cave phosphates: case study from Liliecilor Cave (Trascău Mountains, Romania). Neues Jahrbuch fur MineralogieAbhandlungen (J. Min. Geochem.), 19 (1-2): 157-168. https://doi.org/10.1127/0077-7757/2014/0254 
Reynaud A., 2000 - Fonctionnement d'un aquifère karstique décollé sur une semelle de Trias évaporitique, exemple du massif du mont Vial (Arc de Castellane, Alpes-Maritimes). Thesis, Université de FrancheComté, Besançon, 246 p.

Reimer P.J., Bard E., Bayliss A., Beck J.W., Blackwell P.G., Ramsey C.B., Buck C.E., Cheng H., Edwards R.L., Friedrich M., Grootes P.M., Guilderson T.P., Haflidason H., Hajdas I., Hatté C., Heaton T.J., Hogg A.G., Hughen K.A., Kaiser K.F., Kromer B., Manning S.W., Niu M., Reimer R.W., Richards D.A., Scott E.M., Southon J.R., Turney C.S.M. \& van der Plicht J., 2013 - IntCal13 and MARINE13 radiocarbon age calibration curves $0-50000$ years cal BP. Radiocarbon, 55 (4): 1869-1887. https://doi.org/10.2458/azu js rc.55.16947

Ruggieri R. (Ed.), 2000 - Il carsismo negli Iblei e nell'area sud mediterranea. Atti del 1 Seminario, Ragusa 1999. Speleologia Iblea, Centro Ibleo di Ricerche SpeleoIdrologiche, Ragusa, 8: 1-242.

Santo A., 1988 - Alcune osservazioni sul carsismo ipogeo dei M. Alburni. L'Appennino Meridionale, Annuario CAI sez. Napoli, p. 71-88.

Sauro F., De Waele J., Onac B.P., Galli E., Dublyansky Y., Baldoni E. \& Sanna L., 2014 - Hypogenic speleogenesis in quartzite: the case of Corona 'e Sa Craba Cave (SW Sardinia, Italy). Geomorphology, 211: 77-88.

https://doi.org/10.1016/j.geomorph.2013.12.031

Schadler J., 1932 - Ardealit, ein neues Mineral $\mathrm{CaHPO}_{4} \mathrm{CaSO}_{4}+4 \mathrm{H}_{2} \mathrm{O}$. Central-blatt Minealogie Abt. A., 40-41.

Shahack-Gross R., Berna F., Karkanas P. \& Weiner S., 2004 - Bat guano and preservation of archaeological remains in cave sites. Journal of Archaeological Science, 31: 1259-1272.

https://doi.org/10.1016/j.jas.2004.02.004

Stuiver M. \& Reimer P.J., 1993 - Extended ${ }^{14} \mathrm{C}$ data base and revised $C A L I B$ 3.0 ${ }^{14} \mathrm{C}$ age calibration program. Radiocarbon, 35 (1): 215-230.

https://doi.org/10.1017/S0033822200013904
Temovski M., 2013 - Phantom speleogenesis in a thermal environment. $21^{\text {st }}$ International Karstological School "Hypogene speleogenesis", 10-14.06.2013, Postojna, Slovenia.

Temovski M., 2016 - Evolution of karst in the lower part of Crna Reka river basin. Springer Theses. Springer International Publishing, Cham, $265 \mathrm{p}$.

https://www.springer.com/us/book/9783319245454

Theodorou G., Barlas K. \& Stathopoulou E., 2004 - On the presence of the mineral vivianite in the sediments of the "Megali Grava" cave in Loutses (Corfu, Greece). Annales géologiques des pays helléniques, XL (A): 133-142.

Vanara N., 2015 - Karstologie de la colline de Gatzelu. In: Garate D., Darricau J., Labarge A., Normand C. \& Rivero O. (Eds.), Les grottes ornées de la colline de Gaztelu (Saint Martin d'Arberoue, Pyrénées-Atlantiques). Étude de l'art pariétal paléolithique. Isturitz, OxocelhayaHariztoya et Erberua, Service régional de l'archéologie d'Aquitaine, p. 263-305.

Vattano M., Scopelliti G., Fulco A., Presti R., Sausa L., Valenti P., Di Maggio C., Lo Valvo M. \& Madonia G., 2015 - La Grotta dei Personaggi di Montevago (AG), una nuova segnalazione di cavità ipogenica in Sicilia. In: De Nitto L., Maurano F. \& Parise M. (Eds.), Atti del XXII Congresso Nazionale di Speleologia, Pertosa-Auletta (SA), 30/05-02/06/2015. Memorie dell'Istituto Italiano di Speleologia, II (29): 295-300. http:/ / hdl.handle.net/10447/132894

Vattano M., Madonia G., Audra P., D’Angeli I.M., Galli E., Bigot J.-Y., Nobécourt J.-C. \& De Waele J., 2017 Update on the hypogenic caves of Sicily. In: Klimchouk A., Palmer A.N., Audra P., De Waele J., Auler A. (Eds.), Hypogene karst regions and caves of the world. Springer, New York, p. 199-209. https://doi.org/10.1007/978-3-319-53348-3 12

Yoshimura K., Urata K., Someya T. \& Akiyoshi-Do Cave Research Group, 1989 - The role of bat guano in the formation of some mineral deposits in limestone caves. Journal of the Speleological Society of Japan, 14: 40-50. 